Prepared in cooperation with the Little River Water-Quality Consortium

\title{
Multiple-Source Tracking: Investigating Sources of Pathogens, Nutrients, and Sediment in the Upper Little River Basin, Kentucky, Water Years 2013-14
}

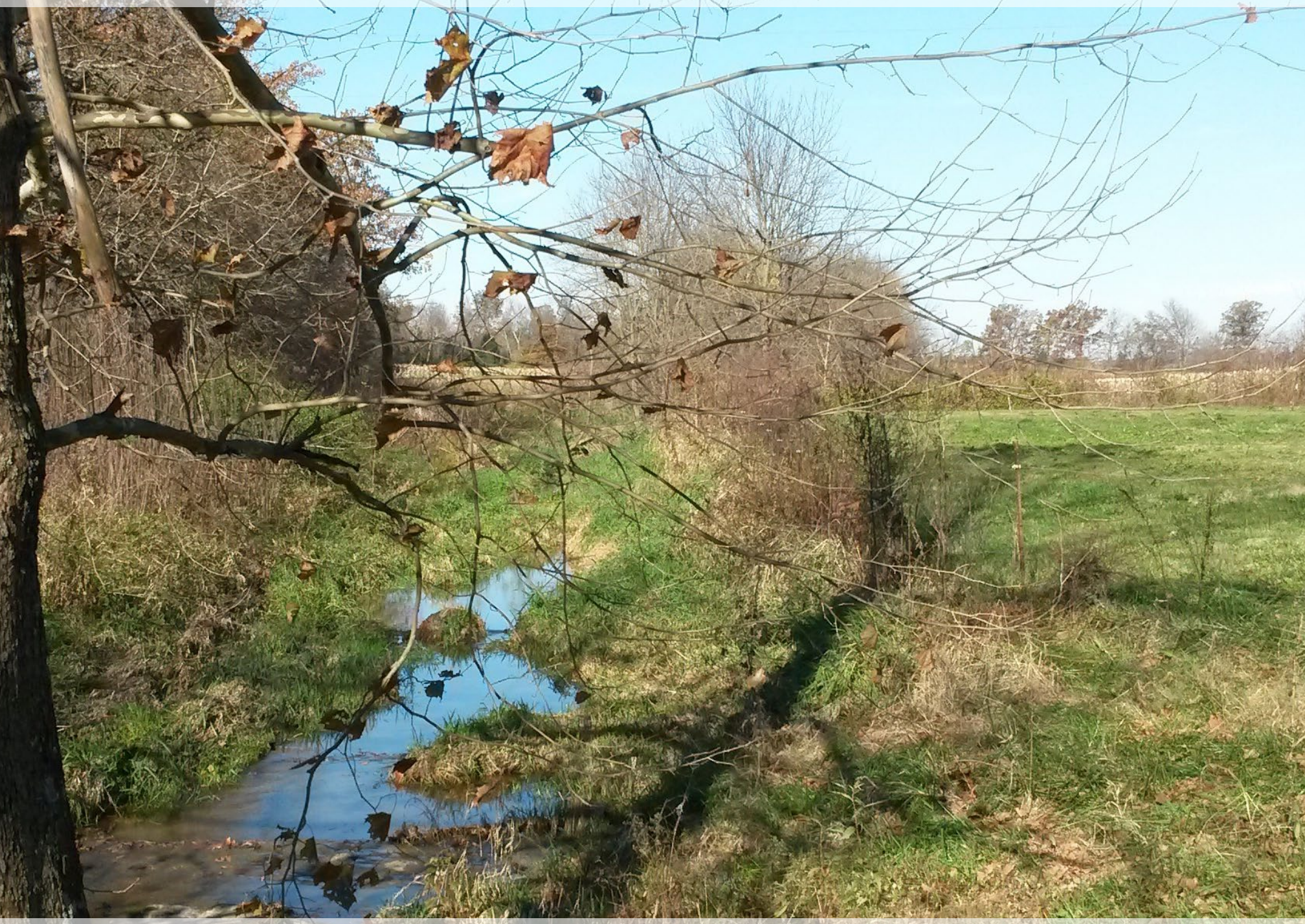

Scientific Investigations Report 2017-5086 
Cover. Unnamed tributary upstream from Kentucky Route 508, Christian County, Kentucky (photograph by Mac A. Cherry). 


\section{Multiple-Source Tracking: Investigating Sources of Pathogens, Nutrients, and Sediment in the Upper Little River Basin, Kentucky, Water Years 2013-14}

By Angela S. Crain, Mac A. Cherry, Tanja N. Williamson, and Aubrey R. Bunch

Prepared in cooperation with the Little River Water-Quality Consortium

Scientific Investigations Report 2017-5086 


\title{
U.S. Department of the Interior \\ RYAN K. ZINKE, Secretary
}

\section{U.S. Geological Survey William H. Werkheiser, Acting Director}

\author{
U.S. Geological Survey, Reston, Virginia: 2017
}

For more information on the USGS - the Federal source for science about the Earth, its natural and living resources, natural hazards, and the environment-visit https://www.usgs.gov or call 1-888-ASK-USGS.

For an overview of USGS information products, including maps, imagery, and publications, visit https://store.usgs.gov.

Any use of trade, firm, or product names is for descriptive purposes only and does not imply endorsement by the U.S. Government.

Although this information product, for the most part, is in the public domain, it also may contain copyrighted materials as noted in the text. Permission to reproduce copyrighted items must be secured from the copyright owner.

Suggested citation:

Crain, A.S., Cherry, M.A., Williamson, T.N., and Bunch, A.R., 2017, Multiple-source tracking-Investigating sources of pathogens, nutrients, and sediment in the Upper Little River Basin, Kentucky, water years 2013-14: U.S. Geological Survey Scientific Investigations Report 2017-5086, 60 p., https://doi.org/10.3133/sir20175086.

ISSN 2328-0328 (online) 


\section{Acknowledgments}

Sincere appreciation is extended to the landowners who provided us with access to many of the study sites. Cooperation from the members of the Little River Water-Quality Consortium (LRWOC) was instrumental for better understanding each basin and for gaining access to study sites. Members of the LRWOC included those in industry, different agencies, and basin stakeholders who have concerns about water-quality issues and work to improve and protect water quality in the Little River Basin. We are indebted to the many field technicians, hydrologists, and research hydrologists who have contributed to the collection of field samples and other technical content used throughout the report. Technical reviews by Kenneth Hyer and Eric Christensen of the U.S. Geological Survey substantially strengthened this report. 



\section{Contents}

Acknowledgments .......................................................................................................................ii

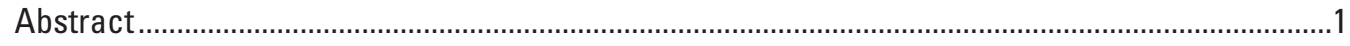

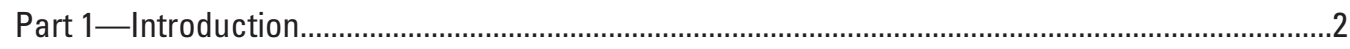

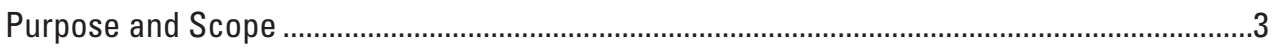

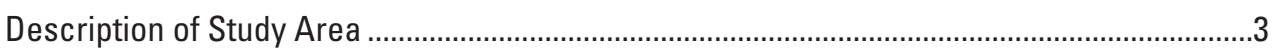

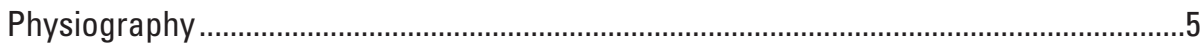

Geology

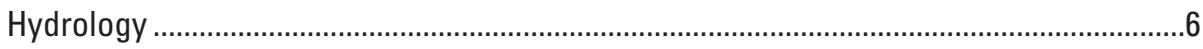

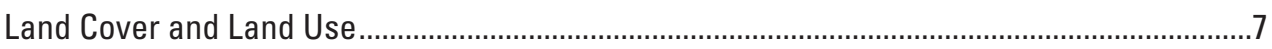

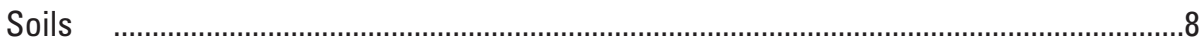

Source Inputs of Nitrogen and Phosphorus..................................................................

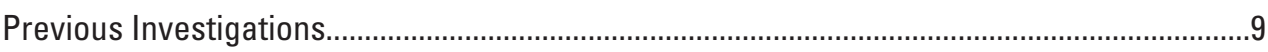

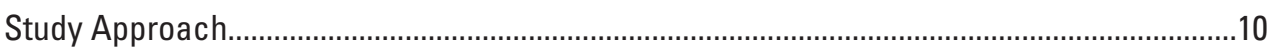

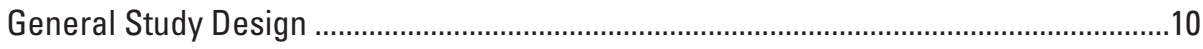

Selection of Sampling Sites .......................................................................................

Quality Assurance..........................................................................................................

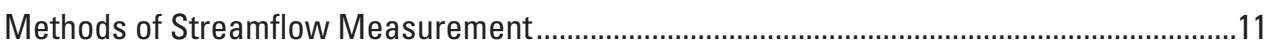

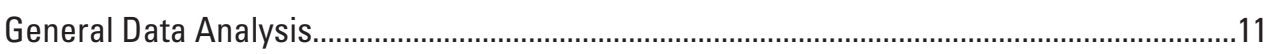

Part 2-Microbiological Water-Quality and Source Assessment.................................................12

Collection and Laboratory Analysis of E. coli Samples ......................................................12

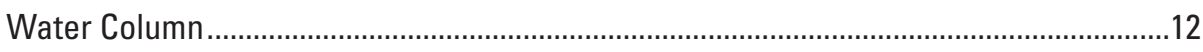

Fluvial Sediments ................................................................................................ 12

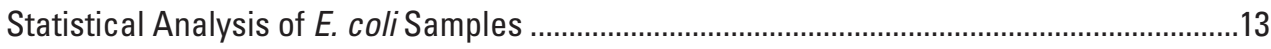

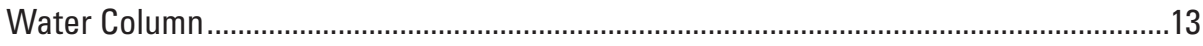

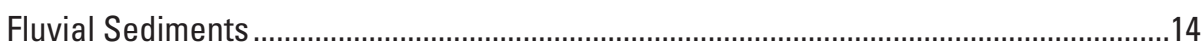

Collection and Laboratory Analysis of Bacteroidales Genetic Markers..................................14

Statistical Analysis of Bacteroidales Genetic Markers ..........................................................14

Results of Microbiological Water Quality ...............................................................................

E. coli in Water and Fluvial Sediments .............................................................................14

Bacteroidales Genetic Markers......................................................................................17

Limitations of Using Bacteroidales Genetic Markers...........................................................2

Part 3-Nutrient Water Quality and Nitrate-Source Assessment ................................................23

Collection and Laboratory Analysis of Nutrients, Suspended Sediment, and

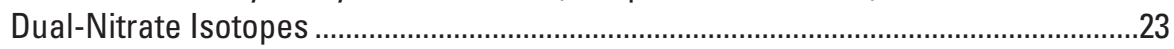

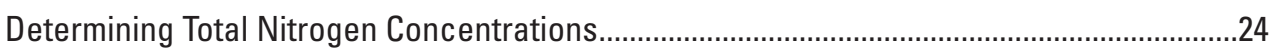

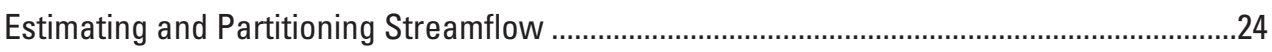

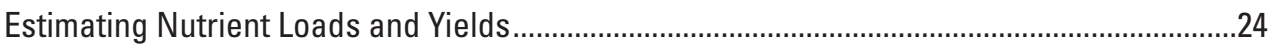

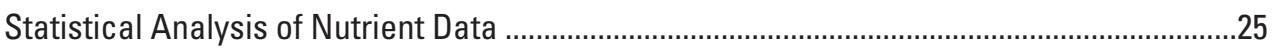

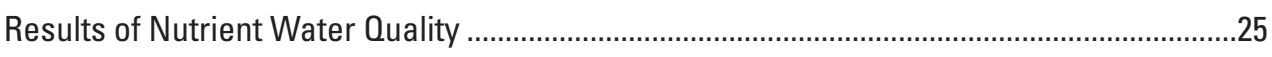

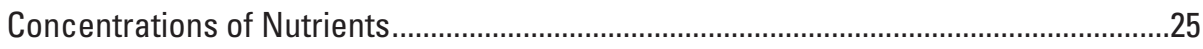

Concentrations of Nutrients at Sites NF02, SF09, and SF14 ..........................................34

Estimated Loads and Yields of Select Nutrients at Sites NF02, SF09, and SF14 ............35 
Results of Dual-Nitrate Isotopes ........................................................................................

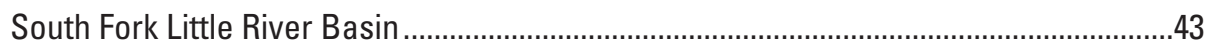

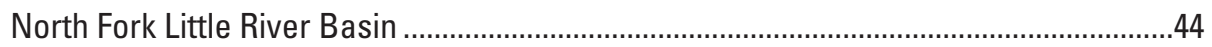

Part 4-Suspended-Sediment Source Assessment Using Sediment Fingerprinting ......................47

Collection and Laboratory Analysis of Sediment-Source and Fluvial-Target

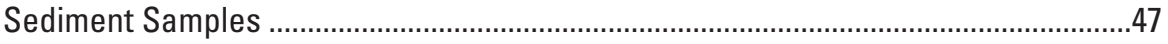

Statistical Analyses of Sediment Fingerprinting Data .............................................................

Source Inputs of Suspended Sediment ........................................................................50

Limitations Using Sediment Fingerprinting ...................................................................

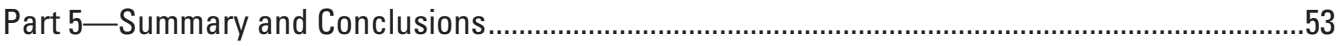

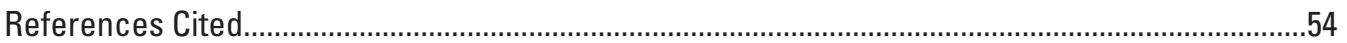

\section{Figures}

1. Map showing location of the surface-water sampling sites and karst topography in the North Fork Little River, South Fork Little River, and Little River Basins, Kentucky, water years 2013-14

2. Map showing U.S. Environmental Protection Agency Level IV Ecoregions in the North Fork Little River, South Fork Little River, and Little River Basins, Kentucky.

3. Map showing generalized geologic formations in the North Fork Little River, South Fork Little River, and Little River Basins, Kentucky...

4. Map showing land use in the South Fork Little River, North Fork Little River, and Little River Basins, Kentucky

5. Map showing distribution of $E$. coli densities in water samples at 19 sampling sites in the North Fork Little River, South Fork Little River, and Little River Basins, Kentucky, water years 2013-14

6. Boxplot showing median densities of $E$. coli in water at the 19 sampling sites throughout the Little River Basin, water years 2013-14.

7. Map showing median E. colidensity in fluvial sediment at the 19 sampling sites throughout the Little River Basin, water years 2013-14.

8. Photograph showing sewage overflow in the North Fork Little River as seen in Hopkinsville, Kentucky, approximately 0.25 mile downstream from the overflow site ...21

9. Photograph of cow standing in the South Fork Little River near Hopkinsville, Kentucky.

10. Duration curve of daily streamflow and sample flow exceedances at five sites, Little River Basin, Kentucky, water years 2013-14..

11. Boxplots showing concentrations of $A$, ammonia, $B$, ammonia plus organic nitrogen, $C$, nitrite plus nitrate, and $D$, total nitrogen at all sampling sites in the North Fork Little River, South Fork Little River, and Little River Basins, Kentucky, water years 2013-14.

12. Map showing median concentrations of total nitrogen at the 19 sampling sites in the North Fork Little River, South Fork Little River, and Little River Basins, Kentucky, water years 2013-14.

13. Map showing median concentrations of ammonia at the 19 sampling sites in the North Fork Little River, South Fork Little River, and Little River Basins, Kentucky, water years 2013-14. 
14. Map showing median concentrations of ammonia plus organic nitrogen at the 19 sampling sites in the North Fork Little River, South Fork Little River, and Little River Basins, Kentucky, water years 2013-14..

15. Map showing median concentrations of nitrite plus nitrate at the 19 sampling sites in the North Fork Little River, South Fork Little River, and Little River Basins, Kentucky, water years 2013-14.

16. Boxplots showing concentrations of $A$, orthophosphorus and $B$, total phosphorus in the North Fork Little River, South Fork Little River, and Little River Basins, Kentucky, water years 2013-14.

17. Map showing median concentrations of total phosphorus at the 19 sampling sites in the North Fork Little River, South Fork Little River, and Little River Basins, Kentucky, water years 2013-14.

18. Map showing median concentrations of orthophosphorus at the 19 sampling sites in the North Fork Little River, South Fork Little River, and Little River Basins, Kentucky, water years 2013-14.

19. Graphs showing the relation between concentrations of nitrogen species and $A$, streamflow and $B$, time, and concentrations of phosphorus species and $C$, streamflow and $D$, time for the North Fork Little River sampling station NF02, water years 2013-14, Kentucky.

20. Graphs showing the relation between concentrations of nitrogen species and $A$, streamflow and $B$, time, and concentrations of phosphorus species and $C$, streamflow and $D$, time for the South Fork Little River sampling station SF09, water years 2013-14, Kentucky.

21. Graphs showing the relation between concentrations of nitrogen species and $A$, streamflow and $B$, time; and concentrations of phosphorus species and $C$, streamflow and $D$, time, for the South Fork Little River sampling station SF14, water years 2013-14, Kentucky.

22. Graph showing relation between delta oxygen-18 and delta nitrogen-15 values with literature values of potential nitrate sources, from surface-water samples collected from the South Fork Little River Basin, Kentucky, water years 2013-14.........43

23. Graphs showing relation between $A$, delta oxygen-18 and delta nitrogen-15 values with literature values of potential nitrate sources; and $B$, delta nitrogen- 15 values and nitrate concentrations, from surface-water samples collected from the South Fork Little River Basin, Kentucky, water years 2013-14.

24. Graphs showing relations between $A$, delta oxygen-18 and delta nitrogen-15 values with literature values of potential nitrate sources; and $B$, delta nitrogen-15 and nitrate concentrations, from surface-water samples collected from the North Fork Little River Basin, Kentucky .

25. Graph showing sediment-source contributions based on a four-source mixing model in the North Fork Little River, South Fork Little River, and Little River Basins, Kentucky, water years 2013-14. 


\section{Tables}

1. Description of surface-water sampling sites in the North Fork Little River, South Fork Little River, and Little River Basins, Kentucky, water years 2013-14 . .4

2. Partitioning of streamflow at select sites in the South Fork and North Fork Little River Basins using the hydrograph separation program, PART, water years 2013-14 .....7

3. Data used to estimate mean annual loads of total nitrogen and total phosphorus from nonpoint and point sources in the upper Little River Basin, Kentucky, 2013-14 ......9

4. Rainfall on sampling dates for E. coli water and sediment and microbial-source tracking and cumulative rainfall on 1-, 2-, 3-, and 4-day periods before sample dates

5. Fecal reference samples by source, water years 2013-14

6. Summary statistics of $E$. coli for water samples collected at 19 U.S. Geological Survey sites in the Little River Basin, Kentucky, April 2013-September 2013 and May 2014-November 2014

7. Summary statistics of $E$. coli in fluvial sediment samples collected at 19 U.S. Geological Survey sites in the Little River Basin, Kentucky, April 2013September 2013 and May 2014-November 2014

8. Spearman's rank correlation test for median E. coli density in water samples, median E. coli density in fluvial sediment samples, drainage area, and land use.

9. Summary statistics of fecal contamination in environmental water samples collected at 11 U.S. Geological Survey sites in the Little River Basin, Kentucky, April 2013-September 2013 and May 2014-November 2014

10. Analytes for discrete water-quality and suspended sediment samples and analytical methods

11. Predefined regression equations in the LOADEST computer program for estimating loads in rivers and streams.

12. Statistical summary of streamflow, nutrients, and suspended sediment at sampling sites in the upper Little River Basin, 2012-14.

13. Regression coefficients and coefficients for determination $\left(R^{2}\right)$ for load regression equations used to estimate total nitrogen, ammonia plus organic nitrogen, nitrite plus nitrate, total phosphorus, and orthophosphate at select sampling sites in the upper Little River Basin, Kentucky, 2012-14.....

14. Summary of select nutrient loads and yields at select sites in the upper Little River Basin, Kentucky, 2013-14

15. Summary of select nutrient loads and yields, 2003-4 and 2013-14...............................42

16. List of constituents used as tracers to identify sources for sediment fingerprinting .....48

17. Outline of field, laboratory, and statistical techniques used to determine sediment sources

18. Probability that the tracers from the stepwise discriminant function analysis can distinguish between individual source types using the Mahalanobis Distance statistic, Little River Basin, Kentucky, water years 2013-14.

19. Average elemental source concentration plus standard error for the normalized sediment fingerprinting properties included in the mixing model for the four upland-source types

20. Relative source contribution to fine sediment from individual land-cover types using a three-source mixing model based on 1,000 Monte Carlo iterations 


\section{Conversion Factors}

U.S. customary units to International System of Units

\begin{tabular}{lll}
\hline \multicolumn{1}{c}{ Multiply } & By & \multicolumn{1}{c}{ To obtain } \\
\hline inch (in.) & Length & \\
foot (ft) & 2.54 & centimeter $(\mathrm{cm})$ \\
mile (mi) & 0.3048 & meter $(\mathrm{m})$ \\
& 1.609 & kilometer $(\mathrm{km})$ \\
\hline acre & Area & \\
square mile $\left(\mathrm{mi}^{2}\right)$ & 0.004047 & square kilometer $\left(\mathrm{km}^{2}\right)$ \\
\hline & 2.590 & square kilometer $\left(\mathrm{km}^{2}\right)$ \\
\hline gallon (gal) & Volume & \\
\hline & 3.785 & liter $(\mathrm{L})$ \\
\hline cubic foot per second $\left(\mathrm{ft}{ }^{3} / \mathrm{s}\right)$ & Flow rate & \\
million gallons per day $(\mathrm{Mgal} / \mathrm{d})$ & 0.02832 & cubic meter per second $\left(\mathrm{m}^{3} / \mathrm{s}\right)$ \\
\hline & 0.04381 & cubic meter per second $\left(\mathrm{m}^{3} / \mathrm{s}\right)$ \\
\hline ounce & Mass & \\
pound, avoirdupois $(\mathrm{lb})$ & 28.35 & gram $(\mathrm{g})$ \\
ton, short $(2,000 \mathrm{lb})$ & 0.4536 & kilogram $(\mathrm{kg})$ \\
\hline
\end{tabular}

Temperature in degrees Celsius $\left({ }^{\circ} \mathrm{C}\right)$ may be converted to degrees Fahrenheit $\left({ }^{\circ} \mathrm{F}\right)$ as follows:

$$
{ }^{\circ} \mathrm{F}=\left(1.8 \times{ }^{\circ} \mathrm{C}\right)+32 .
$$

Temperature in degrees Fahrenheit $\left({ }^{\circ} \mathrm{F}\right)$ may be converted to degrees Celsius $\left({ }^{\circ} \mathrm{C}\right)$ as follows:

$$
{ }^{\circ} \mathrm{C}=\left({ }^{\circ} \mathrm{F}-32\right) / 1.8 \text {. }
$$

\section{Datum}

Vertical coordinate information is referenced to the North American Vertical Datum of 1988 (NAVD 88).

Horizontal coordinate information is referenced to the North American Datum of 1983 (NAD 83).

\section{Supplemental Information}

Specific conductance is given in microsiemens per centimeter at 25 degrees Celsius $(\mu \mathrm{S} / \mathrm{cm}$ at $\left.25^{\circ} \mathrm{C}\right)$.

Concentrations of chemical constituents in water are given in milligrams per liter $(\mathrm{mg} / \mathrm{L})$ or micrograms per liter ( $\mu \mathrm{g} / \mathrm{L})$.

Concentrations of fecal-indicator bacteria (E. coli) in water are given in most probable number per 100 milliliters (MPN/100 mL). 
Concentrations of fecal-indicator bacteria (E. coli) in fluvial sediment are given in most probable number per gram dry weight sediment (MPN/gram dry weight).

EPA primary contact recreational water concentrations of fecal-indicator bacteria (E. coli) are given in number of colonies per 100 milliliters (col/100 mL).

\section{Abbreviations}

\begin{tabular}{|c|c|}
\hline AMLE & adjusted maximum likelihood estimation \\
\hline BFI & base-flow index \\
\hline $\mathrm{CO}_{2}$ & carbon dioxide \\
\hline$D_{50}$ & median sediment grain size/particle size \\
\hline DCP & data collection platform \\
\hline$\delta^{13} \mathrm{C}$ & delta carbon-13 of sediment total carbon \\
\hline$\delta^{15} \mathrm{~N}_{\mathrm{N} 03}$ & delta nitrogen- 15 of nitrate \\
\hline$\delta^{15} \mathrm{~N}$ & delta nitrogen- 15 of sediment \\
\hline$\delta^{18} 0_{\mathrm{N} 03}$ & delta oxygen-18 of nitrate \\
\hline EPA & U.S. Environmental Protection Agency \\
\hline FIB & fecal-indicator bacteria \\
\hline LOADEST & LOAD ESTimator \\
\hline LRWOC & Little River Water-Quality Consortium \\
\hline MLE & maximum likelihood estimation \\
\hline MPN & most probable number \\
\hline MST & microbial-source tracker \\
\hline $\mathrm{N}_{2}$ & nitrogen gas \\
\hline NFLR & North Fork Little River \\
\hline $\mathrm{NH}_{4+}+\operatorname{orgN}$ & ammonia plus organic nitrogen \\
\hline $\mathrm{NO}_{2}+\mathrm{NO}_{3}$ & nitrite and nitrate \\
\hline NWIS & National Water Information System \\
\hline orthoP & orthophosphorus \\
\hline OWML & Ohio Water Microbiology Laboratory \\
\hline PCR & primary contact recreation \\
\hline per mil & parts per thousand \\
\hline qPCR & quantitative Polymerase Chain Reaction \\
\hline $\mathrm{R}^{2}$ & coefficient of determination \\
\hline ROS & regression on statistics \\
\hline RPD & relative percent difference \\
\hline
\end{tabular}




$\begin{array}{ll}\text { RSIL } & \text { Reston Stable Isotope Laboratory } \\ \text { SFLR } & \text { South Fork Little River } \\ \text { S-LDA } & \text { stepwise linear discriminant analysis } \\ \text { STV } & \text { statistical threshold value } \\ \text { TMDL } & \text { total maximum daily load } \\ \text { TN } & \text { total nitrogen } \\ \text { TP } & \text { total phosphorus } \\ \text { USGS } & \text { U.S. Geological Survey } \\ \text { WWTP } & \text { wastewater-treatment plant }\end{array}$





\title{
Multiple-Source Tracking: Investigating Sources of Pathogens, Nutrients, and Sediment in the Upper Little River Basin, Kentucky, Water Years 2013-14
}

\author{
By Angela S. Crain, Mac A. Cherry, Tanja N. Williamson, and Aubrey R. Bunch
}

\section{Abstract}

The South Fork Little River (SFLR) and the North Fork Little River (NFLR) are two major headwater tributaries that flow into the Little River just south of Hopkinsville, Kentucky. Both tributaries are included in those water bodies in Kentucky and across the Nation that have been reported with declining water quality. Each tributary has been listed by the Kentucky Energy and Environment Cabinet-Kentucky Division of Water in the 303(d) List of Waters for Kentucky Report to Congress as impaired by nutrients, pathogens, and sediment for contact recreation from point and nonpoint sources since 2002. In 2009, the Kentucky Energy and Environment Cabinet-Kentucky Division of Water developed a pathogen total maximum daily load (TMDL) for the Little River Basin including the SFLR and NFLR Basins. Future nutrient and suspended-sediment TMDLs are planned once nutrient criteria and suspended-sediment protocols have been developed for Kentucky. In this study, different approaches were used to identify potential sources of fecal-indicator bacteria (FIB), nitrate, and suspended sediment; to inform the TMDL process; and to aid in the implementation of effective watershed-management activities. The main focus of source identification was in the SFLR Basin.

To begin understanding the potential sources of fecal contamination, samples were collected at 19 sites for densities of FIB (E. coli) in water and fluvial sediment and at 11 sites for Bacteroidales genetic markers (General AllBac, human HF183, ruminant BoBac, canid BacCan, and waterfowl GFD) during the recreational season (May through October) in 2013 and 2014. Results indicated 34 percent of all E. coli water samples ( $n=227$ samples) did not meet the U.S. Environmental Protection Agency 2012 recommended national criteria for primary recreational waters. No criterion currently exists for E. coli in fluvial sediment. By use of the Spearman's rank correlation test, densities of FIB in fluvial sediments were observed to have a statistically significant positive correlation with drainage area. As drainage area increased, so did the densities of FIB in the fluvial sediments. There was no statistically significant correlation between drainage area and FIB in water.
The human-associated marker (HF183) was found above the detection limit in 26 percent of the samples ( $n=120$ samples); a higher proportion of positive samples was in the NFLR Basin. The ruminant-associated marker (BoBac) was above the detection limit in 65 percent of samples; a higher proportion of positive samples was in the headwaters of the SFLR Basin.

Nutrient yields differed between the SFLR and NFLR Basins. Comparatively, the SFLR Basin produced the largest estimated mean yields of total nitrogen $(16,000$ pounds per year per square mile $\left(\mathrm{lb} / \mathrm{yr} / \mathrm{mi}^{2}\right)$ and nitrite plus nitrate nitrogen $\left(12,500 \mathrm{lb} / \mathrm{yr} / \mathrm{mi}^{2}\right)$, and the NFLR Basin produced the largest estimated mean yields of ammonia plus organic nitrogen $\left(4,700 \mathrm{lb} / \mathrm{yr} / \mathrm{mi}^{2}\right)$, total phosphorus $\left(1,100 \mathrm{lb} / \mathrm{yr} / \mathrm{mi}^{2}\right)$, and orthophosphorus $\left(590 \mathrm{lb} / \mathrm{yr} / \mathrm{mi}^{2}\right)$.

Nitrate sources in surface water were assessed in both basins using dual-nitrate isotope (nitrogen and oxygen) ratios. Data from the different land uses in the SFLR Basin showed differences in nitrate concentrations and overlapping, but moderately distinct, isotopic signatures. Predominantly forested sites consistently had low nitrate concentrations (median $=0.233$ milligrams per liter) with minimal variability, and agricultural sites had the highest nitrate concentrations (median $=7.55$ milligrams per liter) with the greatest variability. The median nitrate concentration for sites with mixed land use was 2.66 milligrams per liter. Dual-isotope data for forested sites plotted within ranges characteristic of soil-derived nitrate with possible but minimal influence from recycled atmospheric nitrate. Ranges of dual-isotope data for sites with agricultural and mixed land uses were characteristic of possible mixtures of chemical fertilizer, soil-derived nitrate, and manure and septic wastes. In the NFLR Basin, a positive linear relation was observed between nitrate concentrations and nitrogen isotope ratios $\left(\delta^{15} \mathrm{~N}_{\mathrm{NO} 3}\right)\left(\mathrm{R}^{2}=0.56\right.$; $p$-value $<0.001)$ that potentially suggests the NFLR Basin has a higher proportion of $\delta^{15} \mathrm{~N}_{\mathrm{NO} 3}$-enriched sources, such as manure and sewage. However, mixing of other nitrate-derived sources cannot be excluded, because many values of $\delta^{15} \mathrm{~N}_{\mathrm{NO} 3}$ and concentrations of nitrate showed minimal variation and plotted within dual-nitrate isotope ranges characteristic of fertilizer and soil-derived nitrate sources. 
A sediment-fingerprinting approach was used to quantify the relative contribution of four upland sources in the SFLR Basin (agricultural, pasture, riparian/forest, and streambank) to understand how land management affects suspended-sediment concentration. Carbon isotope ratios $\left(\delta^{13} \mathrm{C}\right)$, together with calcium and carbon concentrations, were the best indicators of sediment source; the uncertainty was less than 11 percent. Fine-sediment samples collected at the SFLR Basin outlet indicated streambanks as the largest source of the fine sediment to the stream followed by cropland and riparian/forestsource areas, respectively; pasture was a minor contributing source. Streambanks and cropland were essentially equal contributors of fine sediment at the NFLR Basin outlet.

\section{Part 1-Introduction}

Many water bodies across the Nation, including several in Kentucky, have reported declining water quality. Nationally, the leading cause of impaired waters is pathogens for about 10,300 reported impaired surface-water bodies, followed by nutrients for about 7,200 surface-water bodies (U.S. Environmental Protection Agency, 2015). Sediment is reported in sixth place for about 6,000 reported impaired surface-water bodies. The high number of reported impaired waters because of pathogens, nutrients, and sediment has resulted in more than 13,500; 7,500; and 4,000 total maximum daily load (TMDL) determinations, respectively, since October 1995 (U.S. Environmental Protection Agency, 2015). A TMDL is a calculation of the total amount of contaminant a water body can assimilate without violating the designated water-quality standard established by the U.S. Environmental Protection Agency (EPA). It assists states in implementing management strategies that are based on water quality and specifically targeted at identified sources to restore and maintain the quality of their water resources (U.S. Environmental Protection Agency, 1999).

Because the South Fork Little River (SFLR) and the North Fork Little River (NFLR) Basins are listed on the 303(d) List of Waters for Kentucky Report to Congress for pathogen, nutrient, and sediment impairments and a pathogen TMDL was developed for the entire Little River Basin, the Little River Water-Quality Consortium (LRWQC) required additional water-quality information to begin preparing a Watershed Plan for implementing effective best-management practices. In cooperation with the LRWQC, the U.S. Geological Survey (USGS) conducted a 3-year study (2 years of data collection) in the SFLR and NFLR Basins to aid in understanding the occurrence and distribution of pathogens, nutrients, and sediment and their potential sources within the headwaters of the Little River Basin; the main focus was in the SFLR Basin (fig. 1). At the request of the LRWQC, the SFLR Basin was studied more extensively because of the higher percentage of cropland in the basin and the increasing number of small dairy operations in the basin. The NFLR Basin was included in the study for comparison to the SFLR
Basin (fig. 1). Information obtained in this study can assist watershed-resource managers in prioritizing effective reduction strategies for sediments and nutrients that can potentially reduce pathogen concentrations in the streams and help guide effective restoration efforts.

In this study, discrete water-quality and suspendedsediment samples were collected monthly in water years 2013-14 at 19 sites unless the streams were dry. During periods of high streamflow, isokinetic, representative samples were collected using the equal-width-increment method (U.S. Geological Survey, variously dated). During base-flow conditions, grab samples were collected at each site.

The study also used several approaches to identify potential sources of nitrate, fecal-indicator bacteria (FIB), and suspended sediment. Kendall (1998), Mayer and Wassenaar (2012), Kendall and others (2007), Burns and others (2009), and Yue and others (2015) have documented the usefulness of dual-nitrate stable isotopes (nitrogen and oxygen) in identifying sources of nitrate and in understanding its transformations in surface waters. These same researchers were successful in tracing contributions of nitrate from one or more sources including fertilizer, atmospheric deposition, and animal and human waste. While the dual-nitrate isotope approach is useful for differentiating most nitrate sources, it is not suitable for differentiating between manure and septic-waste sources; to gain insight into differentiating these specific sources, hostassociated Bacteroidales-based 16S ribosomal ribonucleic acid genetic markers (also referred to as microbial-source tracking (MST) markers) were utilized.

Bacteroidales is an order of bacteria present in high numbers in the gastrointestinal tract of warm-blooded animals with host-specific biomarkers including:

- general fecal marker, AllBac (Layton and others, 2006),

- human fecal marker, HF183 (Seurinck and others, 2005),

- bovine fecal marker, BoBac (Layton and others, 2006),

- canine fecal marker, BacCan (Kildare and others, 2007), and

- waterfowl fecal marker, GFD (Green and others, 2012).

The use of host-specific markers serves to further identify specific bacterial-contaminant sources, particularly in the differentiation of manure and septic waste. Identifying specific bacterial-contaminant sources can be used by the LRWQC to develop and implement a strategy for watershed-management activities.

Successful alleviation of sediment-related issues in a basin requires knowing the sources of sediment. One effective way to track sediment movement within a basin is sediment fingerprinting. Sediment fingerprinting is a well-documented approach to estimating and identifying different land-use sediment contributions through the use of tracers and application of a statistical mixing model (Walling and others, 1993, 1999, 


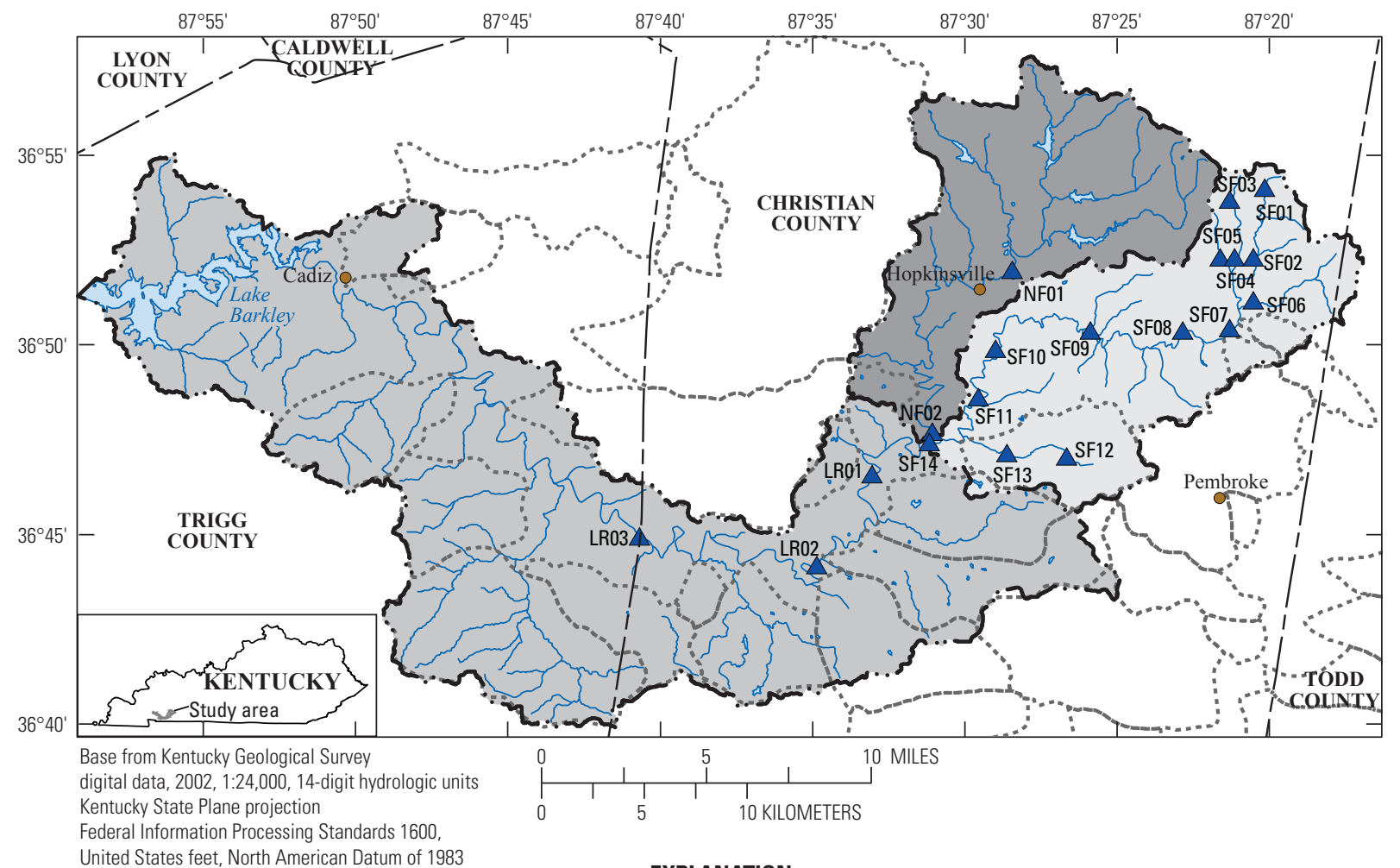

EXPLANATION

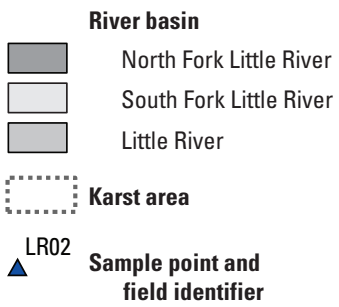

Figure 1. Location of the surface-water sampling sites and karst topography in the North Fork Little River, South Fork Little River, and Little River Basins, Kentucky, water years 2013-14.

2008; Russell and others, 2000). This approach involves characterizing potential upland sediment sources using chemical and physical properties and then comparing those properties to fluvial channel sediment in the stream.

\section{Purpose and Scope}

The purpose of this report is to present streamflow, FIB, nutrient, and suspended-sediment data collected at 19 surfacewater sites during water years 2013-14 (table 1 and fig. 1). A better understanding of the water-quality conditions will inform the TMDL process and aid in the implementation of effective watershed-management activities in the upper Little River Basin.

This report is divided into five parts. Part 1 is the introduction that provides background, a description of the study area, and the approach for this investigation. Parts $2-4$ provide a consolidated resource for the methods, water-quality results, and microbial, nutrient, and sediment source assessments.

Part 5 summarizes the water-quality conditions, and the microbial, nutrient, and sediment source assessments of the study area as detailed in the report.

\section{Description of Study Area}

The environmental settings of the SFLR and NFLR Basins are a complex combination of natural and human factors. Natural factors such as physiography, geology, soils, and hydrology all combine to create a unique setting within both basins. The geology and soils are the primary factors affecting the chemical composition of groundwater and surface waters in the basin. Human factors, such as urban development, farming, and logging also have a substantial effect on water-quality conditions in the basin. 


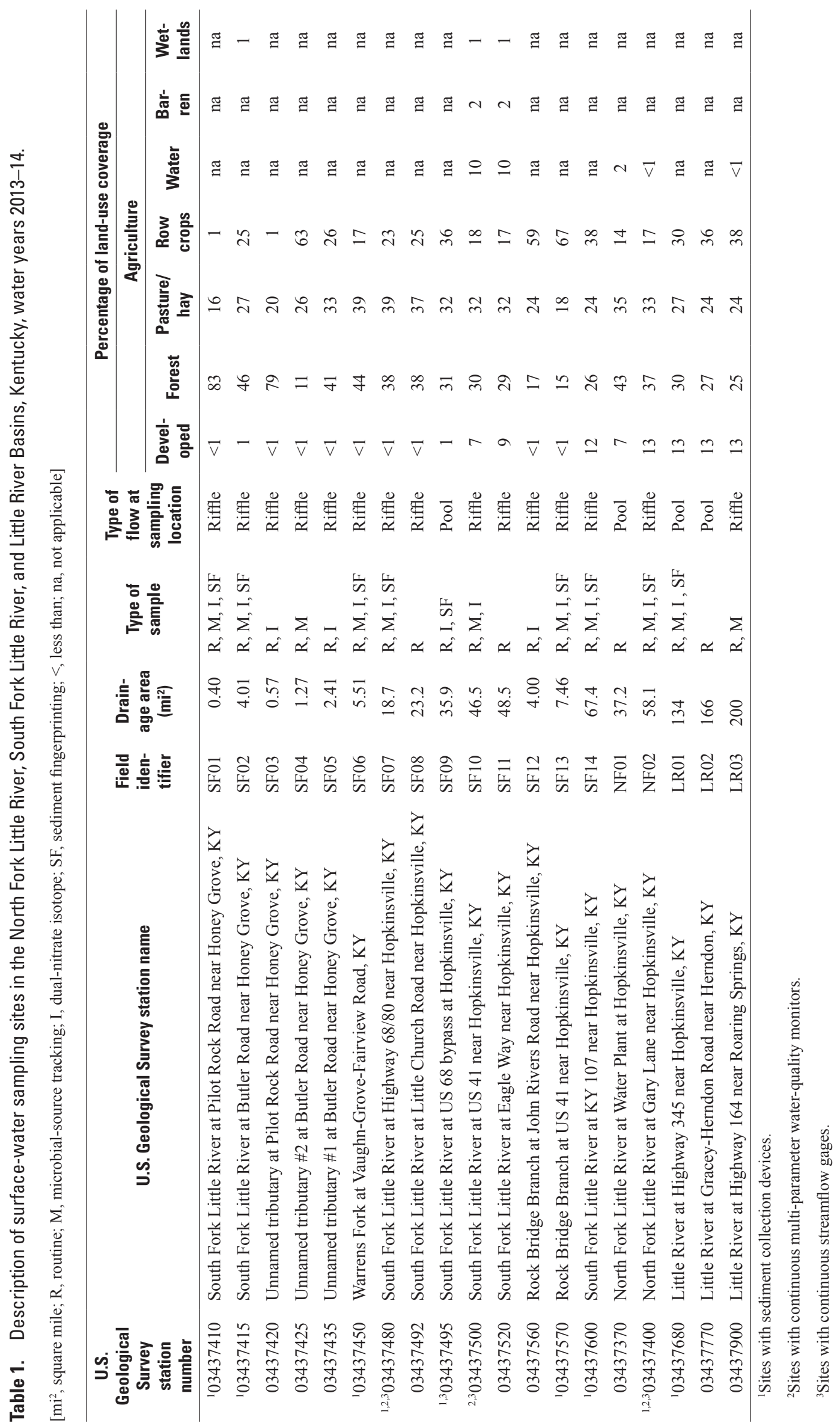




\section{Physiography}

The SFLR Basin $\left(67.4 \mathrm{mi}^{2}\right)$ and the NFLR Basin $\left(58.1 \mathrm{mi}^{2}\right)$ are headwater tributaries in the Little River Basin $\left(601 \mathrm{mi}^{2}\right)$ and lie within the Mississippian Plateau Physiographic Province (also known as the Pennyroyal Region) and are associated with two EPA Level IV Ecological regions within the Pennyroyal Bioregion of Kentucky (fig. 2). The upper half of each basin is associated with the CrawfordMammoth Cave Uplands (Level IV Ecoregion, 71a). The Crawford-Mammoth Cave Uplands ecoregion is composed of hilly uplands containing cliffs and wide karst valleys (Woods and others, 2002). Sinkholes, caverns, springs, and subterranean drainage are common; however, surface drainage can be substantial. The lower half of each basin is associated with the Western Pennyroyal Karst Basin (Level IV Ecoregion, 71e). This ecoregion is composed of mostly upland streams with limited streamflow - many are intermittent or ephemeral that can become laden with suspended sediment after heavy rains.
Sinkholes, caverns, springs, and subterranean drainage are common with well-developed underground drainage.

\section{Geology}

The SFLR and NFLR Basins are underlain primarily by karstic limestone formations of Late Mississippian age (fig. 3). The limestone units of significance within the basin study area are St. Louis and Ste. Genevieve Limestone and formations of Chesterian age (Late Mississippian). The St. Louis Limestone is composed primarily of sequences of massively bedded (tabular) limestones, and the Ste. Genevieve Limestone is composed primarily of thin-bedded, cherty limestones (McDowell, 1986).

Overlying the St. Louis Limestone and Ste. Genevieve Limestone in the upper half of the study area is a thick sequence of limestone, sandstone, and shale formations of Chesterian age that is divided into upper and lower parts. The lower Chesterian is composed of alternating sandstone

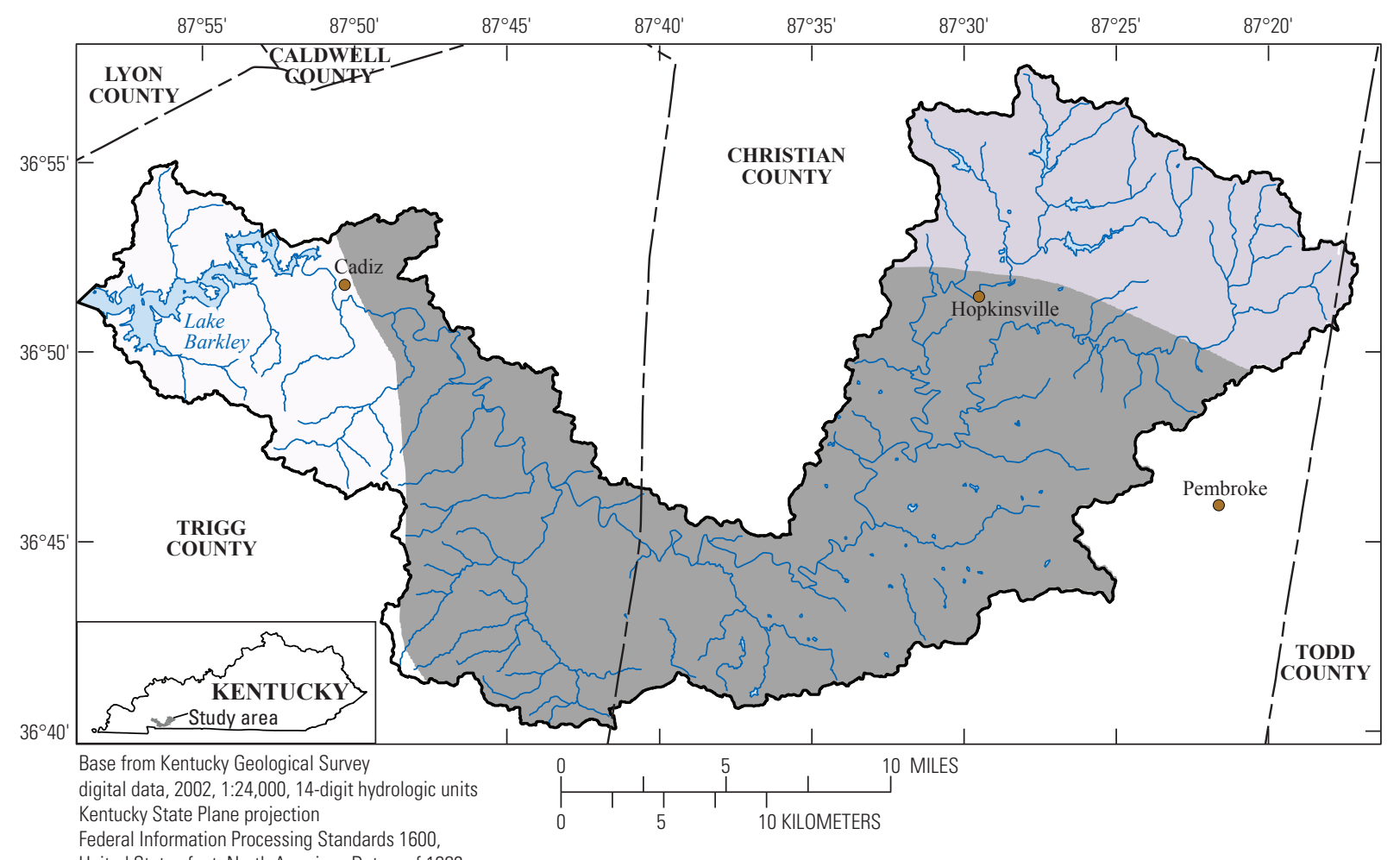

Federal Information Processing Standards 1600,

United States feet, North American Datum of 1983

Figure 2. U.S. Environmental Protection Agency Level IV Ecoregions in the North Fork Little River, South Fork Little River, and Little River Basins, Kentucky. 


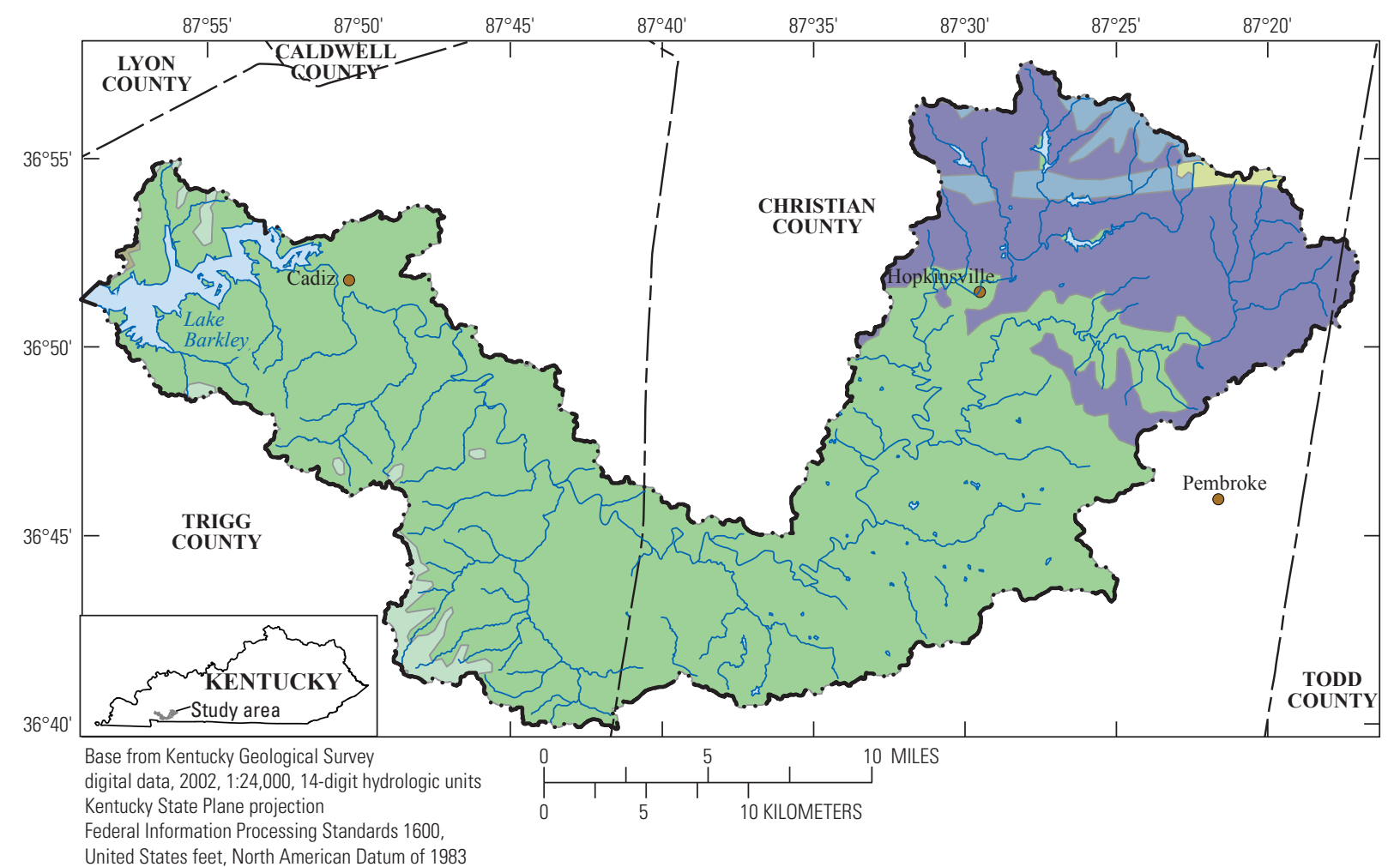

EXPLANATION

Geologic classification

Tusculoosa Formation

Caseyville Formation

Upper Chesterian

Lower Chesterian

St. Genevieve, St. Louis Limestone

Warsaw Formation

Figure 3. Generalized geologic formations in the North Fork Little River, South Fork Little River, and Little River Basins, Kentucky.

and limestone strata that includes the Golconda Formation (sandstone dominated) and the Girkin Limestone (McDowell, 1986). The upper rocks of the Chesterian-age formations are composed mainly of siltstone and shale with alternating minor beds of limestone (McDowell, 1986).

A small area in the far northern portion of the study area is characterized by the Caseyville Formation that is of Pennsylvanian age. The dominant Caseyville Formation lithologies are sandstone, shale, silt shale, and siltstones (in descending order) with several thin coals present (Frazier and Schwimmer, 1987). The sandstone within the Caseyville Formation is notable for containing abundant, well-rounded quartz pebbles (McDowell, 1986).

\section{Hydrology}

Direct surface runoff and groundwater discharge are the major sources of streamflow in the SFLR and NFLR Basins.
Another source is interflow, which is part of the subsurface flow that moves at shallow depths and potentially can reach the surface channels in a short period of time.

Annual mean flow differs appreciably from year to year with variations in weather conditions. The estimated mean annual streamflow of the SF14 site (mouth of stream) was $117 \mathrm{ft}^{3} / \mathrm{s}$ in 2013 and $97.5 \mathrm{ft}^{3} / \mathrm{s}$ in 2014 . The mean annual streamflow of the NF02 site (mouth of stream) was 109 $\mathrm{ft}^{3} / \mathrm{s}$ in 2013 and $98.8 \mathrm{ft}^{3} / \mathrm{s}$ in 2014 . Groundwater discharge, estimated using a base-flow index (BFI) (Rutledge, 1998) in the SFLR and the NFLR was estimated using 2013-14 data from four streamflow gaging stations (sites SF07, SF09, SF10, and SF11) and one site (SF14) at which streamflow was estimated using data from an upstream gaging station. The BFI ranged from 31 to 50 percent of the streamflow in the SFLR Basin during the study period (table 2). The outlet site in the NFLR Basin had a BFI of 49 percent during the study period (table 2). The computed BFIs suggest the hydrology in 
Table 2. Partitioning of streamflow at select sites in the South Fork and North Fork Little River Basins using the hydrograph separation program, PART (Rutledge, 1998), water years 2013-14.

$\left[\mathrm{mi}^{2}\right.$, square mile; $\mathrm{ft}^{3} / \mathrm{s}$, cubic foot per second; in/yr, inch per year; S.F., South Fork; N.F., North Fork]

\begin{tabular}{|c|c|c|c|c|c|c|c|c|}
\hline \multirow{2}{*}{ Basin } & \multirow{2}{*}{ U.S. Geological Survey station name } & \multirow{2}{*}{$\begin{array}{l}\text { Field } \\
\text { identifier }\end{array}$} & \multirow{2}{*}{$\begin{array}{c}\text { Drainage } \\
\text { area } \\
\left(\mathrm{mi}^{2}\right) \\
\end{array}$} & \multicolumn{2}{|c|}{$\begin{array}{c}\text { Mean } \\
\text { streamflow }\end{array}$} & \multicolumn{2}{|c|}{$\begin{array}{c}\text { Mean } \\
\text { base flow }\end{array}$} & \multirow{2}{*}{$\begin{array}{c}\text { Base-flow } \\
\text { index } \\
\text { (percent) }\end{array}$} \\
\hline & & & & $\left(\mathrm{ft}^{3} / \mathrm{s}\right)$ & (in/yr) & $\left(\mathrm{ft}^{3} / \mathbf{s}\right)$ & (in/yr) & \\
\hline \multirow[t]{4}{*}{ South Fork Little River } & $\begin{array}{l}\text { S.F. Little River at Highway } 68 / 80 \\
\text { near Hopkinsville, KY }\end{array}$ & SF07 & 18.7 & 30 & 21.4 & 9.2 & 6.7 & 31 \\
\hline & $\begin{array}{l}\text { S.F. Little River at US } 68 \text { bypass at } \\
\text { Hopkinsville, KY }\end{array}$ & SF09 & 35.9 & 59 & 22.4 & 29 & 11.1 & 50 \\
\hline & $\begin{array}{l}\text { S.F. Little River at US } 41 \text { near } \\
\text { Hopkinsville, KY }\end{array}$ & SF10 & 46.1 & 73 & 21.6 & 35 & 10.4 & 48 \\
\hline & $\begin{array}{l}\text { S.F. Little River at KY } 107 \text { near } \\
\text { Hopkinsville, KY }\end{array}$ & SF14 & 67.4 & 105 & 21.2 & 51 & 10.2 & 48 \\
\hline North Fork Little River & $\begin{array}{l}\text { N.F. Little River at Gary Lane near } \\
\text { Hopkinsville, KY }\end{array}$ & NF02 & 58.1 & 104 & 24.3 & 50 & 11.8 & 49 \\
\hline
\end{tabular}

both basins is likely dominated by surface runoff rather than groundwater discharge, even though the lower portion of the SFLR Basin lies in karst topography (fig. 1). The influence of karst topography on the BFI in the SFLR Basin is not observed, possibly because of only 2 years of streamflow record.

The mean annual precipitation (based on water year) for the Hopkinsville area was 59.5 in. in 2013 and 47.6 in. in 2014 (Western Kentucky University, 2015). The 30-year mean annual precipitation is about $51.1 \mathrm{in}$. for the Hopkinsville area. Average monthly precipitation ranges from about 3 to 5 in. throughout the year.

\section{Land Cover and Land Use}

Land-cover information was derived from the 2005 Kentucky Land Cover Data Set, which includes 15 individual land-cover classes (Kentucky Division of Geographic Information, 2007). Seven principal land-cover categories (developed, forest, pasture, crops, water, barren, and wetlands) were aggregated from the 15 individual land-cover classes. The percentages of land cover in each subbasin are summarized in table 1.

In this report, drainage basins were classified on the basis of major land-use percentages according to the following criteria:

- agricultural: greater than 50 percent agricultural land and less than or equal to 10 percent developed land;

- developed: greater than 20 percent developed land and less than or equal to 30 percent agricultural land;
- forested: greater than 75 percent forested land and less than or equal to 15 percent developed or agricultural land; and

- mixed: all other combinations of developed, agricultural, and forested land.

The SFLR Basin represents about 9 percent of the total land area of Christian County with a small amount of land area in Todd County and is characterized as 36 percent agricultural with predominantly corn, soybean, and wheat production (fig. 4). The NFLR Basin represents 8 percent of the total land area of Christian County and is characterized as 49 percent agricultural with predominantly hay production and pasture, especially in the northern part of the basin. Cultivated crops typically are planted from April to May and harvested in August to October. Agricultural land-management practices include no-till and conventional till in the study area. In 2012, the National Agricultural Statistic Service ranked Christian County as first out of 120 counties in Kentucky in corn production (97,251 acres), soybean production (80,644 acres), and wheat production $(65,917$ acres). Todd County ranked ninth out of 120 Kentucky counties in soybean production (48,590 acres) and third in wheat production (32,722 acres) (U.S. Department of Agriculture, 2012).

Livestock production also is common in the study area. In 2012, Christian County had 88 dairy farms, the highest number of dairy farms in Kentucky counties (U.S. Department of Agriculture, 2013). The high number of dairy farms is, in part, because of a large community of Amish and Mennonite farmers with small dairy herds (less than 50 head). According to the U.S. Department of Agriculture (2013), Todd and Christian Counties ranked fourth and fifth in milk production in Kentucky, respectively. 


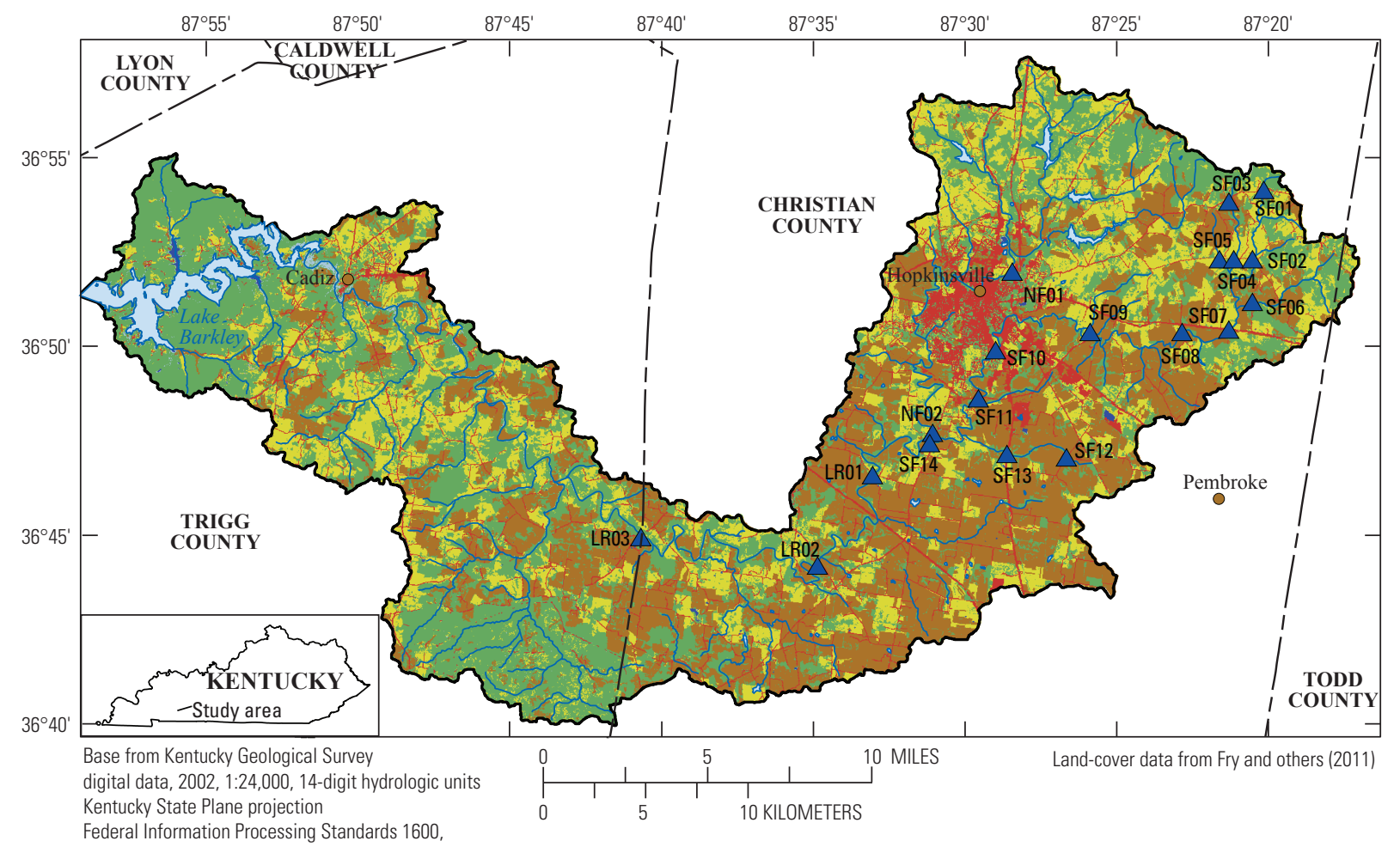

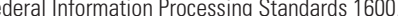

United States feet, North American Datum of 1983

EXPLANATION

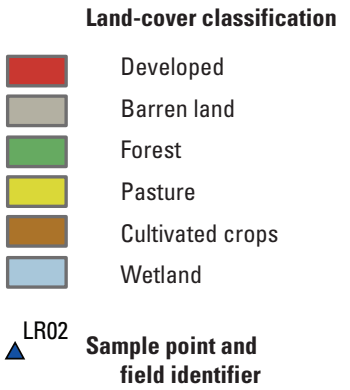

Figure 4. Land use in the South Fork Little River, North Fork Little River, and Little River Basins, Kentucky.

\section{Soils}

The type of soil formed in a particular area is strongly influenced by the climate, parent material, landscape relief, and biological factors. These factors interact dynamically over a period of time (recent events to ancient times) to produce soil profiles that vary with depth and complexity. Soils in most of the study area formed in a mantle of loess underlain by residuum of limestone or in a mantle of loess underlain by residuum of acid sandstone, siltstone, and shale. Soils are described commonly in terms of soil series which is a part of the land area with similar soil properties, such as color, texture, soil horizons, and depth (U.S. Department of Agriculture, 1981).

A detailed county-scale soil survey identifies several major soil series within Christian County (U.S. Department of Agriculture, 1980). The soil series comprising the upper half of the NFLR and SFLR Basins consist primarily of the Sadler, Frondorf, Zanesville, Pembroke, and Caneyville series (U.S. Department of Agriculture, 1980, 1981). The soil series comprising the lower half of the NFLR and SFLR Basins consist primarily of Nicholson, Pembroke and Crider series. In general, all the soil series are moderate deep to deep, ranging from 40 to $100 \mathrm{in}$. to bedrock; moderately well-drained to well-drained ( 0.6 to $2.0 \mathrm{in} / \mathrm{hr}$ ), and loamy or clayey (U.S. Department of Agriculture, 1980). Some soil series in the basin are only moderately well-drained because of the presence of a fragipan (silica cemented soil horizon that reduces vertical water movement). The depth to the fragipan ranges from 15 to $30 \mathrm{in}$. below the surface throughout the basin and can impede water and roots. 


\section{Source Inputs of Nitrogen and Phosphorus}

Sources of nutrients into the upper Little River Basin are categorized as nonpoint or point source. Contaminant sources that are diffuse and do not have a single point of origin into receiving streams are called nonpoint sources. Nonpoint sources of nutrients include atmospheric deposition, fertilizer applications from agricultural and residential areas, feed-lot discharges, septic systems, and urban runoff. Point sources differ from nonpoint sources in that they discharge directly into a receiving stream at a discrete point. Point sources consist primarily of a variety of large and small wastewater-treatment facilities, but nutrient inputs also can come from stormwater runoff and sewer overflows.

Data for estimating inputs of nitrogen and phosphorus from atmospheric deposition (nitrogen only), fertilizer applications, manure applications, nitrogen fixation, and wastewater sources originated from publicly available data and previously published methods (table 3 ). Atmospheric deposition to the study basins was computed using available data from the National Atmospheric Deposition Program (2015) following the methods described in Ruddy and others, 2006. Fertilizer and manure inputs also were computed using methods described in Ruddy and others (2006). The use of county-level data has some limitations in its application because fertilizer and livestock waste sources are not evenly distributed within the counties. The use of county-level data generally is more applicable to large drainage basins that encompass entire counties rather than smaller drainage basins that encompass only parts of one or more counties. The study area encompasses about one-third of Christian County. Therefore, uncertainty exists when using estimates of inputs from farm fertilizer and livestock waste. The amount of nitrogen produced by fixation from soybeans in the study area is based on the area of soybeans planted and an annual nitrogen fixation rate of $105 \mathrm{lb} / \mathrm{acre}$, as used by Hoos and others (1999) from Craig and Kuenzler (1983) for soybeans in the southeast. This rate was multiplied by the amount of harvested soybean acres in Christian County in 2012 (U.S. Department of Agriculture, 2012) to estimate the amount of fixed nitrogen.

Wastewater inputs for nitrogen and phosphorus were obtained from the EPA Discharge Monitoring Report Pollutant Loading Tool (U.S. Environmental Protection Agency, 2012), which calculates loadings from permit and discharge monitoring report data from the EPA Integrated Compliance Information System for the National Pollutant Discharge Elimination System.

\section{Previous Investigations}

The Little River was first listed in the 1998 303(d) List of Impaired Waters for Kentucky Report to Congress. Water resources in the Little River Basin have been studied over the past years by State and Federal agencies. Previous investigations were conducted to determine water quality in streams within the basin and estimate loads delivered to Lake Barkley from the Little River and its tributaries. Crain (2001)

Table 3. Data used to estimate mean annual loads of total nitrogen and total phosphorus from nonpoint and point sources in the upper Little River Basin, Kentucky, 2013-14.

[lb/yr, pound per year; na, not available]

\begin{tabular}{|c|c|c|c|c|c|c|}
\hline \multirow[b]{2}{*}{ Constituent } & \multicolumn{2}{|c|}{ South Fork Little River Basin } & \multicolumn{2}{|c|}{ North Fork Little River Basin } & \multicolumn{2}{|c|}{$\begin{array}{l}\text { Little River Basin (Christian and } \\
\text { Trigg County line) (see fig. 1) }\end{array}$} \\
\hline & $\begin{array}{c}\text { Annual load of } \\
\text { total nitrogen } \\
(\mathrm{Ib} / \mathrm{yr})\end{array}$ & $\begin{array}{c}\text { Annual load of } \\
\text { total phosphorus } \\
(\mathrm{lb} / \mathrm{yr})\end{array}$ & $\begin{array}{c}\text { Annual load of } \\
\text { total nitrogen } \\
(\mathrm{lb} / \mathrm{yr})\end{array}$ & $\begin{array}{c}\text { Annual load of } \\
\text { total phosphorus } \\
\text { (lb/yr) }\end{array}$ & $\begin{array}{c}\text { Annual load of } \\
\text { total nitrogen } \\
\text { (lb/yr) }\end{array}$ & $\begin{array}{c}\text { Annual load of } \\
\text { total phosphorus } \\
\text { (lb/yr) }\end{array}$ \\
\hline & \multicolumn{6}{|c|}{ Inputs to land } \\
\hline Atmospheric deposition $^{1}$ & 209,000 & na & 180,000 & na & 620,000 & na \\
\hline Farm fertilizer $^{2}$ & 950,000 & na & na & 830,000 & na & na \\
\hline Nonfarm fertilizer ${ }^{2}$ & 14,600 & 100 & 12,700 & 90 & 43,300 & 300 \\
\hline Livestock waste $^{3}$ & 850,000 & 330,000 & 740,000 & 290,000 & $2,500,000$ & 990,000 \\
\hline \multirow[t]{2}{*}{ Nitrogen fixation ${ }^{3}$} & 1,100 & na & 930 & na & 3,200 & na \\
\hline & \multicolumn{6}{|c|}{ Inputs to streams } \\
\hline Municipal wastewater discharge ${ }^{4}$ & na & na & ${ }^{5} 24,000$ & 53,000 & na & na \\
\hline \multicolumn{7}{|c|}{${ }^{1}$ Data from National Atmospheric Deposition Program (2015). Nitrogen deposition includes wet-deposition of nitrate and ammonia. } \\
\hline \multicolumn{7}{|c|}{${ }^{2}$ University of Kentucky, Division of Regulatory Services (2012). } \\
\hline \multicolumn{7}{|c|}{${ }^{3}$ U.S. Department of Agriculture (2012). } \\
\hline \multicolumn{7}{|c|}{${ }^{4}$ U.S. Environmental Protection Agency (2012) [Available online at https://cfpub.epa.gov/dmr/compare_dmr_tri_multiyr.cfm]. } \\
\hline${ }^{5}$ Average ammonia load for 2013 an & & & & & & \\
\hline
\end{tabular}


published mean annual loads of nutrients and total suspended solids for water-quality data collected from 1985 through 1997 for a state ambient-monitoring network site in the Little River Basin (Little River at Cadiz, Ky.). Crain (2006) published loads of nutrients and suspended sediments from three tributaries to the Little River and the Little River itself for water years 2003-4. The tributaries included the NFLR, the SFLR, and the Sinking Fork. The SFLR contributed 31 percent of the estimated annual loads of nitrite plus nitrate $\left(\mathrm{NO}_{2}+\mathrm{NO}_{3}\right)$, and 20 percent of the estimated annual loads of total phosphorus (TP) to the Little River. The SFLR also contributed 18 percent of the estimated annual suspended-sediment load to the Little River. The NFLR contributed 18 percent of the estimated annual loads of nitrite plus nitrate $\left(\mathrm{NO}_{2}+\mathrm{NO}_{3}\right)$, and 64 percent of the estimated annual loads of total phosphorus (TP) to the Little River. The NFLR also contributed 36 percent of the estimated annual suspended-sediment load to the Little River.

In addition to the nutrient loading study, the Kentucky Division of Water conducted FIB sampling in May through October (recreation season) from 2000 to 2002 to develop a TMDL for the Little River Basin. Sampling of FIB was again performed in 2009 in the pathogen-impaired segments of the Little River Basin. The established 2009 TMDL for FIB was $1.72 \times 10^{11}$ colonies per day for the SFLR Basin, $3.81 \times 10^{11}$ colonies per day for the NFLR Basin, and $8.26 \times 10^{11}$ colonies per day for the Little River main stem site below the confluence of the SFLR and the NFLR (Kentucky Energy and Environment Cabinet, 2009). This additional effort reported here was to evaluate whether or not the streams with impaired status either met or did not meet the Primary Contact Recreation (PCR) use. PCR use is defined as recreational activities involving substantial risk of ingestion of water, such as swimming during the recreation season of May 1 through October 31, and is based on established criteria levels of fecal coliform or E. coli densities and $\mathrm{pH}$ level.

\section{Study Approach}

An overview of the study design and general methodology is described in the following section. Statistical methods for the estimation and partitioning of streamflow and for the estimation of nutrient loads and yields also are presented. Detailed methodology used in the collection and statistical analyses of FIB, MST markers, dual-nitrate isotope, and sediment fingerprinting sample data are described in their respective sections in the report.

\section{General Study Design}

Data were collected from October 2012 to

November 2014 and are available in Crain and others (2017) at https://doi.org/10.5066/F7ZS2TPW. Initially, there were 17 sites along the SFLR, NFLR, and main stem of the Little River in Christian County, Ky. Shortly after sampling began, two additional sites were added farther downstream on the main stem; site LR02 was added in February 2013 and site LR03 was added in April 2013 (table 1) at the request of the LRWQC. Discrete water-quality, suspended-sediment, stable isotope, FIB, and sediment fingerprinting samples were collected at a combination of some or all of the 19 sites (table 1) following standard USGS methods (U.S. Geological Survey, variously dated). Streamflow gaging stations were colocated at four sampling sites. Discrete water-quality and suspended-sediment samples were collected monthly to determine loads of nutrients and sediment throughout the basin. Stable isotope samples also were collected monthly to help determine sources of nitrogen in the basin. Water temperature, specific conductance, $\mathrm{pH}$, dissolved oxygen, and turbidity were measured during the time of discrete water-quality sample collection. In order to assess quantities and sources of fecal contamination, FIB (E. coli) in water and fluvial sediments, MST, and host-source samples were collected during the recreation season (May to October) (table 1). It should be noted that FIB (fecal coliform) were used in listing streams in the Little River Basin on the 303(d) List of Waters for Kentucky Report to Congress. However, the Kentucky Division of Water allows listings for either FIB (fecal coliform) or FIB (E. coli) for pathogen impairments, because both are indicators for the presence of pathogenic organisms such as Giardia lamblia and Cryptosporidium protozoa, the hepatitis A virus, and so forth, E. coli was selected for this study because it has been shown in ambient waters to be a better predictor of the potential effects to human health (U.S. Environmental Protection Agency, 1986). Fecalreference samples for MST were collected from each potential source group (human, canine, bovine, and waterfowl) to assess marker cross reaction and establish quantitative boundaries for interpreting stream-water results.

Fluvial-target sediment samples were collected at nine select routine sampling sites using a passive sampler that was based on the design described by Phillips and others (2000) to assess sediment sources. Additionally, potential sedimentsources were identified and samples collected from upland source areas and streambanks throughout the SFLR Basin. Detailed sample-method collection for FIB, dual-nitrate isotopes, and sediment fingerprinting is provided in their respective Methods sections.

\section{Selection of Sampling Sites}

Site selection was based on land-use type, areas of known or expected sources, and the confluence of tributaries. Many sampling sites in the study area were at former FIB monitoring sites established by the Kentucky Division of Water for their TMDL program (Kentucky Energy and Environment Cabinet, 2009). This investigative approach focused on understanding bacteria, nutrient, and suspended-sediment concentrations and the natural and human factors that influence them. 


\section{Quality Assurance}

Collection of field blanks and concurrent replicates for nutrient and suspended-sediment samples accounted for about 10 percent of the quality-assurance samples and were included in all discrete sampling activities to estimate contamination bias and variability in the data. Field blanks were used to test for bias caused by sample collection, processing, or analysis. Only one field blank had a detectable level of $\mathrm{NO}_{2}+\mathrm{NO}_{3}$, but the concentration was one to two orders of magnitude below the concentration in the river. Four field blanks in the March 2014 to April 2014 time period had $\mathrm{NH}_{3}+\mathrm{NH}_{4}{ }^{+}$concentrations above the minimum reporting limit of $0.01 \mathrm{mg} / \mathrm{L}$. The contamination may possibly be attributed to the application of anhydrous ammonia to agricultural fields in the vicinity. The elevated $\mathrm{NH}_{3}+\mathrm{NH}_{4}^{+}$levels also contributed to $\mathrm{NH}_{4}^{+}+\operatorname{orgN}$ concentrations being above the minimum reporting limit of $0.07 \mathrm{mg} / \mathrm{L}$ in the same four field blanks. All detectable field blank concentrations were statistically insignificant compared to the environmental sample values; thus, the interpretation of the environmental data was not affected.

Replicate samples were compared by using relative percent differences (RPDs). The RPD of each environmental and replicate sample pair was calculated by the following equation:

$$
R P D=|S 1-S 2| /(S 1+S 2) / 2 * 100,
$$

where

$$
\begin{aligned}
& S 1 \quad \text { is equal to the concentration in the } \\
& \text { environmental sample, in milligrams per } \\
& \text { liter; and }
\end{aligned}
$$

A large RPD can indicate greater variability in those samples. Variability between concurrent replicate pairs for nutrient concentrations, as measured by RPD, ranged from 1 to 20 percent for nutrients; $\mathrm{NH}_{4}^{+}$concentrations had the highest $\mathrm{RPD}$, and $\mathrm{NO}_{2}+\mathrm{NO}_{3}$ concentrations had the lowest $\mathrm{RPD}$. Differences in concentrations, as measured by RPD, within replicate sets for suspended-sediment concentrations were 22 percent. Large differences (greater than 30 percent relative to the mean) have been observed in replicate samples of suspended sediment (Kelly and others, 2001). Kelly and others (2001) attributed the large observed differences in replicate samples of suspended sediment to be the result of temporal variability over the duration of sample collection.

Sixteen replicate samples were analyzed for values of $\delta^{15} \mathrm{~N}_{\mathrm{NO} 3}$ and $\delta^{18} \mathrm{O}_{\mathrm{NO} 3}$ isotopes. The mean RPD for $\delta^{15} \mathrm{~N}_{\mathrm{NO} 3}$ for the 16 pairs was 11 percent, and the mean RPD for $\delta^{18} \mathrm{O}_{\mathrm{NO} 3}$ was 12 percent. The analytical precision for $\delta^{15} \mathrm{~N}_{\mathrm{NO} 3}$ and $\delta^{18} \mathrm{O}_{\mathrm{NO} 3}$ isotopes of nitrate at the USGS Reston Stable Isotope Laboratory is about \pm 0.5 per mil (\%o).
E. coli in water blanks and replicates were used to quantify sample methods, equipment, and laboratory conditions. A total of 15 E. coli blank samples was analyzed during the study period. None of the blanks resulted in quantifiable $E$. coli densities (less than $1 \mathrm{MPN} / 100 \mathrm{~mL}$ ), which verified the laboratory and analytical equipment were sterile and free of contamination. Replicate water samples were collected and analyzed for $E$. coli in the same manner as the environmental samples. In addition to the 225 environmental samples, 43 replicate samples were collected. The RPD range for $E$. coli in water samples was 0 to 81 percent; the mean was 24 percent.

\section{Methods of Streamflow Measurement}

Water elevation (stage) was continuously measured with electronic stage sensors at four sites (table 1). The relation between concurrent stage and streamflow measurements was used to develop a rating curve, which allowed streamflow to be continuously computed (Sauer, 2002). Data were recorded at 15-minute intervals by a Data Collection Platform (DCP) and transmitted via satellite to the USGS National Water Information System (NWIS) database. Streamflow records were computed for each site according to standard USGS procedures (Rantz and others, 1982; Kennedy, 1983). According to methods outlined in Turnipseed and Sauer (2010), manual streamflow measurements were made at 6-week intervals to verify and calibrate the rating at each station. Instantaneous streamflow measurements were also made during monthly routine water-quality sampling.

\section{General Data Analysis}

Water-quality and streamflow data collected for this study were analyzed by use of graphical and statistical techniques. Efforts focused on describing nutrients, dual-nitrate isotopes, FIB, and sediment fingerprinting at select sampling sites and estimating nutrient loads from three selected sites (NF02, SF09, and SF14).

The statistical variability in the water-quality data is depicted by boxplots that serve as graphical summaries that are based on percentiles of the data distribution (Helsel and Hirsch, 2002). Boxplots are used to statistically categorize data, visually indicate the variation and skewness of the data, and identify outliers. Median values were used for comparison because they lessen the effects of outliers on the data (Helsel and Hirsch, 2002). For example, the median (50th percentile) represents the "middle" concentration- 50 percent of the data are above that concentration and 50 percent of the data are below that concentration. Detailed statistical analysis methods used in FIB, MST markers, dual-nitrate isotope, and sediment fingerprinting sample data are described in their respective sections in the report. 


\section{Part 2-Microbiological Water-Quality and Source Assessment}

\author{
Lead Author: Mac Cherry
}

Threats to human health and the extent of microbiological impairments of streams direct the need to monitor for fecal contamination using FIB such as fecal coliform, E. coli, or enterococci. These waterborne pathogens are associated with fecal material from humans and other warm-blooded animals. The elevated presence of FIB in surface waters can pose a health risk to humans exposed through recreational activities (for example, swimming, boating, and fishing) in surface waters.

Monitoring of FIB in streams is a valuable tool for helping water-resource managers identify effective watershedmanagement activities that will effectively reduce fecal contamination. However, implementation plans for watershedmanagement activities in impaired streams commonly require the identity of the source of the fecal contamination. One approach to determining the sources of fecal contamination is through MST methods. MST methods are based on the concept that fecal material from different warm-blooded hosts have unique FIB characteristics that enable their identification in water. A widely used MST method is the use of host-associated Bacteroidales genetic markers. Data collection and analysis of FIB and MST are discussed in the following sections.

\section{Collection and Laboratory Analysis of E. coli Samples}

Fecal-indicator bacteria indicates the potential presence of waterborne pathogens that originate from the intestinal tracts of warm-bloodied animals. Those waterborne pathogens, including bacteria, viruses, protozoa, and various parasites, can range from those causing common diarrhea to hepatitis. The direct detection and enumeration of pathogens is difficult, expensive, and frequently unfeasible; therefore, FIB, such as E. coli, are sampled as a proxy for general fecal contamination (U.S. Environmental Protection Agency, 2003). From April to October 2013 and May to November 2014, water and fluvial sediment $E$. coli samples were collected at all sites, and MST water samples were collected at eleven sites (table 1). Hostsource samples were collected from a wastewater treatment plant (WWTP), urban parks, and active pasture fields. Because of the large number of sites and short holding times of $E$. coli water samples, $E$. coli and MST samples were collected at different times than the nutrient and isotope samples. Samples were collected across a range of meteorological conditions (table 4). If a stream at a sampling point was not flowing, no sample was collected.

\section{Water Column}

A total of 227 water samples were collected by the USGS across a range of climactic conditions at 19 sites and analyzed for $E$. coli densities (table 1). All E. coli water samples were collected following USGS approved methods (U.S. Geological Survey, variously dated). Samples were collected with sterile Whirl-Paks ${ }^{\circledR}$ using the hand-dip method (U.S. Geological Survey, variously dated). In most instances, samples were collected from a riffle, but if the site did not have a riffle for a reasonable reach, a grab sample was collected from a pool (table 1). After collection, the samples were chilled and transported to the USGS Indiana-Kentucky Water Science Center Murray Field Office in Murray, Ky., for analysis. The time between sample collection and the start of incubation was less than 8 hours for all samples. Water samples were analyzed for $E$. coli densities using the Colilert ${ }^{\circledR} /$ Quanti-Tray ${ }^{\circledR} 2000$ method (IDEXX Laboratories, 2009). The EPA approved the Colilert $^{\circledR}$ method for quantification of fecal contamination (U.S. Environmental Protection Agency, 2003). Laboratory preparation, dilution ratios, well counts, and quality assurance/ quality control followed the guidelines established in Myers and others (2007). Densities were calculated with the IDEXX Most Probable Number (MPN) generator version 3.2 (https://www.idexx.com/water/mpn-generator.html).

\section{Fluvial Sediments}

A total of 238 FIB fluvial sediment samples were collected by the USGS at the 19 sites (table 1) and analyzed for E. coli densities. At each site, two to three replicate samples were collected with sterile fluorinated plastic jars that were submersed below the water surface, opened, and then used to scoop fluvial sediments (U.S. Geological Survey, variously dated). After collection, the samples were iced and shipped overnight to the USGS Ohio Water Microbiology Laboratory (OWML) for analysis.

At the OWML, fluvial sediment samples were analyzed for $E$. coli densities within 24 hours of arrival. Additional processing steps, as described in Francy and Darner (1998), were required before analyzing by the Colilert Quanti-Tray $/ 2000^{\circledR}$ method (IDEXX Laboratories, 2009). Each replicate sample had $55 \mathrm{~g}$ of sediment aseptically removed and composited in a sterile 1-L jar (Myers and others, 2007). The material in the composited container was mixed and placed in a sterile bottle containing $200 \mathrm{~mL}$ of phosphate buffer. Percent dry weight was determined by taking a second aliquot of sediment from the composited container and drying the material for 24 hours at $105^{\circ} \mathrm{C}$. The sample was placed on a wrist-action shaker for 45 minutes, suspended materials were allowed to settle for 30 seconds, and the liquid phase was decanted for Colilert analysis. Francy and Darner (1998) describes how to convert MPN to MPN per gram of dry weight sediment. 
Table 4. Rainfall on sampling dates for E. coli water and sediment and microbial-source tracking and cumulative rainfall on 1-, 2-, 3-, and 4-day periods before sample dates.

[in., inch]

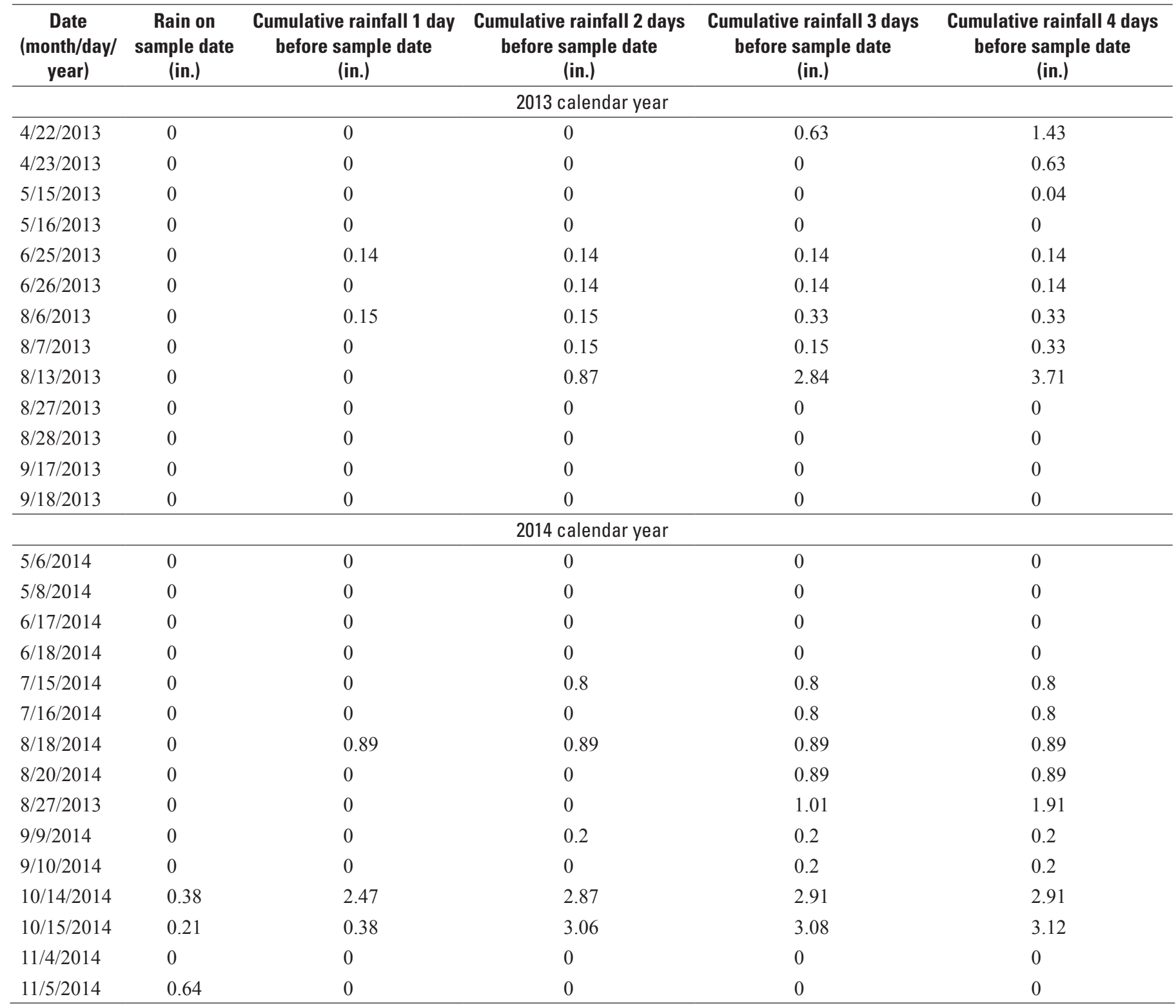

\section{Statistical Analysis of $E$. coli Samples}

The R environment, a suite of software packages based on the "S" programming language, was used for statistical computations (R Development Core Team, 2014). The USGSwsQW package (ver. 0.6.4) was used to compute $E$. coli water and $E$. coli fluvial sediment summary statistics (Lorenz, 2015).

\section{Water Column}

Many E. coli water density values were left-censored. Mean values were computed using the maximum likelihood estimation (MLE) method and other summary statistics were computed using a robust semiparametric method known as regression on order statistics (ROS) (Helsel and Cohn, 1988; Helsel, 2012).

Statistical relations between E. coli water samples and site location were defined using the nonparametric Peto and Peto modification of the Gehan-Wilcoxon test followed by a nonparametric multiple comparison test if statistically significant differences were determined (Helsel, 2012; Harrington and Fleming, 1982). A Spearman's rank correlation test was used to examine the influence of drainage area on E. coli water data. Drainage area and E. coli water data were $\log _{10}$ transformed prior to statistical analysis. Spearman's rho was 
computed on the ranks of the data. Rho values vary between -1 and +1 ; values closer to -1 indicate an inverse correlation, and values closer to +1 indicate a positive correlation. Rho values close to zero indicate no correlation (Helsel and Hirsch, 2002). A significance level (alpha value) of 0.05 was used for all statistical tests. The significance level is the probability ( $p$-value) of incorrectly rejecting the null hypothesis.

\section{Fluvial Sediments}

Mean values were computed using the MLE method and the quantiles from the Kaplan-Meier method "flipped K-M" on flipped data described by Helsel (2012). Statistical relations between $E$. coli fluvial sediment samples and site location were defined using the same statistical methodology as the E. coli water samples.

\section{Collection and Laboratory Analysis of Bacteroidales Genetic Markers}

Fecal-indicator bacteria can provide insight on general fecal contamination, but they do not identify the contamination source. MST methods have been developed to identify host-specific sources of fecal contamination. During the study period, 146 water and host-source samples were collected and analyzed for MST host-source markers including mixed source, human, bovine (domestic cattle), canine, and waterfowl. MST samples were collected whenever E. coli water and fluvial sediment samples were collected (table 1). Samples were immediately chilled and shipped overnight to the OWML.

Water samples were filtered at the OWML the day after collection. The volume of sample filtered ranged from 50 to $100 \mathrm{~mL}$ depending on the clarity of the sample. Filters were placed in a vial containing $0.3 \mathrm{~g}$ of acid-washed beads, and the vials were stored at $-70{ }^{\circ} \mathrm{C}$ until subsequent DNA extraction and analysis by the quantitative polymerase chain reaction (qPCR) method. DNA was extracted from the filters with the GeneRite DNA-EZ ${ }^{\mathrm{TM}}$ extraction kit according to manufacturer instructions.

MST samples were analyzed for five host-associated Bacteroidales and Helicobacter markers by qPCR. Bacteroidales and Helicobacter are groups of enteric bacteria found in the feces of different warm-blooded animal. Because Bacteroidales can be host specific to different warm-blooded animal, they are used to identify target hosts when more than one warm-blooded animal contributes fecal contamination. The five fecal contamination markers are GenBac, general fecal contamination Bacteroidales marker (Dick and Field, 2004; U.S. Environmental Protection Agency, 2010); Bacteroidales HF183, human-associated Bacteroidales marker (Seurinck and others, 2005); BoBac, ruminant-associated Bacteroidales marker (Layton and others, 2006); GFD, waterfowl-associated Helicobacter marker (Green and others, 2012); and BacCan, canine-associated Bacteroidales marker (Kildare and others, 2007).

\section{Statistical Analysis of Bacteroidales Genetic Markers}

A majority of genetic markers had a large number of left-censored data, thus limiting the statistical analysis. If the data met the assumptions of the statistical methods, the mean was computed with the MLE method and the quantiles from the Kaplan-Meier method "flipped K-M" on flipped data described by Helsel (2012). In the case of the GenBac marker, the Kruskal-Wallis test (Kruskal and Wallis, 1952) was used because none of the data were censored. All statistical tests were evaluated at the 95-percent confidence level $(\alpha=0.05)$.

\section{Results of Microbiological Water Quality}

Samples of water and fluvial sediment were collected and analyzed for E. coli between April to October 2013 and May to November 2014 at 19 sites. During the same period, MST and host-source reference samples were collected to help identify sources of fecal contamination (table 5).

\section{E. coli in Water and Fluvial Sediments}

Kentucky recreational water-quality FIB criteria are based on multiple samples collected within 30 days. Because samples for this study were collected monthly, these data are not adequate for comparison to Kentucky recreational waterquality criteria. Instead, a statistical threshold value (STV) issued by the EPA was used. An STV is based on a percentage of samples exceeding a statistical percentile, and if that percentile is exceeded, the water body does not meet the EPA standard for primary contact recreation waters.

Median E. coli water densities ranged from 74 to $745 \mathrm{MPN} / 100 \mathrm{~mL}$, and maximum densities ranged from 1,200 to $66,000 \mathrm{MPN} / 100 \mathrm{~mL}$ (table 6 , fig. 5). On the basis of the STV recommended by the EPA for primary contact recreational waters, 10 percent of the $E$. coli water samples should not exceed $410 \mathrm{col} / 100 \mathrm{~mL}$ (U.S. Environmental Protection Agency, 2012). Thirty-four percent of all water samples exceeded the EPA criteria for primary contact recreational waters.

Statistically significant differences of $E$. coli in water densities among the sites were observed $(p$-value $<0.001$ ) (fig. 6). Most sites in close proximity were not statistically different, indicating only small fluctuations in fecal contamination in short river spans, but the exceptions are sites NF01 to NF02, SF01 to SF02, and SF07 to SF08.

Statistical comparisons of median of E. coli water densities at two NFLR main-stem sites (NF01 and NF02) indicated significant differences $(p$-value $=0.038$ ). Site NF01 had the lowest median E. coli water density, and site NF02 had the highest median E. coli water density. Although site NF02 is downstream from a WWTP, the WWTP had a good compliance record and met its Kentucky Pollutant Discharge Elimination System permit requirements (monthly and weekly 
Table 5. Fecal reference samples by source, water years 2013-14.

[copies/100 mL, copies per 100 milliliter; WWTP, wastewater treatment plant; copies/gDW, copies per gram dry weight; <, less than]

\begin{tabular}{|c|c|c|c|c|c|c|}
\hline Date & Source & $\begin{array}{c}\text { Genbac }^{1} \\
\text { (copies/100 mL) }\end{array}$ & $\begin{array}{c}\text { HF18322 }^{2} \\
\text { (copies/100 mL) }\end{array}$ & $\begin{array}{c}\text { BacCan }^{3} \\
\text { (copies/100 mL) }\end{array}$ & $\begin{array}{l}\text { BoBac }^{4} \text { median } \\
\text { (copies/100 mL) }\end{array}$ & $\begin{array}{c}\text { GFD }^{5} \text { mean } \\
\text { (copies/100 mL) }\end{array}$ \\
\hline $9 / 16 / 2013$ & WWTP1 & $1,634,143,283$ & $12,319,887$ & 353,676 & $3,255,882$ & $<5,400$ \\
\hline $9 / 16 / 2013$ & WWTP2 & $1,731,406,240$ & $8,498,650$ & 276,841 & $1,676,610$ & $<5,400$ \\
\hline $9 / 16 / 2013$ & WWTP3 & $1,580,775,087$ & $9,364,300$ & 310,808 & $1,604,591$ & $<5,400$ \\
\hline $9 / 16 / 2013$ & WWTP4 & $1,581,491,631$ & $8,186,671$ & 306,335 & $2,041,147$ & $<5,400$ \\
\hline $9 / 16 / 2013$ & WWTP5 & $1,492,373,700$ & $9,641,265$ & 297,571 & $1,496,566$ & $<5,400$ \\
\hline Date & Source & $\begin{array}{c}\text { Genbac }^{1} \\
\text { (copies/gDW) }\end{array}$ & $\begin{array}{c}\text { HF183² }^{2} \\
\text { (copies/gDW) }\end{array}$ & $\begin{array}{c}\text { BacCan }^{3} \\
\text { (copies/gDW) }\end{array}$ & $\begin{array}{l}\text { BoBac }^{4} \text { median } \\
\text { (copies/gDW) }\end{array}$ & $\begin{array}{c}\text { GFD }{ }^{5} \text { mean } \\
\text { (copies/gDW) }\end{array}$ \\
\hline $6 / 5 / 2013$ & $\operatorname{Dog} A$ & $3,839,053,230$ & $<500$ & $1,910,437,052$ & $<420$ & $<540$ \\
\hline $6 / 5 / 2013$ & Dog B & $25,750,951$ & $<500$ & 885 & $6,605,036$ & $<540$ \\
\hline $6 / 5 / 2013$ & $\operatorname{Dog} C$ & $1,584,755,643$ & 55,496 & $<780$ & $69,092,336$ & $<540$ \\
\hline $6 / 5 / 2013$ & Dog D & $<760$ & $<500$ & $<780$ & $<420$ & $<540$ \\
\hline $3 / 6 / 2014$ & Cow A & $771,947,591,207$ & 178,482 & $13,935,506$ & $292,050,783,412$ & $<82,471$ \\
\hline $3 / 6 / 2014$ & Cow B & $399,517,193,731$ & 263,686 & $1,170,985$ & $23,982,377,083$ & $<35,218$ \\
\hline $3 / 6 / 2014$ & Cow C & $167,488,751,744$ & $1,151,651$ & $2,567,311$ & $345,727,887,665$ & $<37,437$ \\
\hline $3 / 6 / 2014$ & Cow D & $180,051,000,169$ & $<455$ & $2,237,687$ & $221,137,830,136$ & $<57,756$ \\
\hline $3 / 6 / 2014$ & Cow E & $371,024,071,892$ & $3,765,019$ & $7,631,749$ & $40,425,446,175$ & $<7,172$ \\
\hline $3 / 6 / 2014$ & Cow F & $158,271,872,955$ & $<355$ & $3,682,220$ & $43,418,822$ & $<802,781$ \\
\hline $3 / 6 / 2014$ & Cow G & $492,986,993,973$ & $<477$ & $4,231,468$ & $118,611,726$ & $<38,028$ \\
\hline $3 / 6 / 2014$ & Cow $\mathrm{H}$ & $365,644,502,033$ & $<511$ & $7,072,071$ & $10,437,203$ & $<104,477$ \\
\hline $3 / 6 / 2014$ & Cow I & $254,004,345,197$ & $<473$ & $6,350,160$ & $379,166,508,029$ & $<4,275$ \\
\hline $3 / 6 / 2014$ & Cow J & $385,784,098,038$ & $1,229,409$ & $6,870,012$ & $43,146,587,127$ & $<48$ \\
\hline $3 / 6 / 2014$ & Chicken A & $327,427,808$ & 52,284 & 287,374 & $7,016,347,490$ & $<80,218$ \\
\hline $3 / 6 / 2014$ & Chicken B & $97,358,841$ & $<82$ & 401,887 & $16,343,100,510$ & $<301,924$ \\
\hline $3 / 6 / 2014$ & Chicken C & $940,691,178$ & 282,716 & $2,314,055$ & $19,457,994,861$ & $<1,505,420$ \\
\hline $3 / 6 / 2014$ & Chicken D & $532,279,698$ & $<138$ & 110,955 & 509,180 & $<1,407,926$ \\
\hline $3 / 6 / 2014$ & Chicken E & $336,762,187$ & 85,525 & 68,724 & $3,267,104$ & $<612,907$ \\
\hline $3 / 6 / 2014$ & Chicken F & $235,835,464$ & 80,667 & 56,737 & 899,016 & $<91,446$ \\
\hline
\end{tabular}

${ }^{1}$ Genbac, Bacteriodales marker for general fecal contamination (Dick and Field, 2004; EPA, 2010).

${ }^{2} \mathrm{HF} 183$, Bacteriodales marker for human-associated fecal contamination (Seurinck and others, 2005).

${ }^{3}$ BacCan, Bacteriodales marker for canine-associated fecal contamination (Kildare and others, 2007).

${ }^{4}$ BoBac, Bacteriodales marker for ruminat-associated fecal contamination (Layton and others, 2006).

${ }^{5} \mathrm{GFD}$, Bacteriodales marker for water fowl-associated fecal contamination (Green and others, 2012).

averages $<200$ and $<400 \mathrm{col} / 100 \mathrm{~mL}$ of fecal coliform density, respectively) during 2013 and 2014 (period of study). The WWTP has noted, however, that heavy rainfall events can cause a sanitary sewer overflow at the facility (J.R. Wauford and Company Consulting Engineers, Inc., and JV Engineering, Inc., 2015). The difference in $E$. coli water densities between sites NF01 and NF02 was greater than any other sampling site comparisons. The difference in E. coli water densities may result from unknown contributing sources from the several tributaries that enter the NFLR mainstem between the sites. However, the tributaries and the stream reach between sites NF01 and NF02 were not sampled.
Statistical comparisons of median E. coli water densities showed two SFLR headwater main-stem sites (SF01 and SF02) were significantly different. Site SF01 had the lowest median E. coli water density, and site SF02 had one of the highest median E. coli water densities in the SFLR. Although less than 2 river miles separate sites SF01 and SF02, the land use at the sites differs substantially. Site SF01 is in a highly forested area ( 83 percent) of the basin with few domesticated animals (pets or livestock), and site SF02 is in a highly agricultural area (52 percent). Sites SF07 and SF08 are located mid-basin, are relatively close, slightly over 1 river mile apart, and have similar land uses (fig. 1; table 1). Site SF07 had a 
Table 6. Summary statistics of E. coli for water samples collected at 19 U.S. Geological Survey sites in the Little River Basin, Kentucky, April 2013-September 2013 and May 2014-November 2014.

[Concentrations in most probable number per 100 milliliters; Station ID, U.S. Geological Survey site identification number; ND, no data]

\begin{tabular}{|c|c|c|c|c|c|c|c|c|c|}
\hline Station ID & $\begin{array}{c}\text { Field } \\
\text { identifier }\end{array}$ & $\begin{array}{l}\text { Number of samples } \\
\text { (censored) }\end{array}$ & Minimum & $\begin{array}{c}\text { 25th } \\
\text { percentile }\end{array}$ & Median & Mean & $\begin{array}{c}\text { 75th } \\
\text { percentile }\end{array}$ & Maximum & $\begin{array}{c}\text { Geometric } \\
\text { mean }\end{array}$ \\
\hline \multicolumn{10}{|c|}{ Most probable number per 100 milliliters } \\
\hline${ }^{1} 03437370$ & NF01 & $11(0)$ & 10 & 52 & 74 & 987 & 140 & 10,000 & 46 \\
\hline${ }^{2} 03437400$ & NF02 & $12(0)$ & 10 & 240 & 745 & 1,737 & 2,800 & 5,900 & 1,252 \\
\hline${ }^{1} 03437410$ & SF01 & $13(0)$ & 10 & 31 & 110 & 246 & 300 & 1,200 & 110 \\
\hline${ }^{2} 03437415$ & SF02 & $11(0)$ & 110 & 170 & 530 & 2,715 & 1,400 & 23,000 & 424 \\
\hline 1,203437420 & SF03 & $13(0)$ & 74 & 150 & 320 & 1,111 & 630 & 6,600 & 359 \\
\hline 1,203437425 & SF04 & $7(0)$ & 20 & 130 & 670 & 2,793 & 5,200 & 12,000 & 367 \\
\hline 1,203437435 & SF05 & $9(1)$ & 27 & 170 & 200 & 1,080 & 370 & 6,500 & $\mathrm{ND}$ \\
\hline 1,203437450 & SF06 & $12(0)$ & 41 & 200 & 280 & 1,118 & 480 & 9,600 & 351 \\
\hline 1,203437480 & SF07 & $11(0)$ & 31 & 230 & 670 & 2,493 & 1,500 & 19,000 & 586 \\
\hline${ }^{1} 03437492$ & SF08 & $15(0)$ & 20 & 63 & 200 & 1,330 & 410 & 16,000 & 202 \\
\hline 1,203437495 & SF09 & $14(0)$ & 41 & 190 & 265 & 1,242 & 550 & 11,000 & 297 \\
\hline${ }^{2} 03437500$ & SF10 & $13(0)$ & 110 & 190 & 300 & 1,353 & 400 & 12,000 & 265 \\
\hline 1,203437520 & SF11 & $12(1)$ & 50.1 & 104 & 185 & 1,188 & 345 & 12,000 & ND \\
\hline 1,203437560 & SF12 & $13(0)$ & 52 & 170 & 210 & 2,707 & 560 & 17,000 & 260 \\
\hline${ }^{1,2} 03437570$ & SF13 & $13(0)$ & 30 & 280 & 390 & 591 & 930 & 1,300 & 461 \\
\hline${ }^{2} 03437600$ & SF14 & $11(0)$ & 130 & 230 & 310 & 5,125 & 2,000 & 49,000 & 448 \\
\hline 1,203437680 & LR01 & $12(0)$ & 41 & 205 & 295 & 889 & 700 & 66,000 & 264 \\
\hline${ }^{1,2} 03437770$ & LR02 & $13(0)$ & 98 & 160 & 270 & 890 & 300 & 8,200 & 235 \\
\hline${ }^{2} 03437900$ & LR03 & $12(0)$ & 160 & 220 & 300 & 1,348 & 390 & 13,000 & 291 \\
\hline
\end{tabular}

${ }^{1,2}$ Station IDs with different numbers are significantly different at the 95 -percent confidence level.

median E. coli water density nearly three times greater than site SF08, and their median values were statistically different (table 6). The differences in E. coli water densities between sites SF07 and SF08 may be attributed to a source directly upstream from site SF07 resulting in higher E. coli water densities at this site.

Because E. coli can survive in fluvial sediments and bank soils (Cinotto, 2005; Pachepsky and Shelton, 2011), creating the potential for resuspension into the water column (Wilkinson and others, 2006; Pachepsky and others, 2009), fluvial sediment samples were collected and analyzed for E. coli at all sites. Summary statistics of $E$. coli in fluvial sediments are presented in table 7. The median E. coli densities ranged from 61 to $960 \mathrm{MPN} /$ gram dry weight of sediment, and maximum E. coli densities ranged from 380 to $320,000 \mathrm{MPN} /$ gram dry weight of sediment.

Sites NF01 and NF02 in the NFLR Basin had median E. coli densities of 610 and $240 \mathrm{MPN} / \mathrm{gram}$ dry weight of sediment, respectively (table 7). This relation is opposite of the median E. coli water sample densities where site NF02 was ten times greater than site NF01 (table 6). Site NF01 had the highest enumerated $E$. coli density of 320,000 MPN/gram dry weight of sediment. Site NF01 is located in a large pool (table 1). The pool has lower stream velocities and a greater area for deposition than the other sampling sites and could be a factor in the higher $E$. coli fluvial sediment densities.

The SF01 site had the lowest median density of E. coli in fluvial sediments (table 7). Additionally, site SF01 had relatively low E. coli densities in water, statistically smaller than five other sites (fig. 6). Site SF01 is a headwater site with a small drainage area $\left(0.4 \mathrm{mi}^{2}\right)$ and a high percentage of forest (83 percent) (table 1). These two factors in combination likely result in lower E. coli water and fluvial sediment densities.

The highest $E$. coli fluvial sediment median from the entire study area was from the SFLR at site SF09 (table 7, fig. 7). Site SF09 has a low channel slope, no visible riffle, and low stream velocities, which creates a large deposition zone for sediment. The low velocity in this pool, similar to site NF01, could favor E. coli settling out of the water column into the fluvial sediment.

Spearman's rho was computed to evaluate correlation of drainage area and percentage land use with $E$. coli densities. $\log _{(10)}$ transformed $E$. coli water and fluvial sediment density medians were evaluated with $\log _{(10)}$ transformed drainage areas 


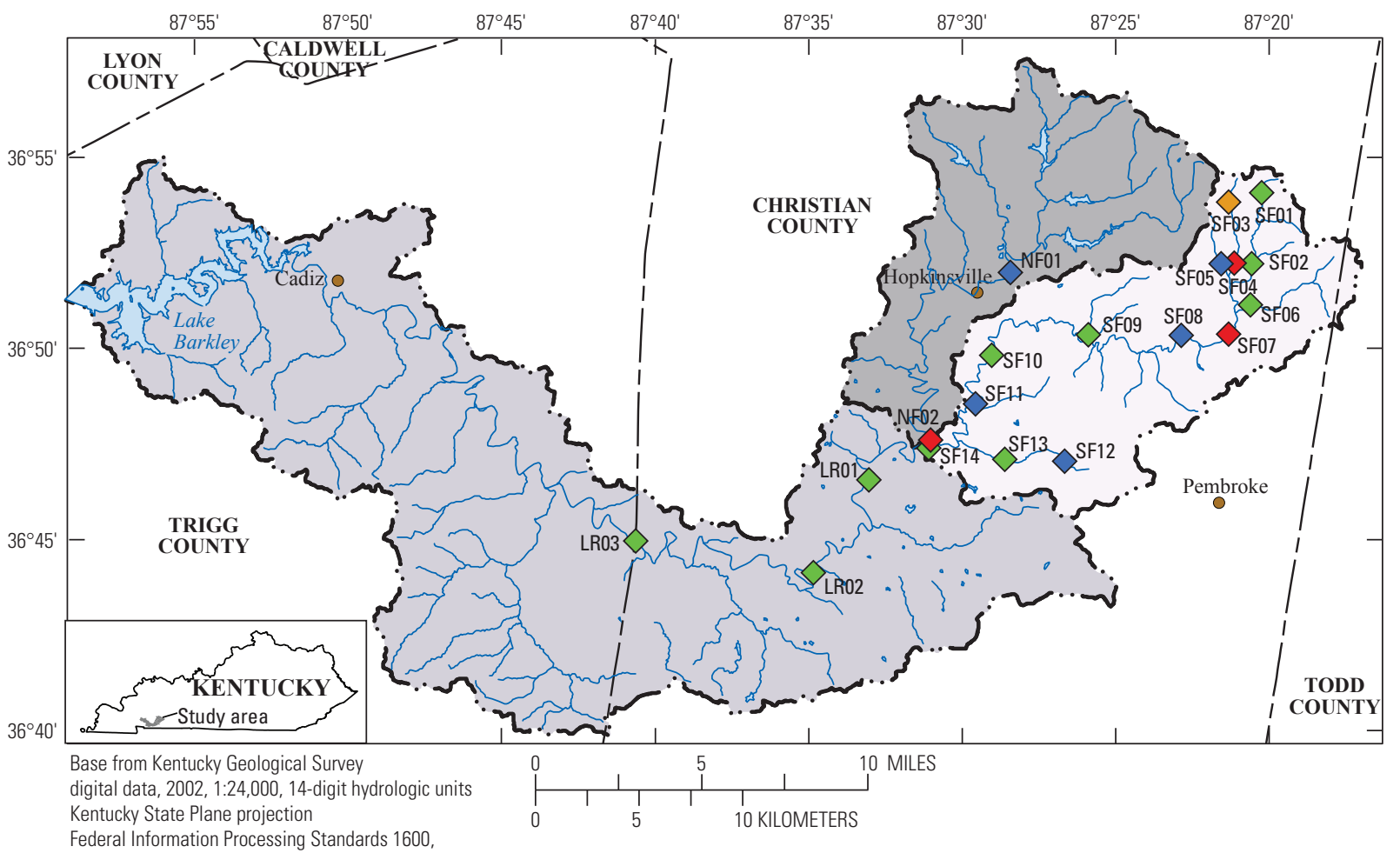

Federal Information Processing Standards 1600

United States feet, North American Datum of 1983

EXPLANATION
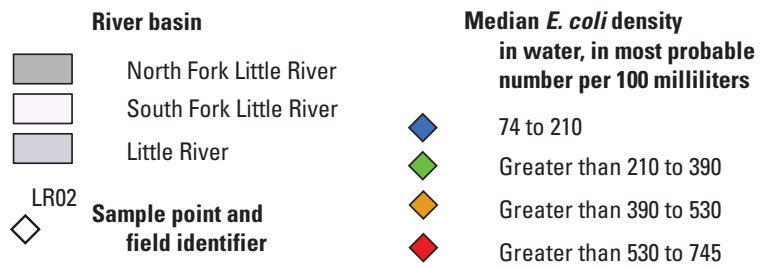

Figure 5. Distribution of E. coli densities in water samples at 19 sampling sites in the North Fork Little River, South Fork Little River, and Little River Basins, Kentucky, water years 2013-14.

and percentage land uses (table 8). No statistically significant correlations existed between median E. coli densities and any of the variables. The highest correlation was observed between $\log _{(10)}$ transformed median E. coli water density and percent pasture $(\mathrm{rho}=0.40$ and $p$-value $=0.089)$.

\section{Bacteroidales Genetic Markers}

E. coli densities can provide information on fecal contamination but do not identify the contamination source. Water samples from 11 sites were analyzed for genetic markers of warm-blooded animals in the study area. Summary statistics for the Bacteroidales markers in water samples are shown in table 9. If a value was censored, it was a left-censored data point below the qPCR detection limit, and a quantifiable number could not be generated. The detection limit changed over the study period as more data were collected and it typically decreased. It should also be noted these are individual methods for each marker, and quantified values cannot be compared between different markers, only among sites. The waterfowl marker was sampled during the first year, but because results were below the detection limit for every sample, it was discontinued during the second year. It is likely waterfowl are not a major source of continued fecal contamination in the study area.

The GenBac marker, a mixed-source marker, was above the detection limit for every sample (table 9). The highest GenBac median was from site NF02, the farthest downstream site on the NFLR before the confluence with the SFLR. The farthest downstream site on the SFLR before the confluence, site SF14, had a GenBac median that was 89 percent lower than site NF02. The median concentration of GenBac at site LR01, the first site after the confluence, was 61 percent lower than site NF02. 


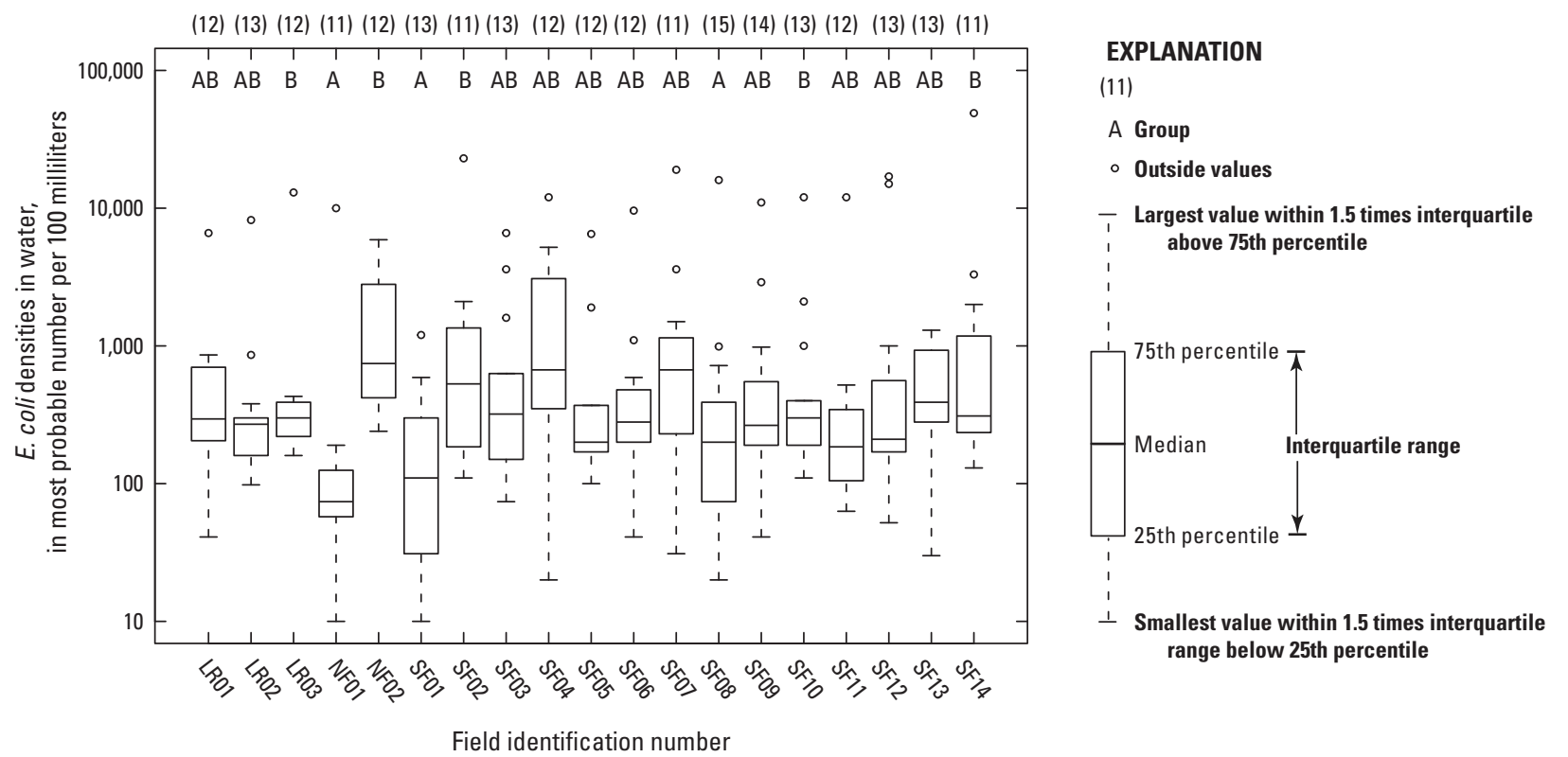

Figure 6. Median densities of E. coli in water at the 19 sampling sites throughout the Little River Basin, water years $2013-14$.

Table 7. Summary statistics of E. coli in fluvial sediment samples collected at 19 U.S. Geological Survey sites in the Little River Basin, Kentucky, April 2013-September 2013 and May 2014-November 2014.

[Concentrations in most probable number per gram dry weight sediment; >, greater than]

\begin{tabular}{|c|c|c|c|c|c|c|c|}
\hline Field identifier & Number of samples & Minimum & 25th percentile & Median & Mean & 75th percentile & Maximum \\
\hline \multicolumn{8}{|c|}{ Most probable number per gram dry weight sediment } \\
\hline NF01 & $12(0)$ & 50 & 98 & 610 & 27,900 & 1,600 & 320,000 \\
\hline NF02 & $13(0)$ & 7 & 54 & 240 & 3,160 & 700 & 35,000 \\
\hline SF01 & $12(0)$ & 9 & 42 & 61 & 141 & 102 & 970 \\
\hline SF02 & $11(1)$ & 39 & 71 & 180 & 303 & 620 & $>750$ \\
\hline SF03 & $13(0)$ & 34 & 55 & 100 & 130 & 150 & 380 \\
\hline SF04 & $10(0)$ & 44 & 130 & 150 & 308 & 240 & 1,700 \\
\hline SF05 & $11(0)$ & 1 & 40 & 75 & 736 & 340 & 5,100 \\
\hline SF06 & $13(0)$ & 13 & 73 & 260 & 472 & 930 & 1,300 \\
\hline SF07 & $13(1)$ & 45 & 190 & 420 & 2,663 & 1,000 & $>27,000$ \\
\hline SF08 & $13(1)$ & 55 & 270 & 570 & 1,451 & 3,000 & $>5,400$ \\
\hline SF09 & $13(1)$ & 120 & 510 & 960 & 1,909 & 1,800 & $>10,000$ \\
\hline SF10 & $13(0)$ & 120 & 370 & 410 & 1,220 & 1,400 & 4,200 \\
\hline SF11 & $13(0)$ & 69 & 220 & 360 & 941 & 570 & 7,400 \\
\hline SF12 & $13(1)$ & 22 & 52 & 86 & 156 & 320 & $>340$ \\
\hline SF13 & $13(1)$ & 48 & 170 & 190 & 320 & 490 & $>860$ \\
\hline SF14 & $13(1)$ & 160 & 220 & 770 & 5,120 & 2,800 & $>42,000$ \\
\hline LR01 & $13(0)$ & 16 & 220 & 370 & 4,278 & 2,200 & 42,000 \\
\hline LR02 & $13(0)$ & 29 & 88 & 130 & 10,503 & 1,200 & 5,800 \\
\hline LR03 & $13(0)$ & 54 & 130 & 320 & 904 & 690 & 6,000 \\
\hline
\end{tabular}




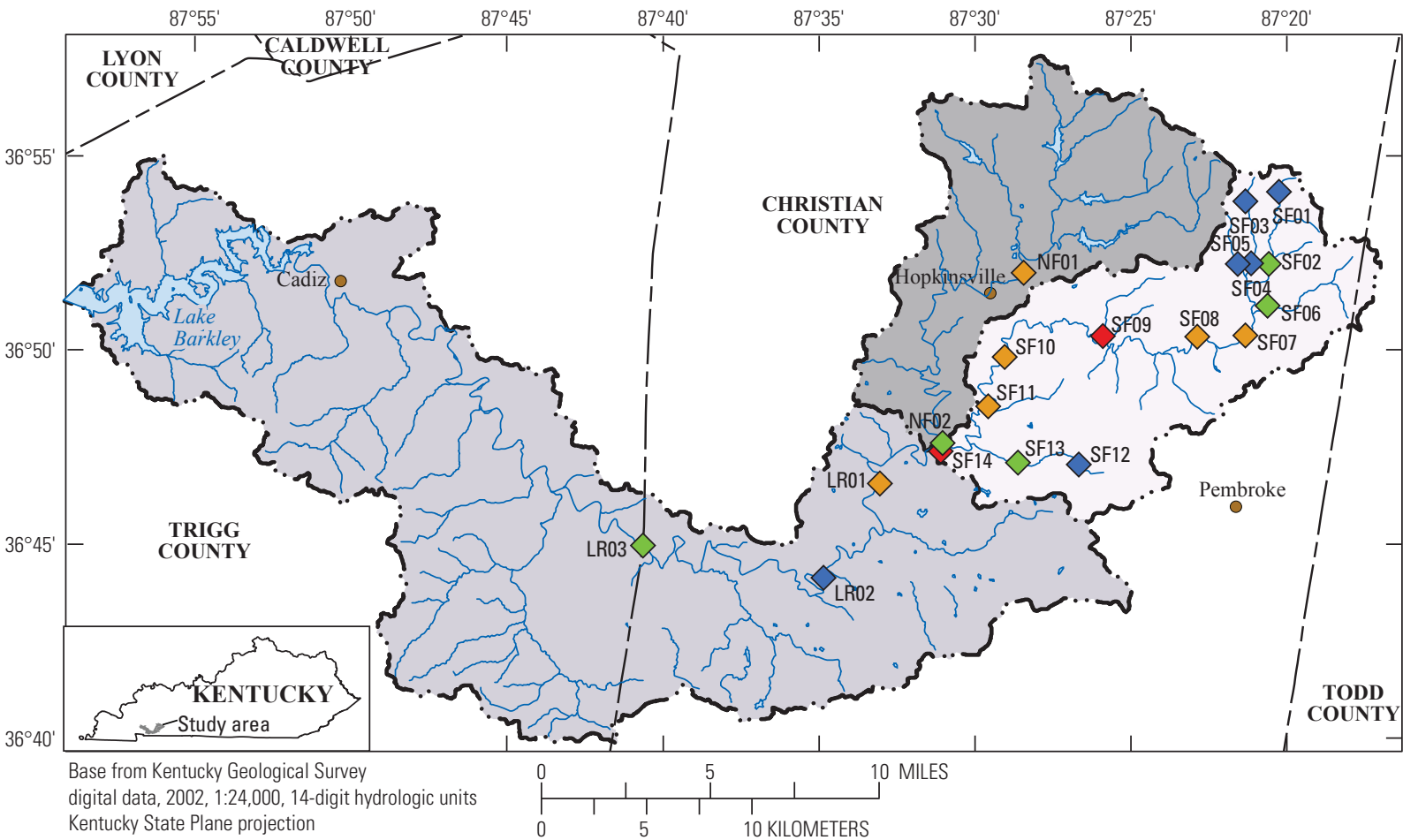

Federal Information Processing Standards 1600

United States feet, North American Datum of 1983

EXPLANATION
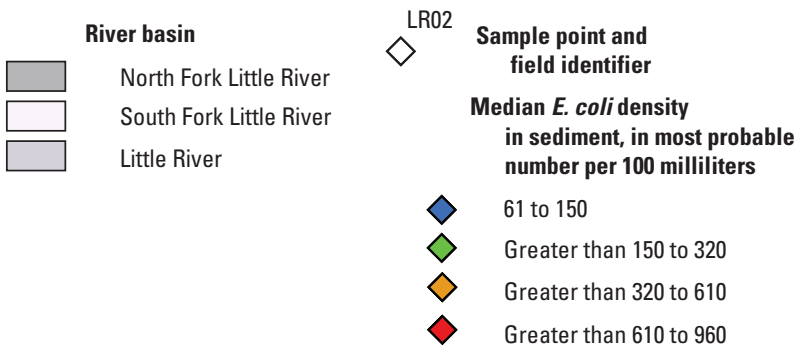

Figure 7. Median E. coli density in fluvial sediment at the 19 sampling sites throughout the Little River Basin, water years $2013-14$.

Table 8. Spearman's rank correlation test for median E. coli density in water samples, median E. coli density in fluvial sediment samples, drainage area, and land use.

[rho, Spearman rank correlation coefficient; $p$-value, probability value less than 0.05 indicates a statistically significant difference]

\begin{tabular}{|c|c|c|c|}
\hline Response variable & Explanatory variable & rho & $p$-value \\
\hline Median $\log (10) E$. coli water & $\log (10)$ percent forest & 0.163 & 0.502 \\
\hline Median $\log (10) E$. coli water & Log (10) percent developed & 0.09 & 0.713 \\
\hline Median $\log (10)$ E. coli water & Log (10) percent pasture & 0.4 & 0.089 \\
\hline Median $\log (10) E$. coli water & Log (10) percent row crop & -0.286 & 0.252 \\
\hline Median $\log (10) E$. coli water & Log (10) drainage area & -0.185 & 0.45 \\
\hline Median $\log (10)$ E. coli water & Median $\log (10)$ E. coli fluvial sediment & -0.191 & 0.437 \\
\hline Median $\log (10)$ E. coli fluvial sediment & $\log (10)$ percent forest & -0.181 & 0.457 \\
\hline Median $\log (10)$ E. coli fluvial sediment & Log (10) percent developed & 0.17 & 0.485 \\
\hline Median $\log (10)$ E. coli fluvial sediment & Log (10) percent pasture & -0.153 & 0.534 \\
\hline Median $\log (10)$ E. coli fluvial sediment & Log (10) percent row crop & 0.182 & 0.468 \\
\hline Median $\log (10)$ E. coli fluvial sediment & Log (10) drainage area & 0.191 & 0.431 \\
\hline Median $\log (10)$ E. coli fluvial sediment & Median $\log (10)$ E. coli water & -0.191 & 0.437 \\
\hline
\end{tabular}




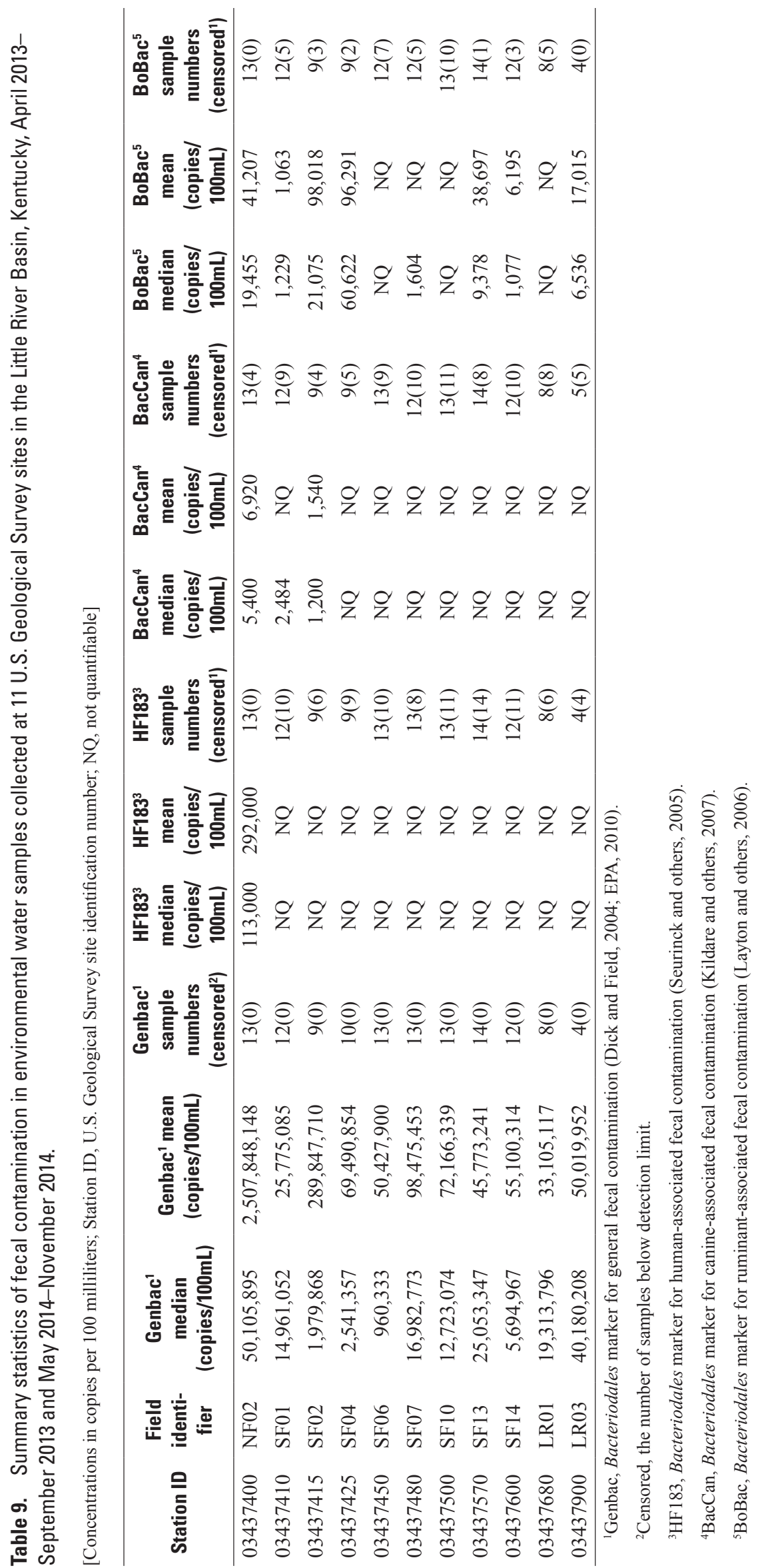


Concentrations of HF183, a human marker, were above the detection limit in 31 of 120 samples (table 9). Site NF02 was the only site where a median concentration could be computed because all sample values ( $n=13$ samples) were above the detection limit. This finding suggests humans have an influence on fecal contamination at site NF02 and this is not unexpected because the site is immediately downstream from a WWTP. Although the WWTP has a good compliance record, raw sewage has overflowed into the NFLR during high-flow events. Because of this, the WWTP is pursuing options to upgrade the capacity (J.R. Wauford and Company Consulting Engineers, Inc., and JV Engineering, Inc., 2015). The WWTP also has experienced problems with the existing siphon barrels clogging, resulting in raw sewage entering the NFLR (fig. 8) (J.R. Wauford and Company Consulting Engineers, Inc., and JV Engineering, Inc., 2015). However, the WWTP is likely not the only source of fecal contamination in the NFLR. Site NF02 is just downstream from Hopkinsville, Ky. (population of about 33,000 people). Land use in the city could contribute fecal contamination from urban runoff, leaky sewers, and (or) leaky septic tanks. Another sampling site, site SF14, is also just downstream from Hopkinsville, Ky. However, 92 percent of the samples at site SF14 were below the detection limit for the HF183 marker. Site SF10 is located within a commercial district of the city and had 85 percent of samples below the detection limit. All HF183 marker samples at sites SF04, SF13, and LR03 were below the detection limit. The percentage of HF1 183 concentrations at the four remaining SFLR Basin sites ranged from 62 to 83 percent below the detection limit. Results from the SFLR Basin suggest humans were not a major source of fecal contamination based on these samples.

Concentrations of BacCan, a canine marker, were above the detection limit in 37 of 120 samples (table 9). Medians could only be computed at sites NF02, SF01, and SF02 because those sites had enough detections. Sites LR01 and LR03 were the only two sites with every sample below the detection limit for the BacCan marker. Although contamination from canines is present in the NFLR and SFLR Basins, the BacCan marker was not detected after the confluence with the Little River. The site with the highest median BacCan marker was site NF02. As noted previously, site NF02 is just downstream from Hopkinsville, Ky., and land use in the city

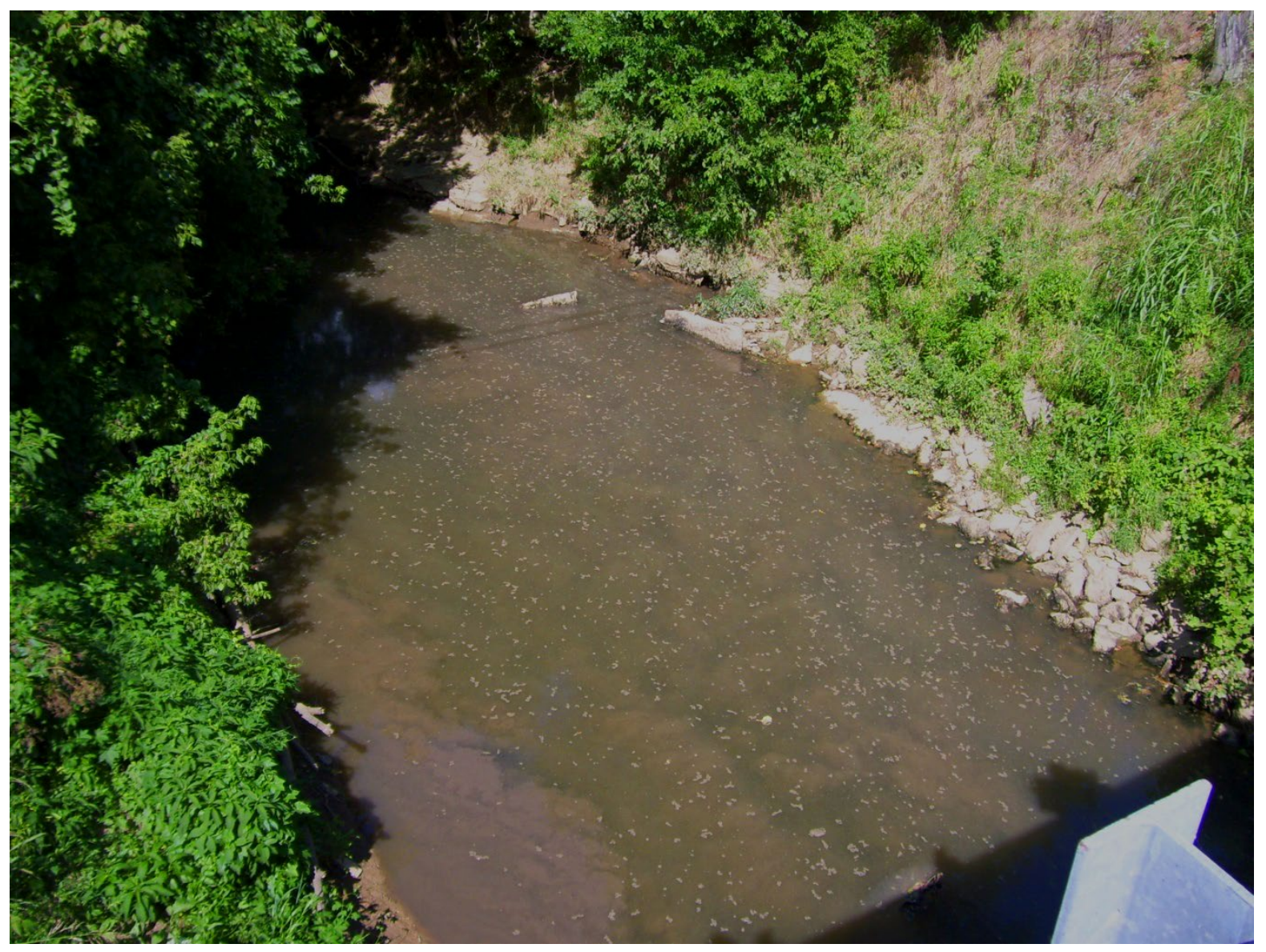

Figure 8. Sewage overflow in the North Fork Little River as seen in Hopkinsville, Kentucky, approximately 0.25 mile downstream from the overflow site. 
could contribute fecal contamination from canines. This site also had the highest median concentrations of the GenBac and HF183 markers and E. coli densities in water.

Concentrations of BoBac, the ruminant marker, were above the detection limit in 77 of 118 samples (table 9). Site SF04 had the highest BoBac median concentration. It should be noted that site SF04 has the highest percentage combination of pasture and row-crop land use ( 89 percent) along with a small drainage area (table 1). If animal manure was used as fertilizer or when cattle have direct access to this small stream (fig. 9), this could contribute to the high BoBac median concentrations.

\section{Limitations of Using Bacteroidales Genetic Markers}

Results from qPCR-detected Bacteroidales genetic markers along with traditional FIB sampling can provide important insight into the sources of fecal contamination. However, it is critical to have a good understanding of the limitations of using Bacteroidales genetic markers, and confirm the proper steps are taken to ensure defensible results. One major limitation of using Bacteroidales genetic markers is that the number of identifiable sources is limited by the existence of available Bacteroidales genetic markers for each host type.

Another limitation of Bacteroidales genetic markers is the transfer of fecal bacteria among species in close contact (for example, humans and their pets). Because genetic markers potentially can move from one species to another, host specificity must be examined when using Bacteroidales genetic markers. The host-source results of the qPCR analysis are shown in table 5, and many of the samples have quantifiable results for markers different from the host source. All the samples from the WWTP effluent had quantifiable detections of all the host markers except GFD. Because the wastewater treatment samples were untreated, these samples may have been mixed with different host sources. All the bovine-source samples had quantifiable detections of the BacCan marker. Only 2 of the 24 host-source samples collected and analyzed for the BacCan marker were below the detection limit, and both were samples from dogs. In this instance, the samples were likely not fresh, and the Bacteroidales could have died. All the host source samples were censored below the detection limit for the GFD marker.

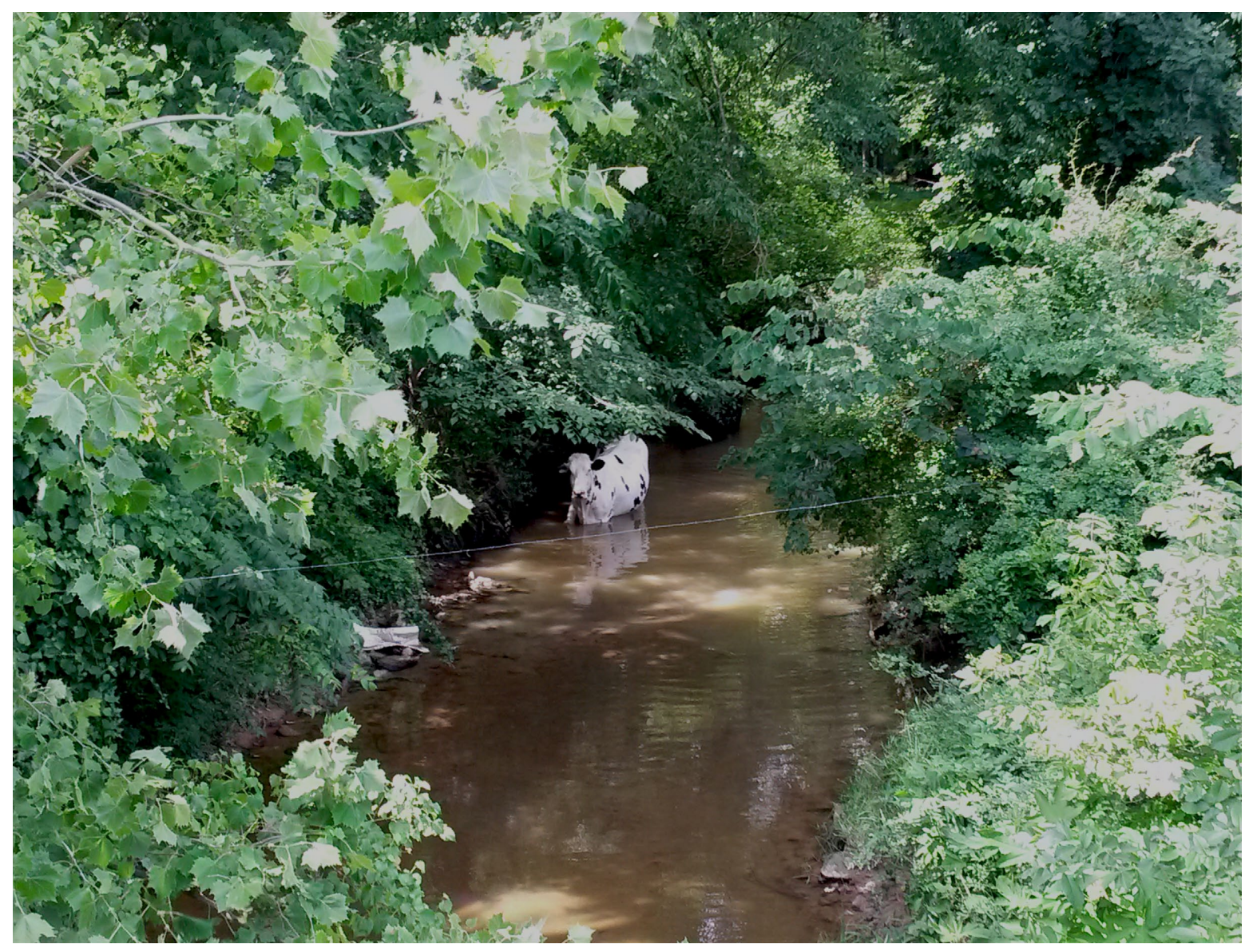

Figure 9. Cow standing in the South Fork Little River near Hopkinsville, Kentucky. 


\section{Part 3-Nutrient Water Quality and Nitrate-Source Assessment}

\author{
Lead Author: Angie S. Crain
}

Nutrients - nitrogen and phosphorus - are chemical compounds essential to life. Nutrients naturally occur in water, but factors such as artificial fertilizers, manure, and effluent from septic systems and WWTPs can increase concentrations and loads of nutrients in surface water and groundwater (Hanchar, 1991; Mueller and Helsel, 1996; Miller and Ortiz, 2007; Mahon, 2011). Elevated concentrations of nutrients can degrade the aquatic ecosystem through the growth of aquatic plants and pathogens, restrict recreational use, and potentially affect human health.

Traditional laboratory methods of measuring nitrate concentrations in surface water can provide important information on the conditions of the water quality in streams. However, these data alone do not differentiate between urban and agricultural sources of nitrate. Dual-nitrate isotopes, in combination with nutrient concentrations, can provide meaningful insights into nitrate sources and transport processes of the nitrogen cycle (Burns and others, 2009). This enables more effective implementation of best management practices in river basins.

\section{Collection and Laboratory Analysis of Nutrients, Suspended Sediment, and Dual-Nitrate Isotopes}

Discrete water-quality and suspended-sediment samples were collected monthly from October 2011 through November 2014 at 19 sites unless the streams were dry (table 1). This sampling scheme also corresponded with the dual-nitrate isotope sampling. However, fewer sites were sampled for dual-nitrate isotopes. Ten sampling sites were at key locations throughout the SFLR Basin; one sampling site was at the mouth of the NFLR Basin, and one sampling site was on the Little River main stem just below the confluence of the NFLR and SFLR. Figure 10 shows that samples were collected over a range of flow conditions which is desirable because concentrations of nitrate are commonly related to streamflow.

During periods of high streamflow, isokinetic, representative samples were collected with the equal-width-increment method (U.S. Geological Survey, variously dated). During base-flow conditions, grab samples were collected at each site. All sampling materials were constructed of Teflon ${ }^{\circledR}$ or fluorinated plastic to minimize contamination. Equipment used to collect and process water-quality and suspended-sediment samples were precleaned with a 0.1 -percent nonphosphate detergent, triple rinsed with tap water, rinsed with 5-percent hydrochloric acid for 30 minutes, triple rinsed with deionized water, air dried, and stored in a dust-free environment prior to sample collection (U.S. Geological Survey, variously dated).

Dual-nitrate isotope samples were frozen to prevent biological reaction of nitrogen-bearing species during storage and transport to the laboratory. The surface-water samples were analyzed for $\delta^{15} \mathrm{~N}_{\mathrm{NO} 3}$ and $\delta^{18} \mathrm{O}_{\mathrm{NO} 3}$ by the USGS Reston Stable Isotope Laboratory (RSIL), Reston, Virginia, using a Thermo Scientific Delta V Plus continuous-flow isotope-ratio mass spectrometer and following the Sigman-Casciotti microbial denitrifier method (Sigman and others, 2001; Casciotti and others, 2002). Briefly, denitrifying bacteria (Pseudomonas auroeofaciens) converts nitrate to gaseous nitrous oxide $\left(\mathrm{N}_{2} \mathrm{O}\right)$ for isotopic analysis. Sample analysis requires a minimum amount of $0.002 \mathrm{mg}$ of $\mathrm{NO}_{3}^{-}$as nitrogen and a minimum sample $\mathrm{NO}_{3}{ }^{-}$concentration of $0.03 \mathrm{mg} / \mathrm{L}$ as nitrogen. Stable isotopes are reported with an analytical error of less than $\pm 0.25 \%$ for $\delta^{15} \mathrm{~N}_{\mathrm{NO} 3}$ and less than $\pm 0.5 \%$ for $\delta^{18} \mathrm{O}_{\mathrm{NO} 3}$. Coplen and others (2012) provide further details on the methodology for the determination of $\delta^{15} \mathrm{~N}_{\mathrm{NO} 3}$ and $\delta^{18} \mathrm{O}_{\mathrm{NO} O}$ values in water.

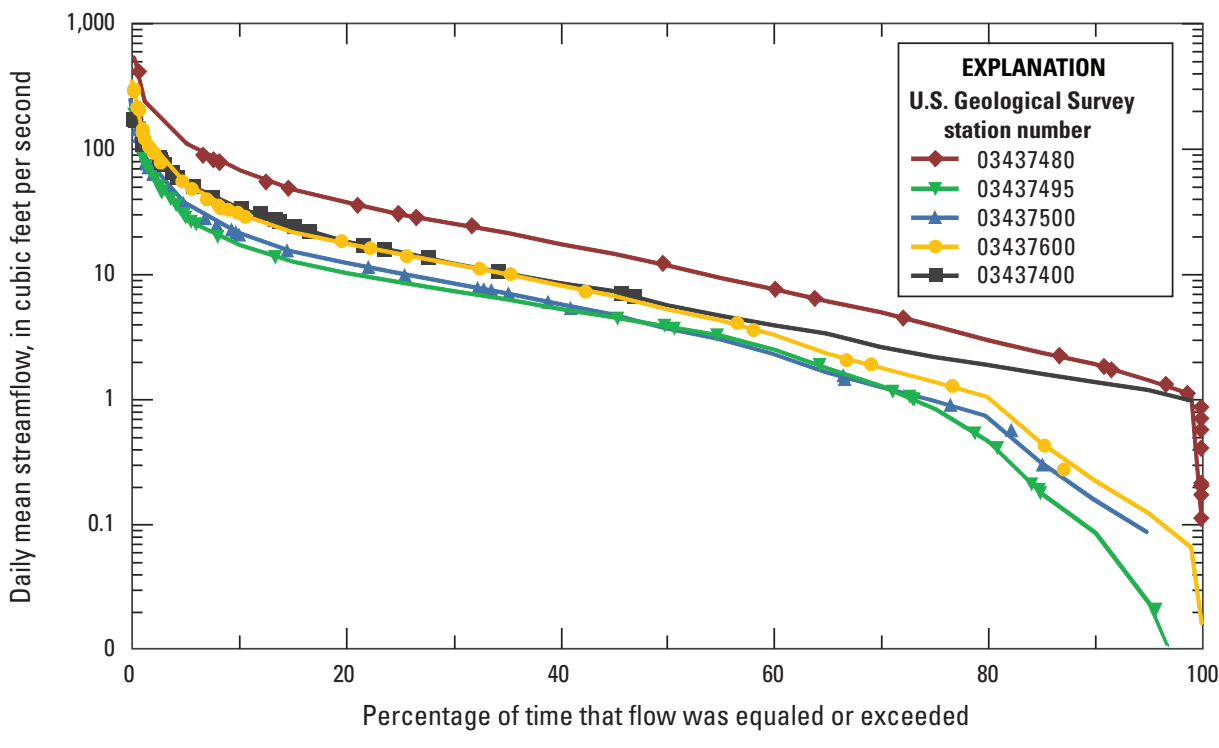

Figure 10. Duration curve of daily streamflow and sample flow exceedances at five sites, Little River Basin, Kentucky, water years 2013-14. Markers on duration curves represent the mean daily streamflow when a sample was collected. 
The parameters, laboratories, and methods used to analyze the discrete water-quality and suspended-sediment samples are listed in table 10. After analysis, data were entered into the USGS NWIS database, available online at http://waterdata.usgs.gov/nwis/.

\section{Determining Total Nitrogen Concentrations}

Total nitrogen (TN) concentrations were calculated as the sum of total ammonia plus organic nitrogen and dissolved $\mathrm{NO}_{2}+\mathrm{NO}_{3}$. Less than 1 percent of all concentrations of TN were computed using censored data. It should be noted that a positive bias can exist in the presence of elevated dissolved $\mathrm{NO}_{2}+\mathrm{NO}_{3}$ because some nitrate is reduced to ammonia and is therefore counted twice in the computation of TN (Rus and others, 2012).

\section{Estimating and Partitioning Streamflow}

The drainage-area ratio method was used to estimate daily mean streamflows for site SF14 because no daily streamflow data were available. The drainage-area ratio method is based on the assumption that the streamflow for a site of interest can be estimated by multiplying the ratio of drainagearea for the site of interest and a nearby gaging station to the streamflow of the nearby basin. This method is commonly used when an ungaged site is on the same stream (upstream or downstream) as the gaged site and the drainage-area ratio of the two sites is between 0.5 and 1.5 (Risley and others, 2008). However, the method generally is only reliable if the ungaged site is close to the gaged site. The SF14 site met the requirements because it is about $6.6 \mathrm{mi}$ downstream from the SF10 gaged streamflow site, and the drainage-area ratio between the two sites is 0.69 .

A Fortran-based computer program called PART was used in partitioning streamflow to estimate a daily record of base flow from a hydrograph (Rutledge, 1998). This program generates a BFI that represents the relative amount of streamflow from groundwater as compared to direct runoff. The BFI was calculated for four sites (SF07, SF09, SF10, and SF14) in the SFLR Basin and one site (NF02) in the NFLR Basin.

\section{Estimating Nutrient Loads and Yields}

Nutrient loads (TN, $\mathrm{NH}_{4}^{+}+$orgN, $\mathrm{NO}_{2}+\mathrm{NO}_{3}$, TP, and orthophosphorus (orthoP) were estimated using S-LOADEST, a USGS version of LOAD ESTimator (LOADEST), a FORTRAN program for estimating constituent loads in streams and rivers (Runkel and others, 2004). The USGS version is programmed for TIBCO Spotfire S+ (version 8.1), a statistical software package (TIBCO, 2008). S-LOADEST assists the user in developing a regression equation for estimating the stream load of a specific constituent. The formulated equation is then used to estimate loads on the basis of a user-defined time period. Output includes the mean load estimates, standard errors, and 95-percent confidence intervals.

S-LOADEST is based on three statistical estimation methods. The Adjusted Maximum Likelihood Estimation (AMLE) and MLE methods are appropriate when the calibration model errors (residuals) are normally distributed. If the residuals are not normally distributed and the dataset contains censored data, the AMLE and MLE methods may not be optimal. The Least Absolute Deviation is an alternative to MLE when the residuals are not normally distributed and the dataset contains no censored data (Runkel and others, 2004). For this report, the AMLE method was used for all load estimates. A complete discussion of the theory and principles behind the calibration and estimation methods can be found in Runkel and others (2004).

The S-LOADEST program contains nine predefined regression equations that can be used to estimate loads that account for different possible combinations of explanatory variables of streamflow and time (table 11). The program provides an automated selection option that selects the "best" regression equation from the set of predefined equations. However, any equation may be selected by the user, on the basis of the user's knowledge of the hydrologic and biogeochemical system of the stream. The "best" regression equation option was used for sites and constituents analyzed and presented in this report. Yields of $\mathrm{TN}, \mathrm{NH}_{4}^{+}+$orgN, $\mathrm{NO}_{2}+\mathrm{NO}_{3}, \mathrm{TP}$, and orthoP were calculated by dividing the annual loads at sites NF02, SF09, and SF14 by their respective drainage-basin area.

Table 10. Analytes for discrete water-quality and suspended sediment samples and analytical methods.

[NWQL, National Water Quality Laboratory; IN-KY WSC, Indiana-Kentucky Water Science Center; $\mathrm{NH}_{3}$, un-ionized form of ammonia; $\mathrm{NH}_{4}^{+}$, ionized form of ammonia]

\begin{tabular}{lccc}
\hline \multicolumn{1}{c}{ Analyte } & $\begin{array}{c}\text { Method } \\
\text { reporting level, } \\
\text { in milligrams per liter }\end{array}$ & Laboratory & $\begin{array}{c}\text { Reference to } \\
\text { analytical method }\end{array}$ \\
\hline${ }^{1}$ Ammonia, as nitrogen (filtered) & 0.01 & NWQL & (Fishman, 1993) \\
Ammonia plus organic nitrogen, as nitrogen (unfiltered) & 0.07 & NWQL & (Patton and Truitt, 2000) \\
Nitrite plus nitrate, as nitrogen (filtered) & 0.04 & NWQL & (Patton and Kryskalla, 2011) \\
Total phosphorus, as phosphorus (unfiltered) & 0.02 & NWQL & (Patton and Truitt, 1992) \\
Orthophosphorus, as phosphorus (filtered) & 0.004 & NWQL & (Fishman, 1993) \\
Suspended sediment & 1.0 & IN-KY WSC & (ASTM, 2006) \\
\end{tabular}

${ }^{1} \mathrm{Ammonia}$, as nitrogen (filtered) reported as total ammonia $\left(\mathrm{NH}_{3}+\mathrm{NH}_{4}^{+}\right)$. 
Table 11. Predefined regression equations in the LOADEST computer program for estimating loads in rivers and streams.

[Ln, natural logarithm (log) of the estimated load; $\beta$ n, estimated coefficients; $Q, \log$ of the streamflow; $\mathrm{T}^{*}$, centered time in decimal years; sin, sine; $\cos , \operatorname{cosine} ; \pi, \mathrm{pi} ; \mathrm{T}$, fraction of the year in decimal years]

\begin{tabular}{cl}
$\begin{array}{c}\text { Regression } \\
\text { equation number }\end{array}$ & \multicolumn{1}{c}{ Equation description } \\
\hline 1 & $\mathrm{~L}=\beta_{0}+\beta_{1} \mathrm{LnQ}$ \\
2 & $\mathrm{~L}=\beta_{0}+\beta_{1} \mathrm{LnQ}+\beta_{2} \mathrm{LnQ}^{2}$ \\
3 & $\mathrm{~L}=\beta_{0}+\beta_{1} \mathrm{LnQ}+\beta_{2} \mathrm{~T}^{*}$ \\
4 & $\mathrm{~L}=\beta_{0}+\beta_{1} \mathrm{LnQ}+\beta_{2} \sin (2 \pi \mathrm{T})+\beta_{3} \cos (2 \pi \mathrm{T})$ \\
5 & $\mathrm{~L}=\beta_{0}+\beta_{1} \mathrm{LnQ}+\beta_{2} \mathrm{Q}^{2}+\beta_{3} \mathrm{~T}^{*}$ \\
6 & $\mathrm{~L}=\beta_{0}+\beta_{1} \mathrm{LnQ}+\beta_{2} \mathrm{LnQ} \mathrm{Q}^{2}+\beta_{3} \sin (2 \pi \mathrm{T})+\beta_{4} \cos (2 \pi \mathrm{T})$ \\
7 & $\mathrm{~L}=\beta_{0}+\beta_{1} \mathrm{LnQ}+\beta_{2} \sin (2 \pi \mathrm{T})+\beta_{3} \cos (2 \pi \mathrm{T})+\beta_{4} \mathrm{~T}^{*}$ \\
8 & $\mathrm{~L}=\beta_{0}+\beta_{1} \mathrm{LnQ}+\beta_{2} \mathrm{LnQ}^{2}+\beta_{3} \sin (2 \pi \mathrm{T})+\beta_{4} \cos (2 \pi \mathrm{T})+\beta_{5} \mathrm{~T}^{*}$ \\
9 & $\mathrm{~L}=\beta_{0}+\beta_{1} \mathrm{LnQ}+\beta_{2} \mathrm{LnQ}^{2}+\beta_{3} \sin (2 \pi \mathrm{T})+\beta_{4} \cos (2 \pi \mathrm{T})+\beta_{5} \mathrm{~T}^{*}+\beta_{6} \mathrm{~T}^{* 2}$ \\
\hline
\end{tabular}

\section{Statistical Analysis of Nutrient Data}

The Spearman rank correlation test was used to determine the degree of correlation between nutrient concentration data and stream flow, as well as between nitrate concentrations and dual-nitrate isotope values, with the null hypothesis being that no correlation exists. Spearman's rho was computed on the ranks of the data. Rho values vary between -1 and +1 ; values closer to -1 indicate an inverse correlation, and values closer to +1 indicate a positive correlation. Rho values close to zero indicate no correlation (Helsel and Hirsch, 2002). A significance level (alpha value) of 0.05 was used for all statistical tests. The significance level is the probability ( $p$-value) of incorrectly rejecting the null hypothesis.

\section{Results of Nutrient Water Quality}

Summary statistics for the concentrations of nutrients $\left(\mathrm{NH}_{4}^{+}+\right.$orgN, $\mathrm{NO}_{2}+\mathrm{NO}_{3}, \mathrm{TP}$, and orthoP) from water years 2013 and 2014 at 19 sampling sites are shown in table 12. These data provide the basis for analysis of concentrations and estimated loads and yields at select sampling sites. Load regression models and variable coefficients are summarized for $\mathrm{NH}_{4}^{+}+\operatorname{orgN}, \mathrm{NO}_{2}+\mathrm{NO}_{3}, \mathrm{TP}$, and orthoP at select sites. Annual loads and yields for the above constituents are presented.

\section{Concentrations of Nutrients}

Concentrations of TN in surface-water samples ranged from 0.26 to $18.0 \mathrm{mg} / \mathrm{L}$ for the 14 sampling sites in the SFLR Basin (table 12, fig. 11). Median concentrations of TN in the SFLR Basin ranged from 0.51 to $9.25 \mathrm{mg} / \mathrm{L}$ as nitrogen (N) (table 12, fig. 12). Concentrations of TN ranged from 1.06 to $16.98 \mathrm{mg} / \mathrm{L}$ as $\mathrm{N}$ for the two sites in the NFLR Basin (table 12, fig. 11). Median concentrations of TN in the NFLR Basin were lowest $(1.92 \mathrm{mg} / \mathrm{L}$ as N) upstream at site NF01 and highest (3.65 mg/L as N) downstream at site NF02 (fig. 12). Concentrations of $\mathrm{TN}$ at sites on the Little River ranged from 2.50 to $11.72 \mathrm{mg} / \mathrm{L}$ as $\mathrm{N}$; both values were observed at site LR01. Median concentrations of TN at the Little River sites ranged from $4.47 \mathrm{mg} / \mathrm{L}$ as $\mathrm{N}$ at site LR01 to $4.89 \mathrm{mg} / \mathrm{L}$ as N at site LR02. The majority of TN concentrations were above the EPA recommended criteria of $0.69 \mathrm{mg} / \mathrm{L}$ as $\mathrm{N}$ for the nutrient ecoregion IX (U.S. Environmental Protection Agency, 2000). Concentrations of TN exceeded the recommended criteria in about 90 percent of the samples collected in the SFLR Basin. All TN concentrations in the NFLR Basin were above the EPA recommended criteria. Concentrations of nitrate comprised 76 percent of the median TN concentration for all sites.

Elevated total ammonia $\left(\mathrm{NH}_{3}+\mathrm{NH}_{4}^{+}\right)$concentrations in streams may increase concentrations of un-ionized ammonia $\left(\mathrm{NH}_{3}\right)$, which can kill fish and other aquatic life. The Commonwealth of Kentucky ammonia toxicity criteria are established according to un-ionized ammonia concentrations and are a function of water temperature and $\mathrm{pH}$ (Kentucky Administrative Regulations, 2008). However, only concentrations of total ammonia $\left(\mathrm{NH}_{3}+\mathrm{NH}_{4}^{+}\right)$were measured in this study. Concentrations of $\mathrm{NH}_{3}+\mathrm{NH}_{4}^{+}$in surface-water samples ranged from $<0.01$ to $3.03 \mathrm{mg} / \mathrm{L}$ as $\mathrm{N}$ for all sampling sites in the SFLR Basin (table 12, fig. 11). Median concentrations of $\mathrm{NH}_{3}+\mathrm{NH}_{4}^{+}$ranged from $<0.01$ to $0.04 \mathrm{mg} / \mathrm{L}$ as N (fig. 13). Site NF01 had both the lowest $(<0.01 \mathrm{mg} / \mathrm{L}$ as N$)$ and highest $\left(2.62 \mathrm{mg} / \mathrm{L}\right.$ as N) concentrations of $\mathrm{NH}_{3}+\mathrm{NH}_{4}^{+}$in the NFLR Basin (table 12, fig. 11). Median concentrations of $\mathrm{NH}_{3}+\mathrm{NH}_{4}^{+}$ ranged from $0.10 \mathrm{mg} / \mathrm{L}$ as $\mathrm{N}$ at site $\mathrm{NF} 01$ to $0.35 \mathrm{mg} / \mathrm{L}$ as N at site NF02 (fig. 13). Concentrations of $\mathrm{NH}_{3}+\mathrm{NH}_{4}^{+}$at the Little River sites ranged from $<0.01 \mathrm{mg} / \mathrm{L}$ as $\mathrm{N}$ at sites LR02 and LR03 to $2.17 \mathrm{mg} / \mathrm{L}$ as $\mathrm{N}$ at site LR01. Median concentrations of $\mathrm{NH}_{3}+\mathrm{NH}_{4}^{+}$at the Little River sites ranged from $0.03 \mathrm{mg} / \mathrm{L}$ as $\mathrm{N}$ at site $\mathrm{LR} 03$ to $0.12 \mathrm{mg} / \mathrm{L}$ as $\mathrm{N}$ at site LR01. 


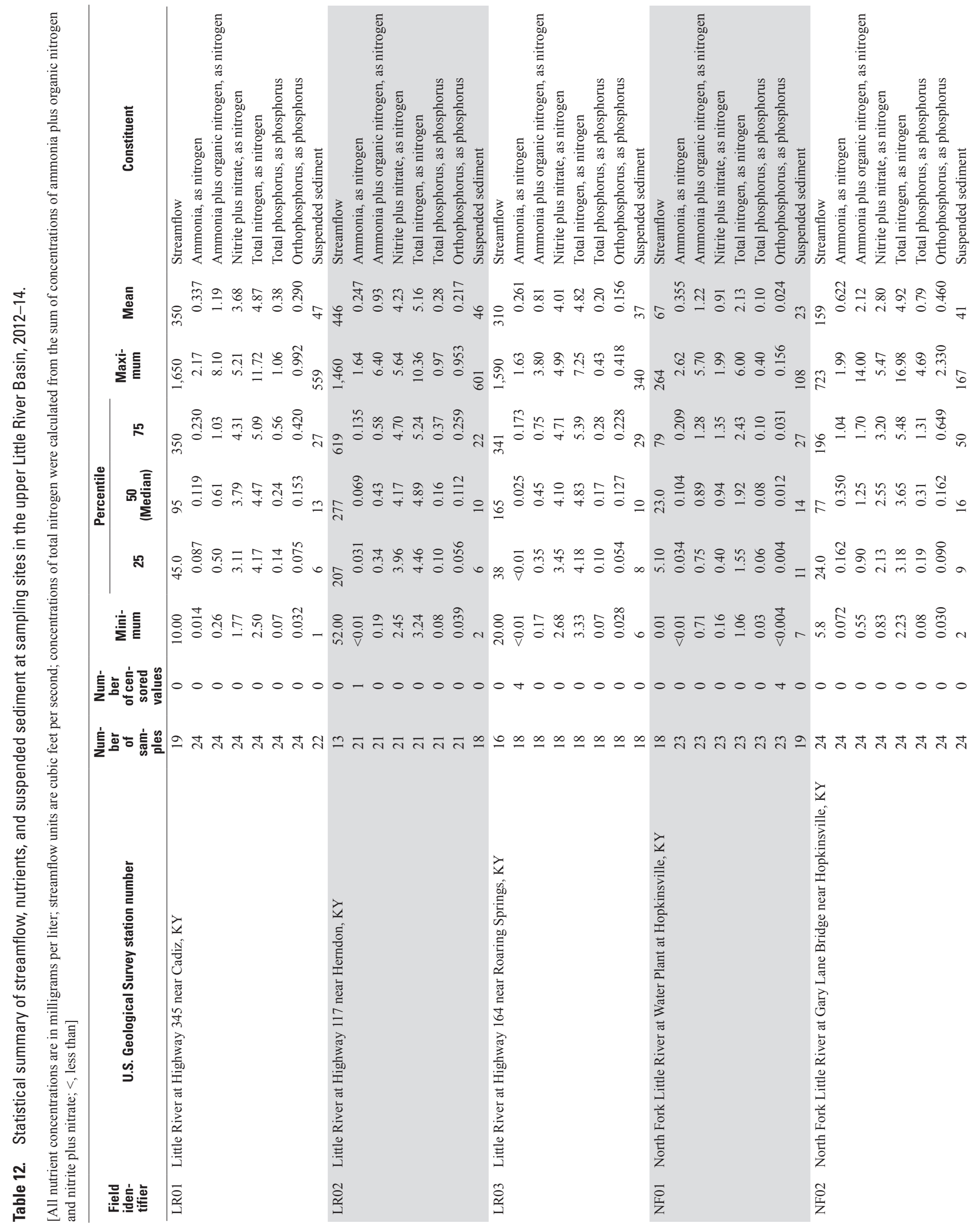




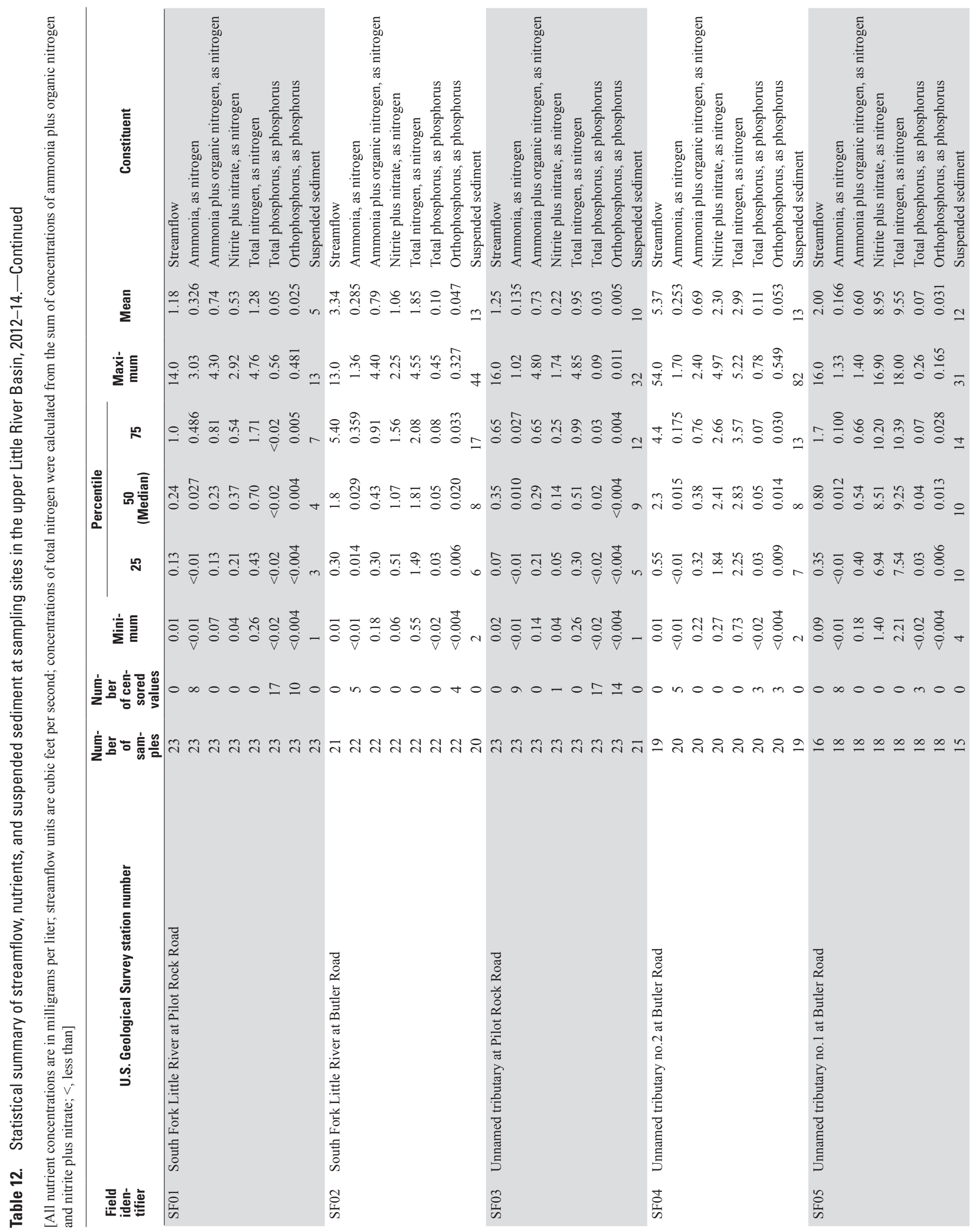




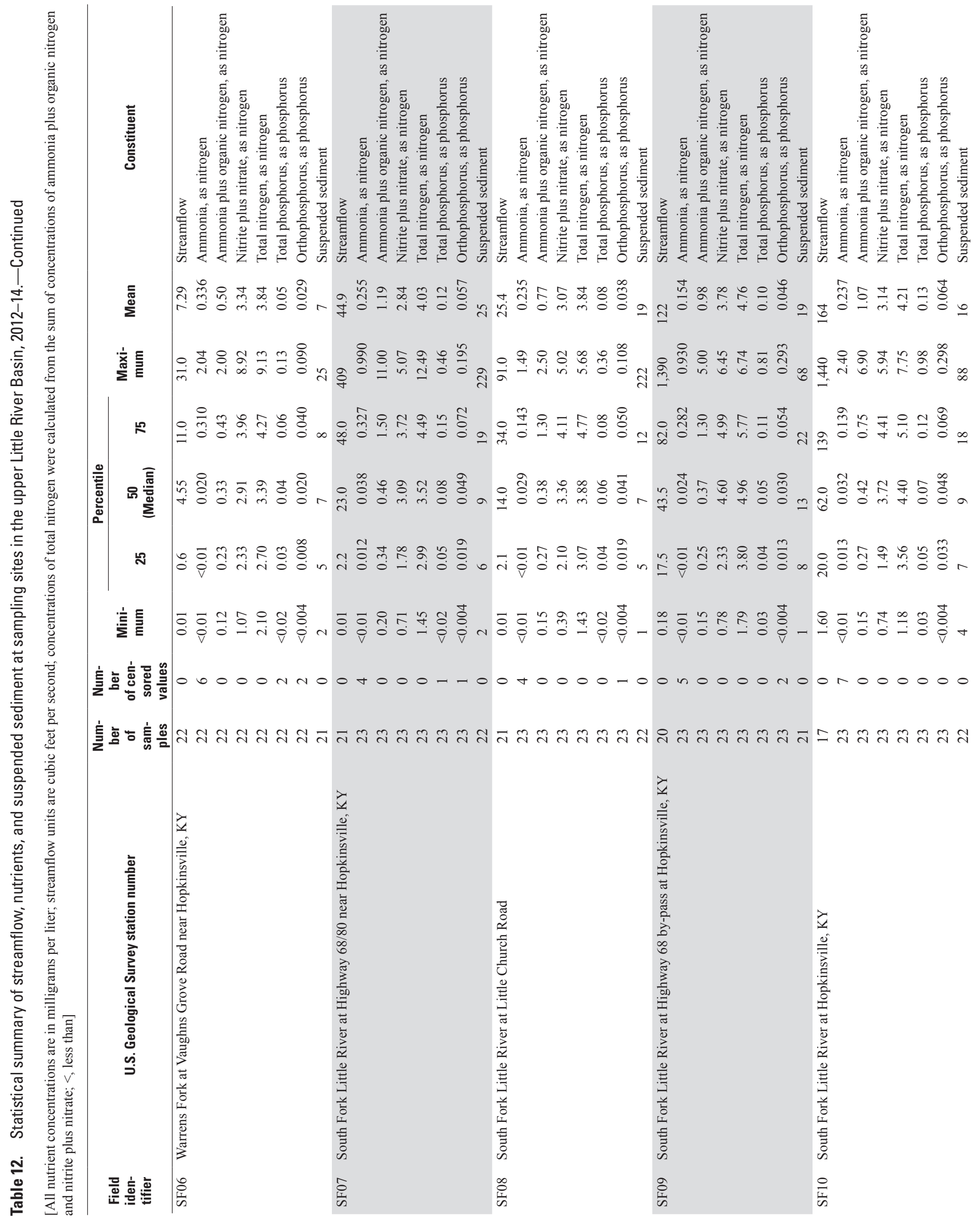




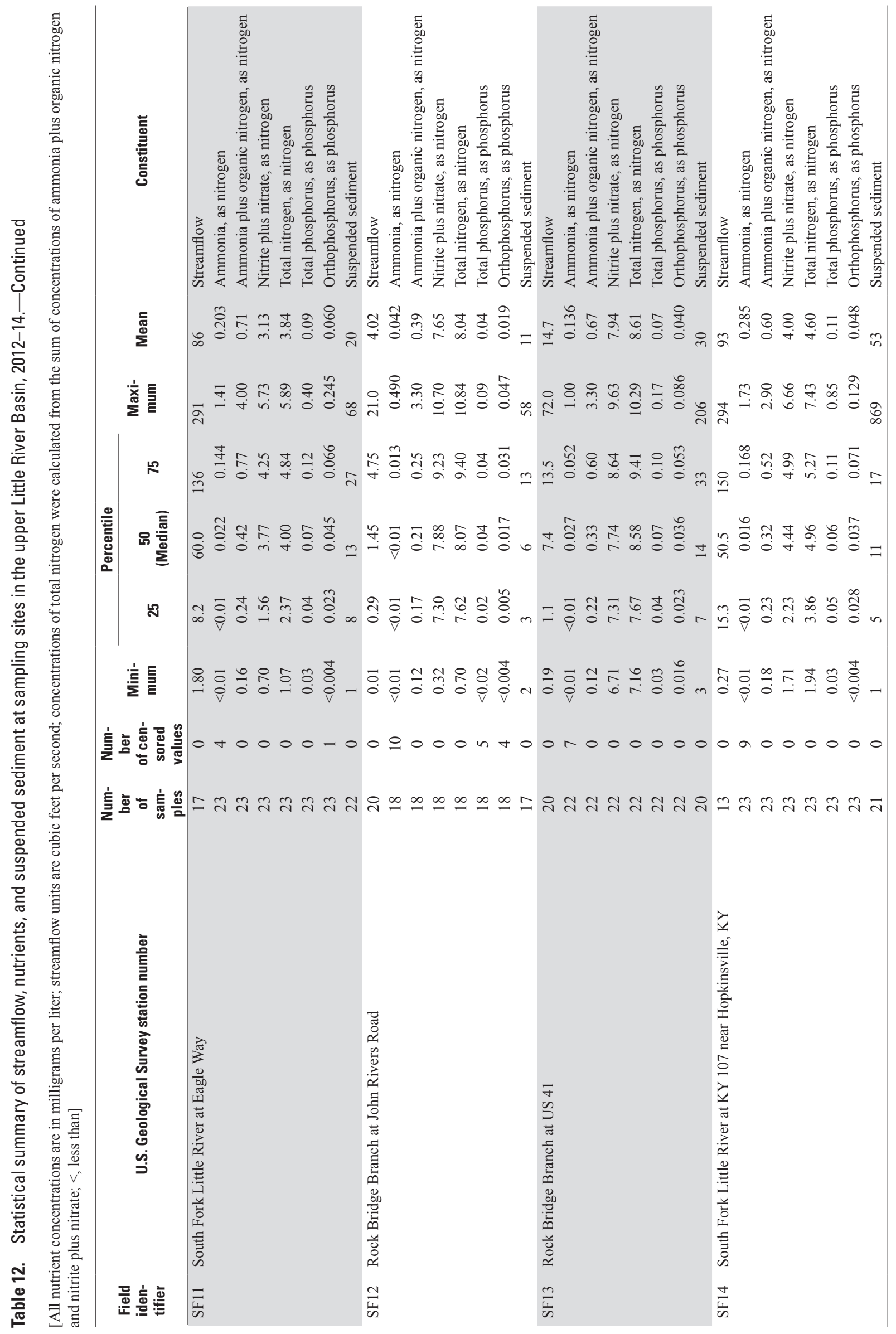



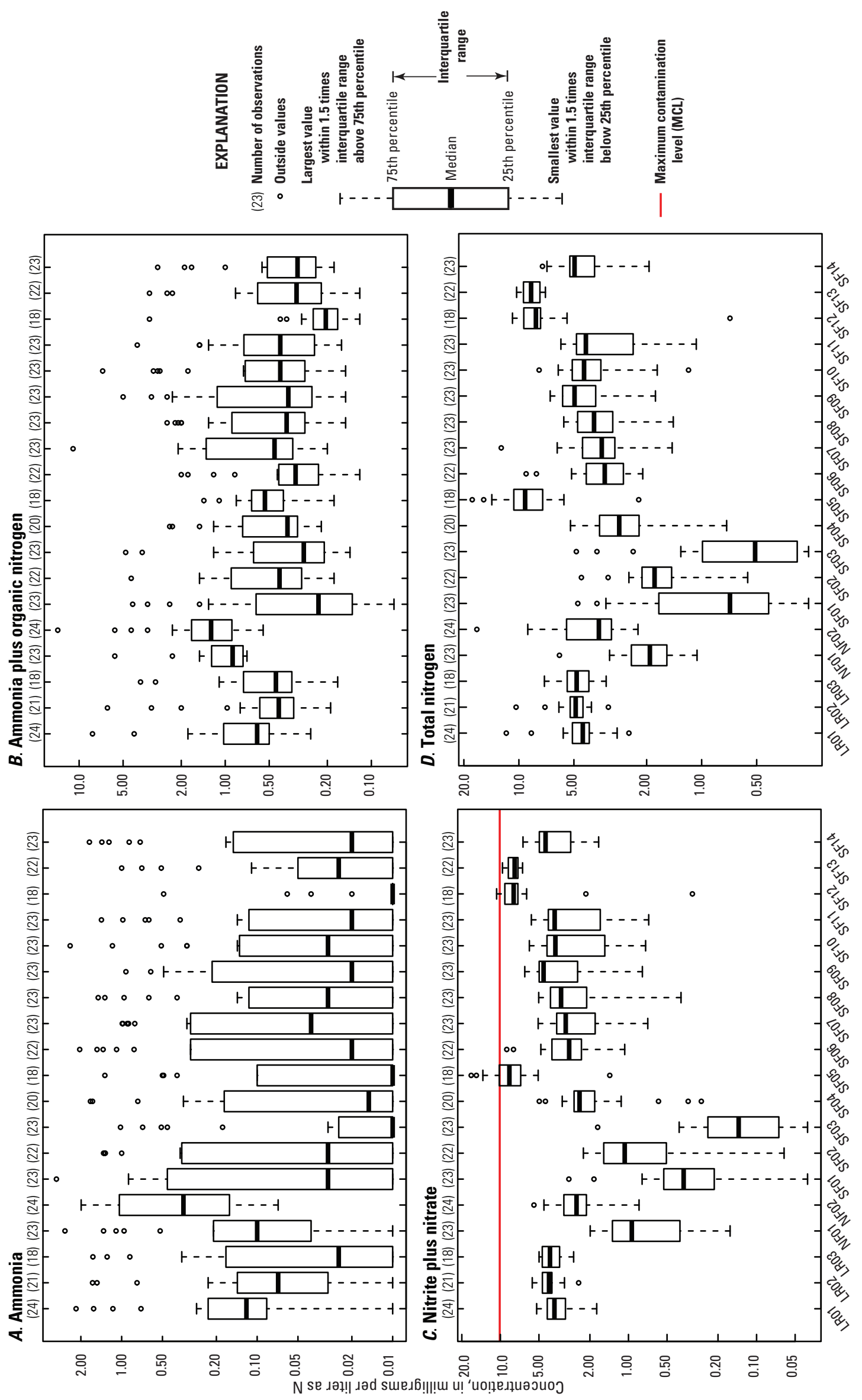

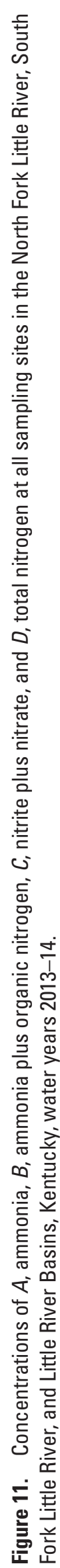




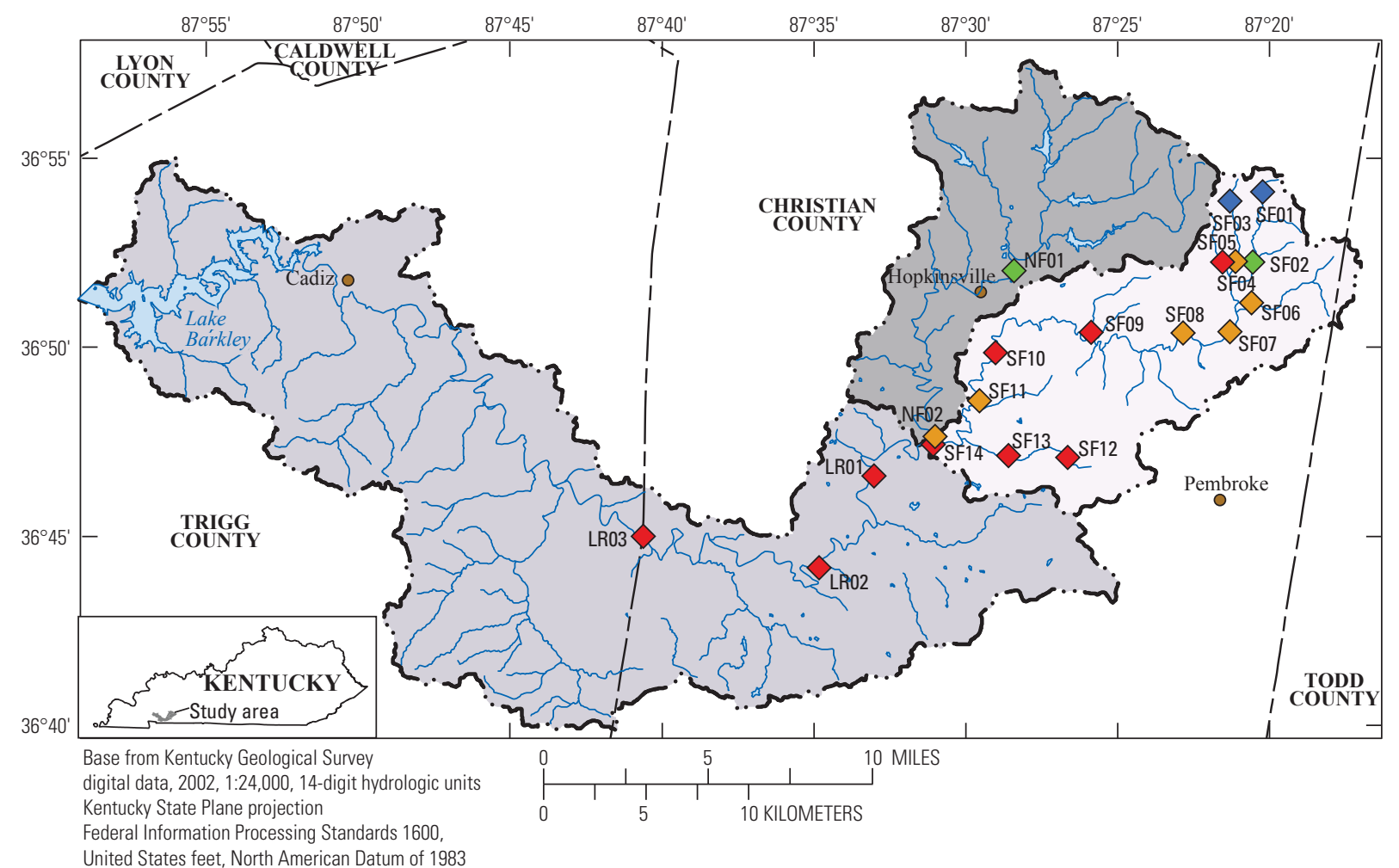

EXPLANATION

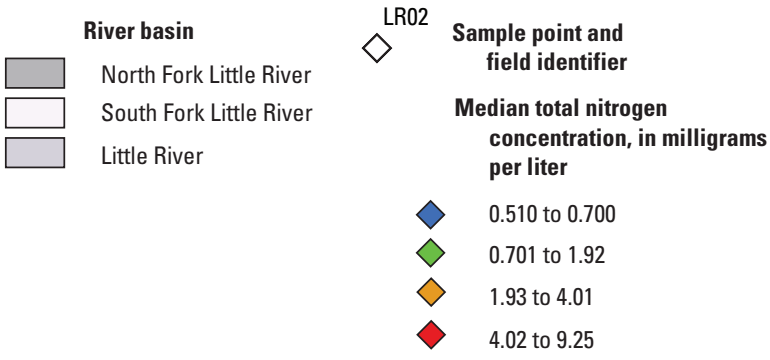

Figure 12. Median concentrations of total nitrogen at the 19 sampling sites in the North Fork Little River, South Fork Little River, and Little River Basins, Kentucky, water years 2013-14.

Concentrations of ammonia plus organic nitrogen $\left(\mathrm{NH}_{4}^{+}+\right.$orgN) ranged from 0.07 to $11.0 \mathrm{mg} / \mathrm{L}$ as $\mathrm{N}$ in the SFLR Basin (table 12, fig. 11). Median concentrations of $\mathrm{NH}_{4}^{+}+$orgN ranged from 0.21 to $0.54 \mathrm{mg} / \mathrm{L}$ as $\mathrm{N}$ in the SFLR Basin (fig. 14). Site NF02 in the NFLR Basin had the lowest $(0.55 \mathrm{mg} / \mathrm{L}$ as $\mathrm{N})$ and highest $(14.0 \mathrm{mg} / \mathrm{L}$ as $\mathrm{N})$ concentrations of $\mathrm{NH}_{4}^{+}+\operatorname{orgN}$ (table 12, fig. 11). Median concentrations of $\mathrm{NH}_{4}^{+}+\operatorname{orgN}$ in the NFLR Basin were $0.89 \mathrm{mg} / \mathrm{L}$ as $\mathrm{N}$ at site $\mathrm{NF} 01$ and $1.25 \mathrm{mg} / \mathrm{L}$ as $\mathrm{N}$ at site NF02 (fig. 14). Concentrations of ammonia $\left(\mathrm{NH}_{3}+\mathrm{NH}_{4}^{+}\right)$represented about 30 percent of the $\mathrm{NH}_{4}^{+}+\operatorname{orgN}$ in both basins, indicating organic nitrogen is the dominant nitrogen species. Sample concentrations of $\mathrm{NH}_{4}^{+}+\operatorname{orgN}$ represented 46 percent of the TN concentrations in the NFLR Basin and 26 percent in the SFLR Basin. Concentrations of $\mathrm{NH}_{4}^{+}+$orgN at the Little River sites ranged from $0.17 \mathrm{mg} / \mathrm{L}$ as $\mathrm{N}$ at site LR03 to $8.10 \mathrm{mg} / \mathrm{L}$ as $\mathrm{N}$ at site LR01. Median concentrations of $\mathrm{NH}_{4}^{+}+$orgN at the Little River sites ranged from $0.43 \mathrm{mg} / \mathrm{L}$ as $\mathrm{N}$ at site $\mathrm{LR} 02$ to $0.61 \mathrm{mg} / \mathrm{L}$ as $\mathrm{N}$ at site LR01.

Concentrations of nitrite plus nitrate $\left(\mathrm{NO}_{2}+\mathrm{NO}_{3}\right)$ in surface-water samples ranged from 0.04 to $16.90 \mathrm{mg} / \mathrm{L}$ as $\mathrm{N}$ for sites in the SFLR Basin (table 12, fig. 11). Median concentrations of $\mathrm{NO}_{2}+\mathrm{NO}_{3}$ ranged from 0.14 to $8.51 \mathrm{mg} / \mathrm{L}$ as $\mathrm{N}$ in the SFLR Basin (fig. 15). Concentrations of $\mathrm{NO}_{2}+\mathrm{NO}_{3}$ at sites in the NFLR Basin were lowest $(0.16 \mathrm{mg} / \mathrm{L}$ as N) at site $\mathrm{NF} 01$ and highest $(5.47 \mathrm{mg} / \mathrm{L}$ as $\mathrm{N}$ ) at site NF02 (table 12, fig. 11). Median concentrations of $\mathrm{NO}_{2}+\mathrm{NO}_{3}$ in the NFLR Basin were $0.94 \mathrm{mg} / \mathrm{L}$ as $\mathrm{N}$ at site NF01 and $2.55 \mathrm{mg} / \mathrm{L}$ as $\mathrm{N}$ at site $\mathrm{NF02}$ (fig. 15). Concentrations of $\mathrm{NO}_{2}+\mathrm{NO}_{3}$ at the Little River sites ranged from $1.77 \mathrm{mg} / \mathrm{L}$ as $\mathrm{N}$ at site LR01 to 5.64 $\mathrm{mg} / \mathrm{L}$ as $\mathrm{N}$ at site LR02. Median concentration of $\mathrm{NO}_{2}+\mathrm{NO}_{3}$ at the Little River sites ranged from $3.79 \mathrm{mg} / \mathrm{L}$ as $\mathrm{N}$ at site LR01 to $4.17 \mathrm{mg} / \mathrm{L}$ as $\mathrm{N}$ at site $\mathrm{LR} 02$. Concentrations of $\mathrm{NO}_{2}+\mathrm{NO}_{3}$ 

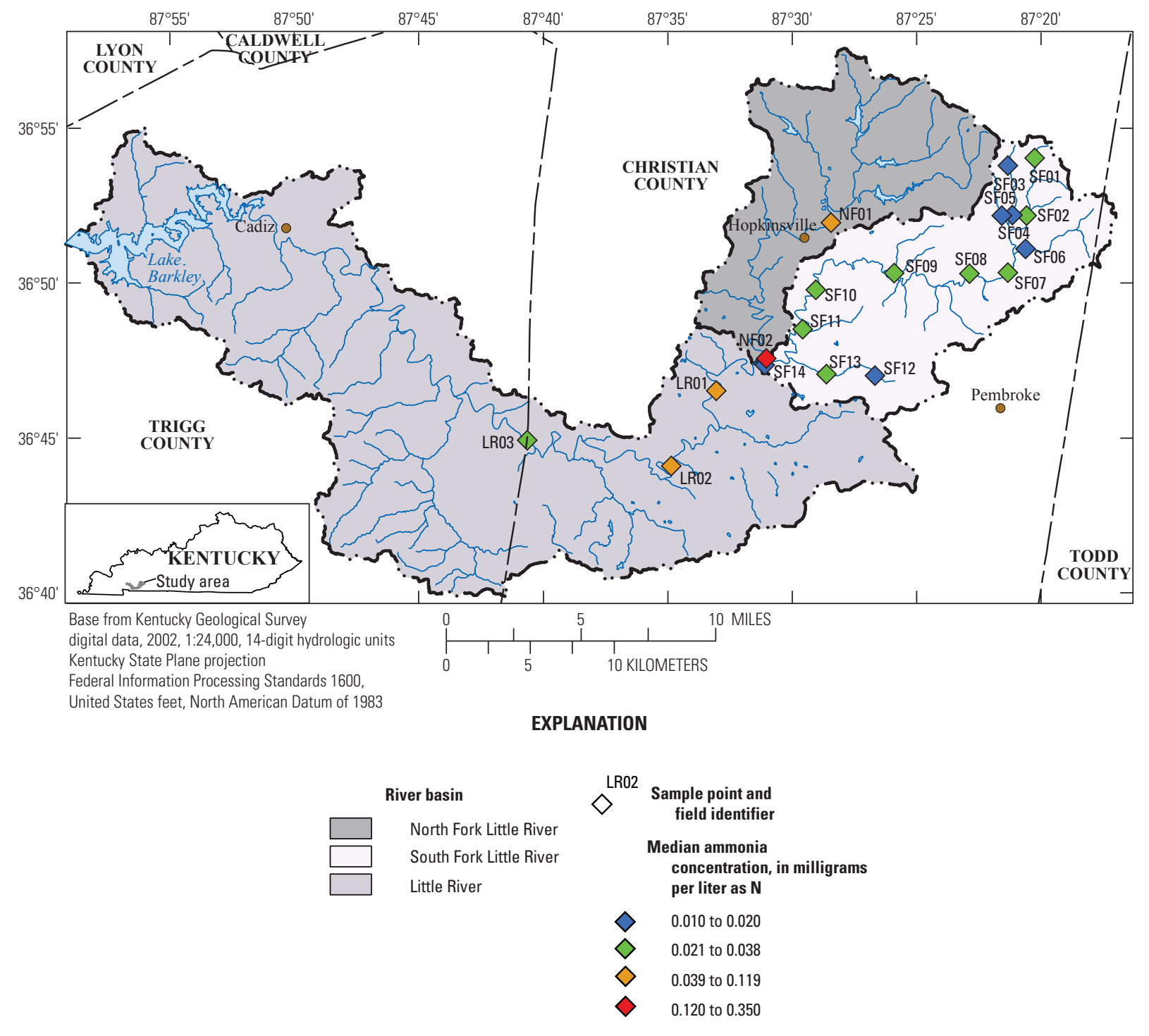

Figure 13. Median concentrations of ammonia $\left(\mathrm{NH}_{3}+\mathrm{NH}_{4}{ }^{+}\right)$at the 19 sampling sites in the North Fork Little River, South Fork Little River, and Little River Basins, Kentucky, water years 2013-14.

in about 98 percent of all collected samples were less than the EPA drinking-water standard of $10 \mathrm{mg} / \mathrm{L}$.

Concentrations of total phosphorus (TP) in surface-water samples ranged from $<0.02$ to $0.98 \mathrm{mg} / \mathrm{L}$ as $\mathrm{P}$ in the SFLR Basin (table 12, fig. 16). Median concentrations of TP ranged from $<0.02$ to $0.08 \mathrm{mg} / \mathrm{L}$ as $\mathrm{P}$ in the SFLR Basin (table 12 , fig. 17). Surface-water concentrations of TP in the NFLR Basin ranged from $0.03 \mathrm{mg} / \mathrm{L}$ as $\mathrm{P}$ at the upstream site NF01 to $4.69 \mathrm{mg} / \mathrm{L}$ as $\mathrm{P}$ at the downstream site NF02 (table 12 , fig. 16). Median concentrations of TP in the NFLR Basin were $0.08 \mathrm{mg} / \mathrm{L}$ as $\mathrm{P}$ at site $\mathrm{NF} 01$ and $0.31 \mathrm{mg} / \mathrm{L}$ as $\mathrm{P}$ at site $\mathrm{NF} 02$ (fig. 17). Concentrations of TP at the Little River sites ranged from $0.07 \mathrm{mg} / \mathrm{L}$ as $\mathrm{P}$ at sites LR01 and LR03 to $1.06 \mathrm{mg} / \mathrm{L}$ as $\mathrm{P}$ at site LR01. Median concentrations of TP ranged from $0.16 \mathrm{mg} / \mathrm{L}$ as $P$ at site $\mathrm{LR} 02$ to $0.24 \mathrm{mg} / \mathrm{L}$ as $P$ at site LR01. Sixty-nine percent of the concentrations of TP were less than
$0.1 \mathrm{mg} / \mathrm{L}$ as $\mathrm{P}$, which is the EPA target goal to prevent nuisance plant growth in streams. The EPA target goal concentration of $0.1 \mathrm{mg} / \mathrm{L}$ of $\mathrm{P}$ was exceeded in 31 percent of all samples. The concentrations of TP exceeded the EPA target goal in 38 percent of all NFLR Basin samples, 11 percent of all SFLR Basin samples, and 43 percent of all Little River main-stem samples (Hopkinsville to the Christian/Trigg County line) (fig. 1). Concentrations of TP greater than $0.1 \mathrm{mg} / \mathrm{L}$ as P might be considered evidence of anthropogenic activities. The majority of TP concentrations were above the EPA recommended criteria of $0.037 \mathrm{mg} / \mathrm{L}$ as P for the nutrient ecoregion IX (U.S. Environmental Protection Agency, 2000). Concentrations of TP exceeded the recommended criteria in 67 percent of all samples in the SFLR Basin and 98 percent of all samples in the NFLR Basin. Concentrations of orthoP comprised 47 percent of the median TP concentration for all sites. 

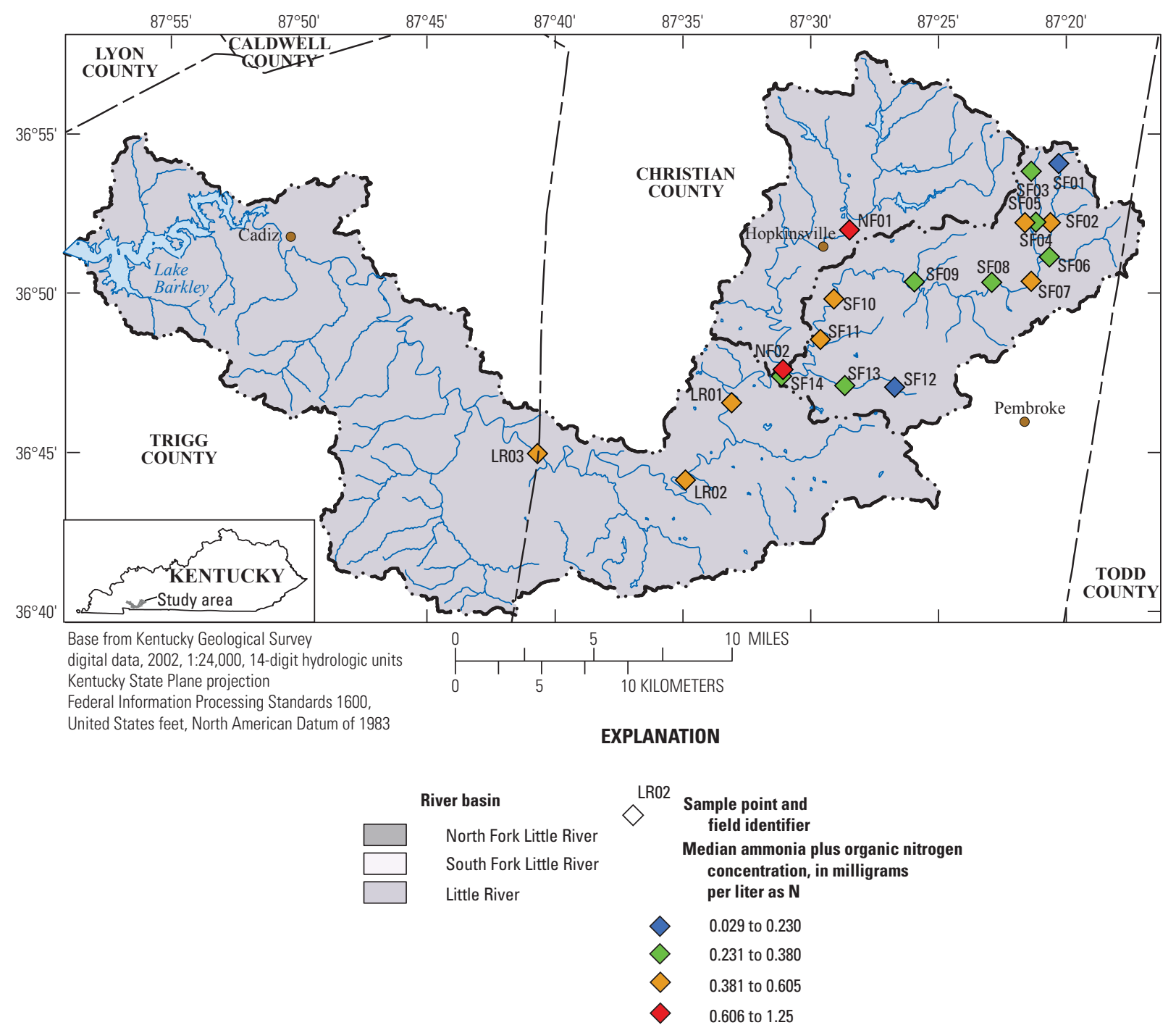

Figure 14. Median concentrations of ammonia plus organic nitrogen at the 19 sampling sites in the North Fork Little River, South Fork Little River, and Little River Basins, Kentucky, water years 2013-14.

Concentrations of orthophosphorus (orthoP) in surfacewater samples ranged from $<0.004$ to $0.549 \mathrm{mg} / \mathrm{L}$ as $\mathrm{P}$ in the SFLR Basin (table 12, fig. 16). Median concentrations of orthoP ranged from $<0.004$ to $0.049 \mathrm{mg} / \mathrm{L}$ as $\mathrm{P}$ in the SFLR Basin (fig. 18). Surface-water concentrations of orthoP in the NFLR Basin were lowest upstream at site NF01 $(<0.004 \mathrm{mg} / \mathrm{L}$ as $\mathrm{P})$ and highest $(2.33 \mathrm{mg} / \mathrm{L}$ as $\mathrm{P})$ downstream at site NF02 (table 12, fig. 16). Median concentrations of orthoP in the NFLR Basin were $0.012 \mathrm{mg} / \mathrm{L}$ as $\mathrm{P}$ at site NF01 and $0.162 \mathrm{mg} / \mathrm{L}$ as $\mathrm{P}$ at site NF02 (fig. 18). Concentrations of orthoP at the Little River sites ranged from $0.028 \mathrm{mg} / \mathrm{L}$ as $\mathrm{P}$ at site LR03 to $0.992 \mathrm{mg} / \mathrm{L}$ as $\mathrm{P}$ at site LR01. Median concentrations of orthoP at the Little River sites ranged from $0.112 \mathrm{mg} / \mathrm{L}$ as P at site $\mathrm{LR} 02$ to $0.153 \mathrm{mg} / \mathrm{L}$ as P at site LR01.

The relation between nutrient concentrations and streamflow has important implications for resource management and generally can reflect the dominant nutrient sources (point versus nonpoint sources) in a watershed. Nonpoint-source-derived nutrient constituents are transported mainly during periods of runoff; therefore, higher nutrient concentrations are expected during high streamflow in watersheds dominated by nonpoint sources. Concentrations of nutrient constituents from point sources typically decrease during high streamflow because point-source discharges generally are not associated with runoff. Observed increases in streamflow at site NF02 showed decreased concentrations of all nutrient constituents, suggesting the dominant nutrient source is possibly point-source related. Conversely, increased streamflow at site SF14 showed increased concentrations of nitrogen constituents, suggesting the dominant source of nitrogen is related to nonpoint sources. Concentrations of TP and orthoP at site SF14 were similar during low and high flows but increased during intermediate flows. 


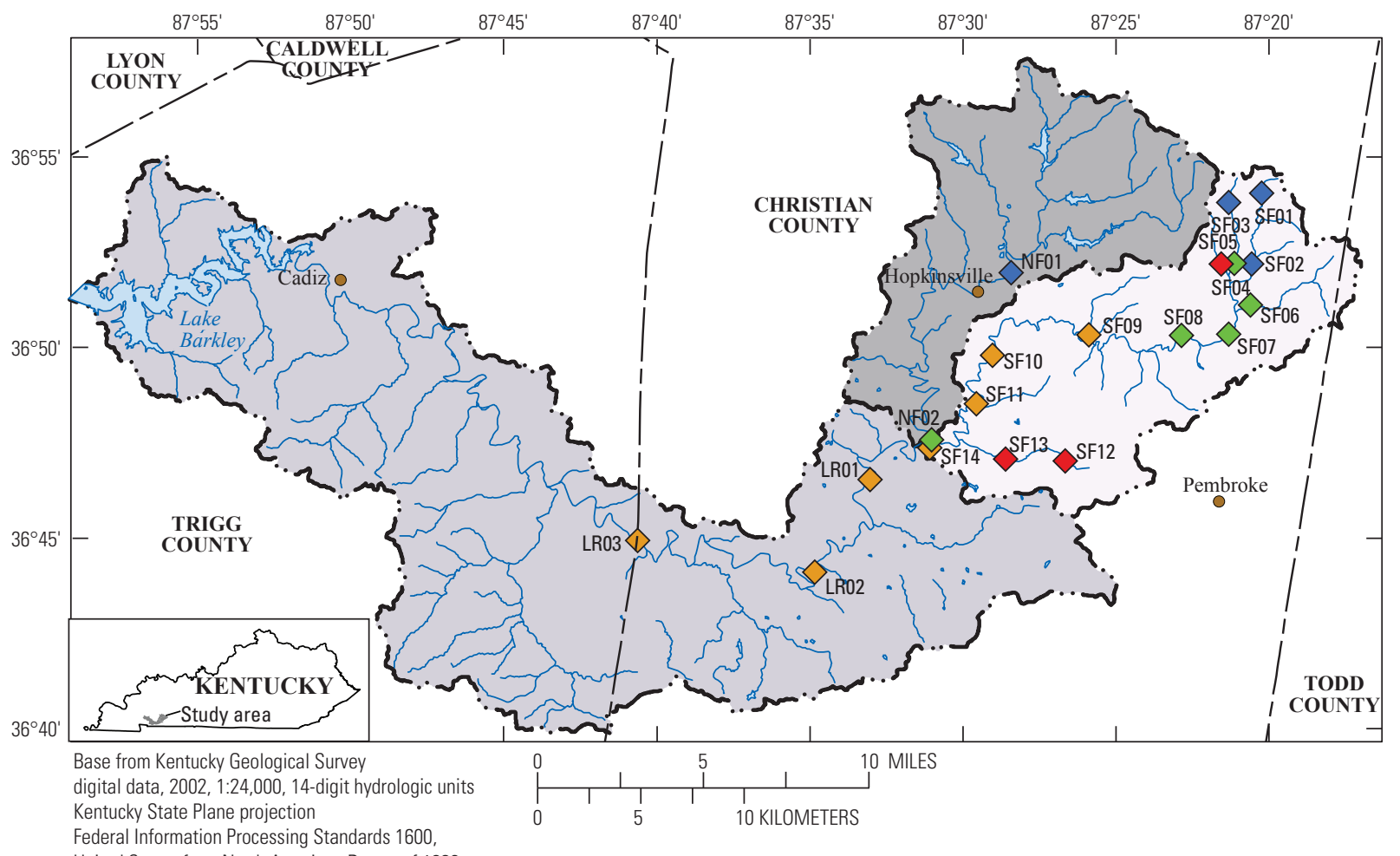

Federal Information Processing Standards 1600,

United States feet, North American Datum of 1983

\section{EXPLANATION}

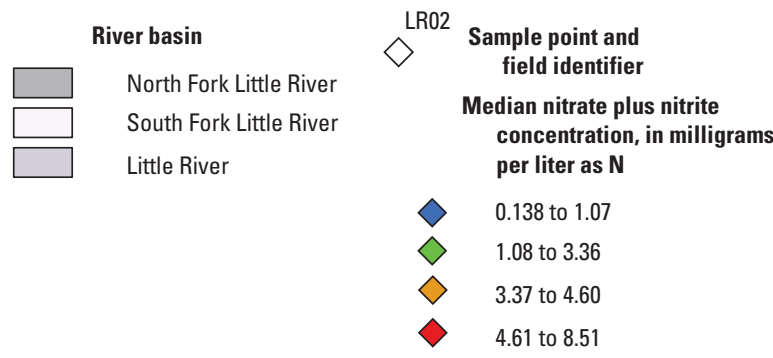

Figure 15. Median concentrations of nitrite plus nitrate $\left(\mathrm{NO}_{2}+\mathrm{NO}_{3}\right)$ at the 19 sampling sites in the North Fork Little River, South Fork Little River, and Little River Basins, Kentucky, water years 2013-14.

\section{Concentrations of Nutrients at Sites NF02, SF09, and SF14}

Nutrients of interest were evaluated on a seasonal and streamflow-related basis at sites NF02, SF09, and SF14. Sites NF02 and SF14 represent their respective basin outflows. Site SF09 was selected to represent the upper half of the SFLR Basin. By correlating streamflow and concentrations of $\mathrm{NO}_{2}+\mathrm{NO}_{3}$, sources of nitrate (nonpoint, point, or groundwater) possibly can be determined. A statistically significant positive correlation suggests nonpoint sources in surface runoff (increase in concentration as streamflow increases), whereas a statistically significant negative correlation indicates dilution and high flow and suggests groundwater or point source(s). Concentrations of $\mathrm{NO}_{2}+\mathrm{NO}_{3}$ in surface water showed limited seasonal variability at all three sites (figs. 19, 20, 21). Concentrations of $\mathrm{NO}_{2}+\mathrm{NO}_{3}$ were positively correlated to streamflow at site SF09 $($ rho $=0.42, p$-value $=0.035)$ and site SF14 $($ rho $=$ $0.68, p$-value $<0.001)$. The positive correlations observed between concentrations of $\mathrm{NO}_{2}+\mathrm{NO}_{3}$ and streamflow suggest nitrogen-enriched nonpoint source runoff during higher streamflow is a factor causing higher concentrations of $\mathrm{NO}_{2}+\mathrm{NO}_{3}$ at these sites. Nitrogen accumulation in the soils during the 2012 drought followed by the release of nitrate by rainfall in 2013 also could be a contributing factor of higher concentrations of $\mathrm{NO}_{2}+\mathrm{NO}_{3}$ in streamflow (Van Metre and others, 2016). Concentrations of $\mathrm{NO}_{2}+\mathrm{NO}_{3}$ were negatively correlated to streamflow at site NF02 $($ rho $=-0.51, p$-value $=$ 0.009). Concentrations of ammonia $\left(\mathrm{NH}_{3}+\mathrm{NH}_{4}^{+}\right)$also were negatively correlated with streamflow at the NF02 site (rho= $-0.29, p$-value $=0.023)$. These findings suggest point source $(\mathrm{s})$ at site NF02 are the most probable cause of higher concentrations of $\mathrm{NO}_{2}+\mathrm{NO}_{3}$ and $\mathrm{NH}_{3}+\mathrm{NH}_{4}^{+}$than nonpoint sources. Concentrations of $\mathrm{NH}_{3}+\mathrm{NH}_{4}^{+}$and $\mathrm{NH}_{4}^{+}+$orgN at sites $\mathrm{SF} 09$ and 


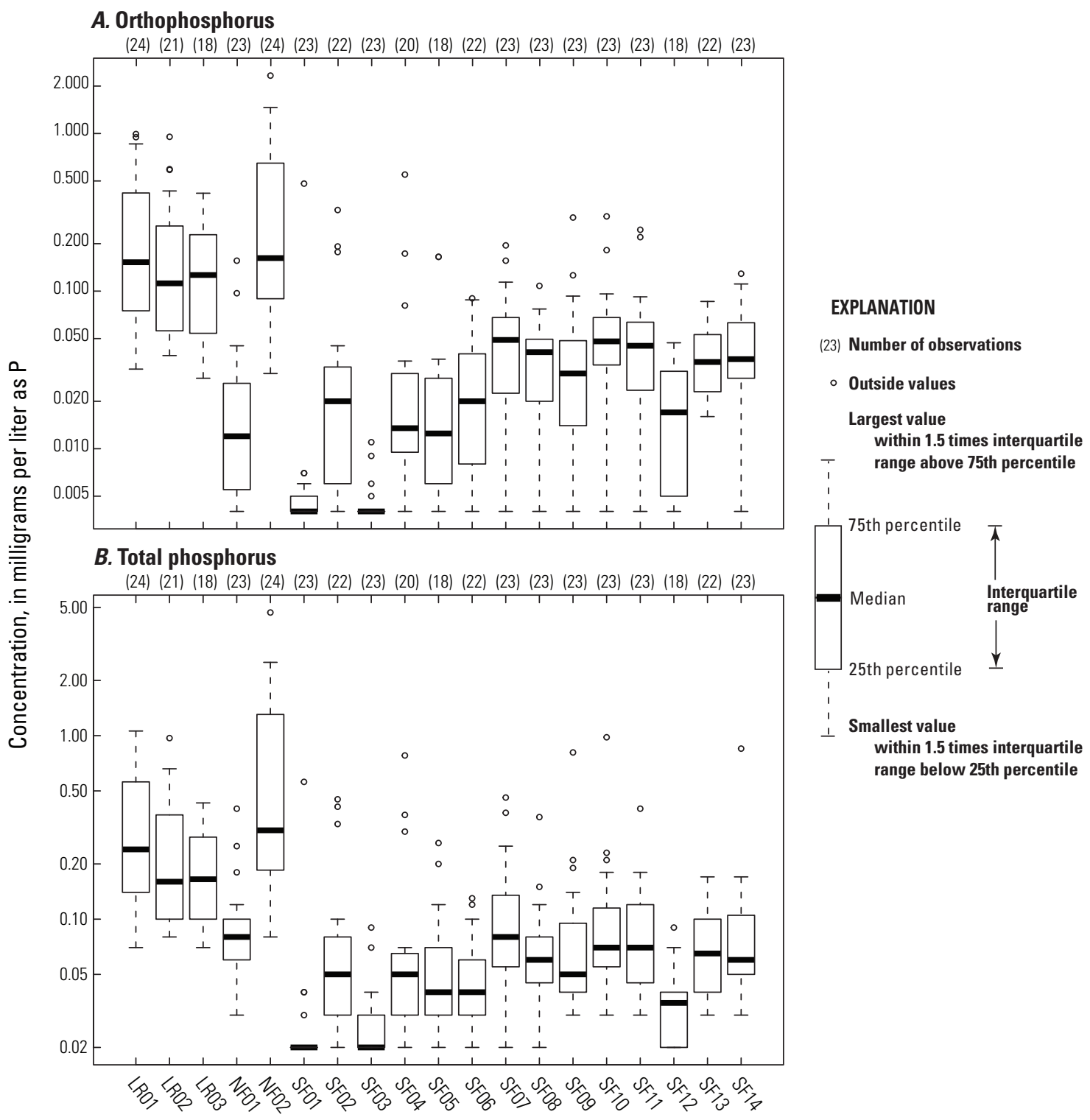

Field identification number

Figure 16. Concentrations of $A$, orthophosphorus and $B$, total phosphorus in the North Fork Little River, South Fork Little River, and Little River Basins, Kentucky, water years 2013-14.

SF14 were not statistically correlated with streamflow. Generally, $\mathrm{NH}_{4}^{+}+\operatorname{orgN}$ concentrations were lower than $\mathrm{NO}_{2}+\mathrm{NO}_{3}$ concentrations at the three sites of interest.

Concentrations of orthoP had similar seasonal variability as concentrations of TP at the three sites of interest (figs. 19, 20, 21). Concentrations of TP and orthoP were positively correlated to streamflow at site SF9 (TP: rho $=0.96, p$-value $<0.001$; orthoP: rho $=0.87, p$-value $<0.001)$ indicating erosion or transport of phosphorus at high flows was a dominant process suggesting nonpoint sources are the primary source of phosphorus. Conversely, phosphorus species were negatively correlated to streamflow at the NF02 site (TP: rho $=-0.71$, $p$-value $<0.001$; orthoP: $\mathrm{rho}=-0.87, p$-value $<0.001)$ indicating dilution was a dominant process suggesting groundwater or point sources are the primary source(s) of phosphorus. There was no statistically significant correlation between streamflow and either phosphorus species at site SF14 (TP: rho=0.30, $p$-value 0.164 ; orthoP: rho $=0.11, p$-value 0.604$)$.

\section{Estimated Loads and Yields of Select Nutrients at Sites NF02, SF09, and SF14}

Stream load is defined as the mass of a given waterborne constituent moving past a given point per unit of time and is expressed in units of pounds per year. Annual loads can vary 


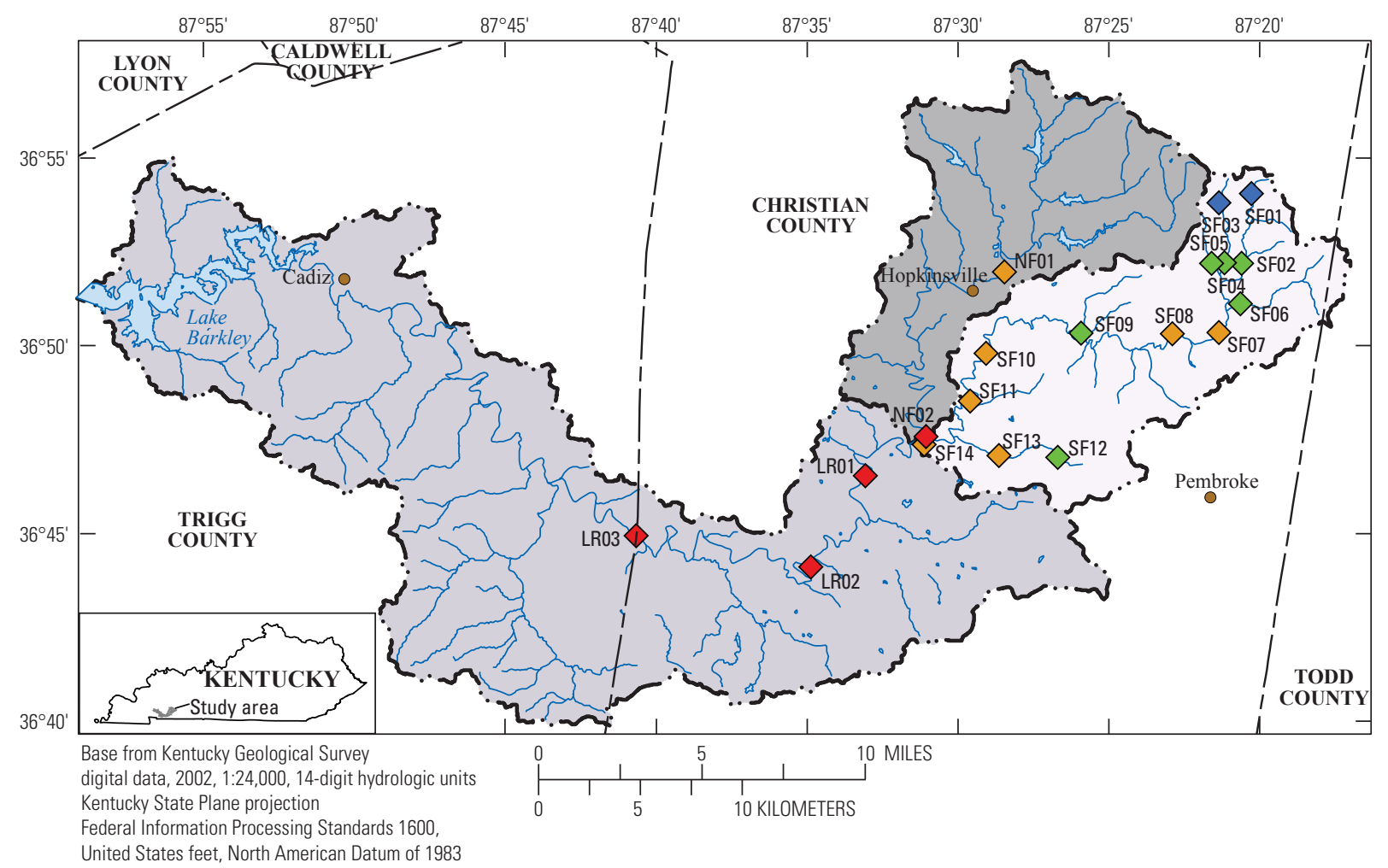

EXPLANATION
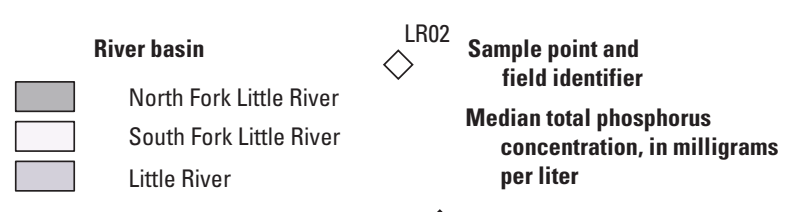

$\begin{array}{ll}\diamond & \text { Less than } 0.020 \\ \diamond & 0.021 \text { to } 0.050 \\ \diamond & 0.051 \text { to } 0.080 \\ & 0.081 \text { to } 0.305\end{array}$

Figure 17. Median concentrations of total phosphorus at the 19 sampling sites in the North Fork Little River, South Fork Little River, and Little River Basins, Kentucky, water years 2013-14.

depending on drainage basin size, hydrologic conditions, climatological conditions, weather, and land uses within a basin. Mean annual loads for nutrients were estimated using the S-LOADEST program at three sampling sites from samples collected in water years 2013-14. Loads were not estimated at the remaining 16 sampling sites because of the lack of continuous streamflow at each site or extremely small watershed size. Two of the three sampling sites were in the SFLR Basin and one sampling site was at the outlet of the NFLR Basin. The 95-percent confidence interval for each estimated annual load of TN, $\mathrm{NO}_{2}+\mathrm{NO}_{3}$, TP, and orthoP was calculated from the standard error of prediction provided by the SPlus software program (TIBCO, 2008). The confidence interval is shown in pounds per year.

The coefficients of determination $\left(\mathrm{R}^{2}\right)$ for the best-fit regression models for loads of $\mathrm{TN}, \mathrm{NH}_{4}^{+}+\operatorname{orgN}, \mathrm{NO}_{2}+\mathrm{NO}_{3}$,
$\mathrm{TP}$, and orthoP are listed in table 13 . High $\mathrm{R}^{2}$ values indicate the models for all five constituents successfully simulated the variability in constituent loads at the selected sampling sites. However, loads of TP and orthoP at the NF02 site showed moderate relations with streamflow with $\mathrm{R}^{2}$ values of 61.7 and 34.3 percent, respectively, indicating streamflow had a lesser role in the amount of loads for these constituents. Overall, the model simulations for $\mathrm{NO}_{2}+\mathrm{NO}_{3}$ showed the highest $\mathrm{R}^{2}$ values. On the basis of the $\mathrm{R}^{2}$ values, the model simulations for TP showed a better fit than the orthoP model. The better fit for TP likely is related to the suspended components of TP. Generally, suspended material has a stronger relation to streamflow than the dissolved components such as orthoP.

Load estimates using long periods of streamflow and water-quality records generally are more reliable than estimates for sites with short periods of streamflow and 


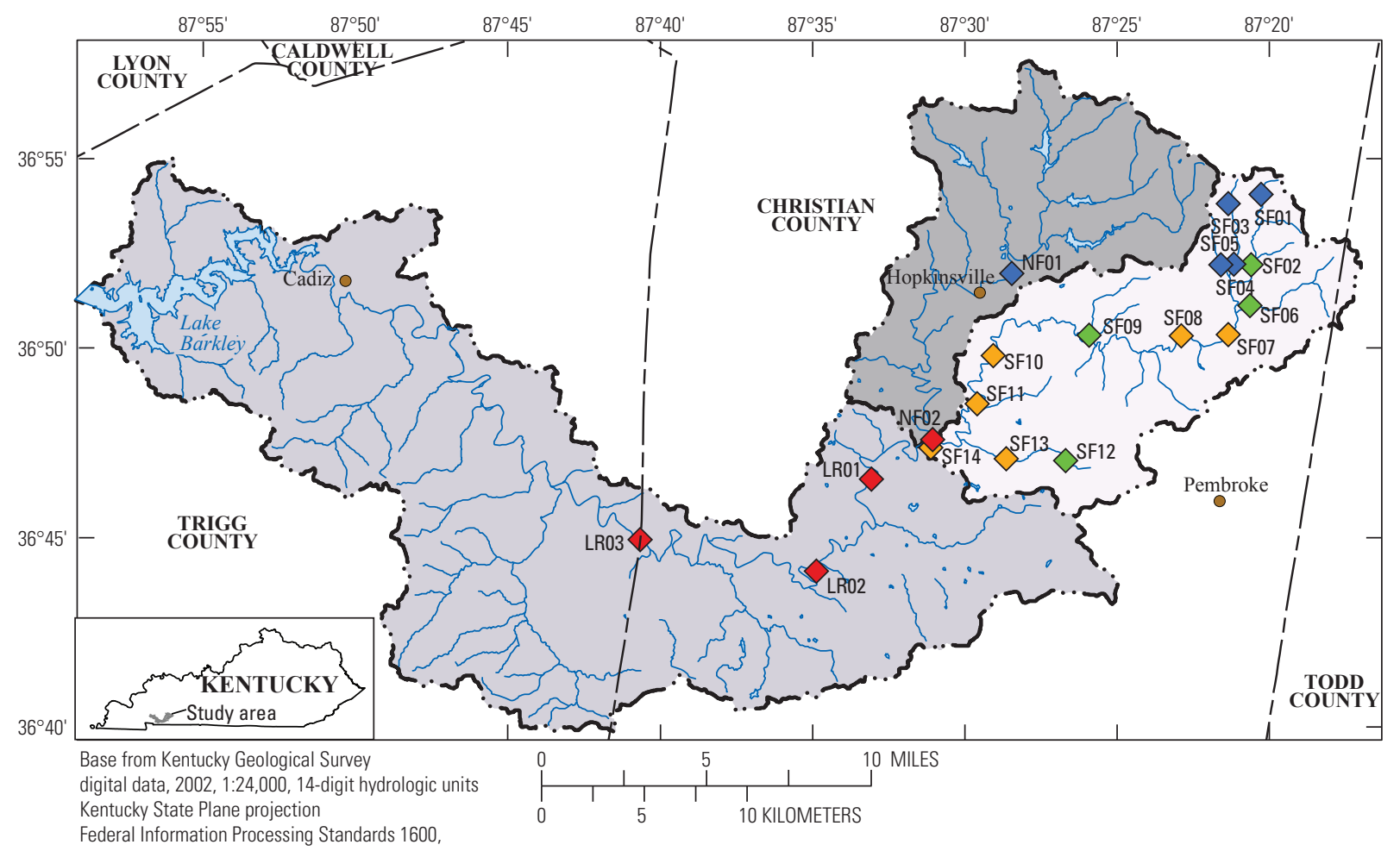

Federal Information Processing Standards 1600,

United States feet, North American Datum of 1983

EXPLANATION

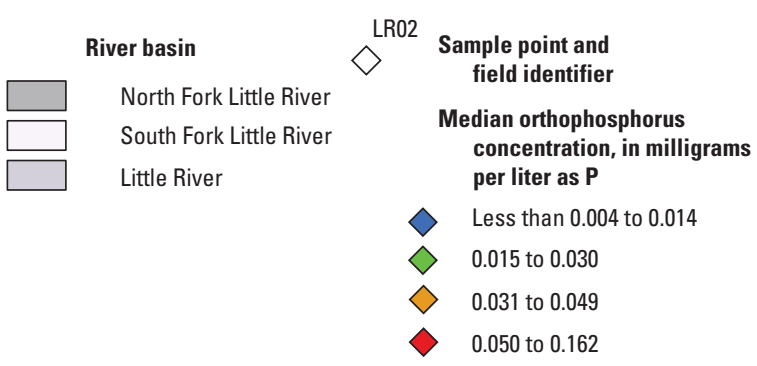

Figure 18. Median concentrations of orthophosphorus at the 19 sampling sites in the North Fork Little River, South Fork Little River, and Little River Basins, Kentucky, water years 2013-14.

water-quality records. A longer period of record provides more available data to calibrate the load-estimation model and results in a better estimate of the long-term load. Changes in streamflow are one of the primary factors affecting water quality in the SFLR and NFLR Basins. The variability in flow affects the observed concentrations and the mean nutrient and sediment load delivered to the streams. Estimated mean annual loads for this study (water years 2013-14) were compared to estimated mean annual loads from a previous study (water years 2003-4) in the Little River Basin (Crain, 2006). Overall, the mean annual streamflows were fairly similar between the SFLR and NFLR, as well as between the two studies. The SFLR mean annual streamflows for water years 2013-14 and water years 2003-4 were 113 and $107 \mathrm{ft}^{3} / \mathrm{s}$, respectively. The NFLR mean annual streamflows for water years 2013-14 and water years 2003-4 were 104 and $106 \mathrm{ft}^{3} / \mathrm{s}$, respectively.
Previous investigations were conducted to determine water quality in streams within the basin and estimate loads delivered to Lake Barkley from the Little River and its tributaries. Crain (2001) published mean annual loads of nutrients and total suspended solids from 1985-97 using water-quality data for a state ambient-monitoring network site in the Little River Basin (Little River at Cadiz, Ky.). Crain (2006) published nutrient and suspended-sediment loads from three tributaries to the Little River and the Little River itself for water years 2003-4. The tributaries included the NFLR, the SFLR, and the Sinking Fork. Estimated annual $\mathrm{NO}_{2}+\mathrm{NO}_{3}$ and TP loads equated to an estimated 31 and 20 percent, respectively, being contributed from the SFLR to the Little River. The SFLR contributed 18 percent of the estimated annual suspended-sediment load in the Little River. The NFLR Basin was estimated to contribute 18 percent of the $\mathrm{NO}_{2}+\mathrm{NO}_{3}$ load 

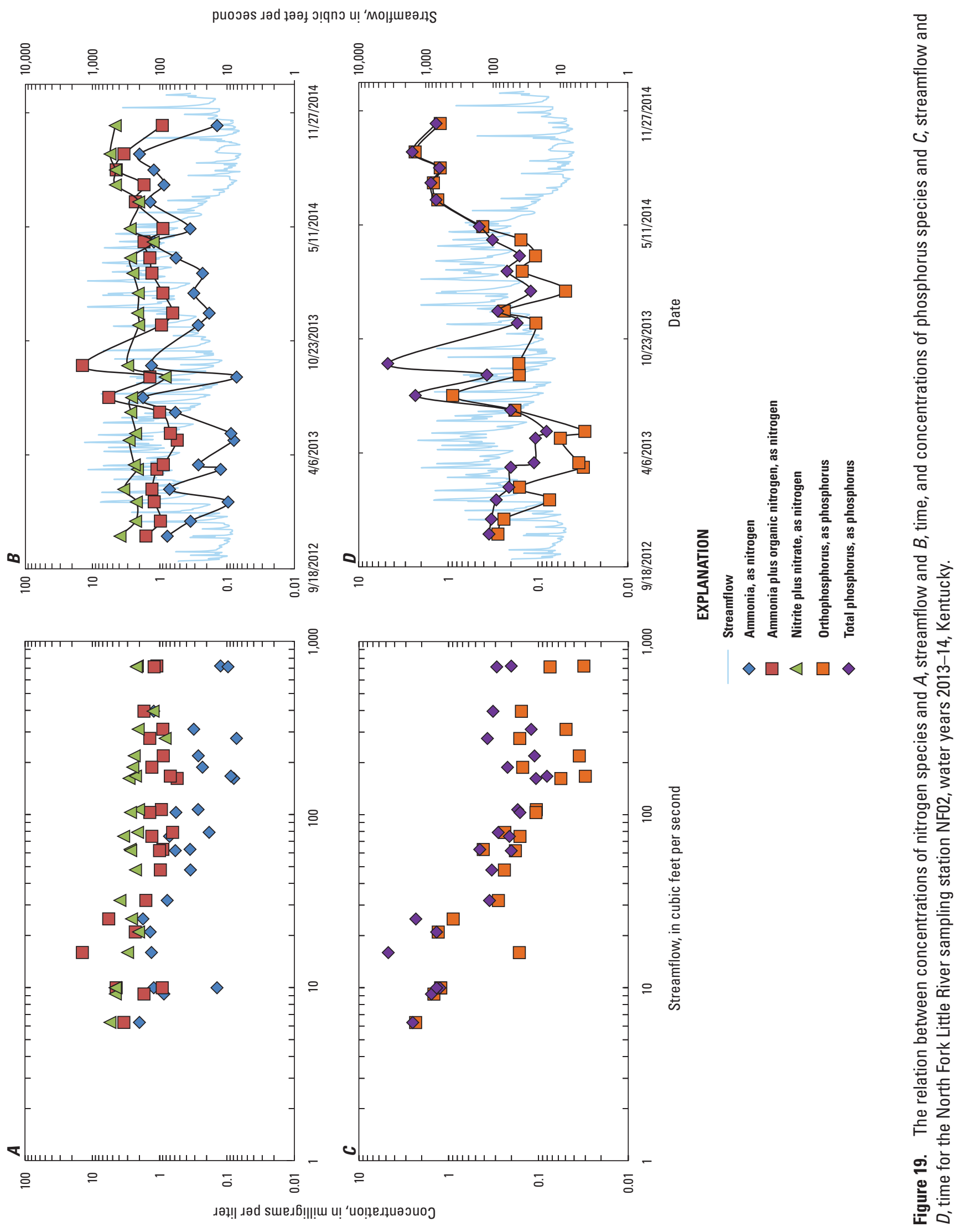


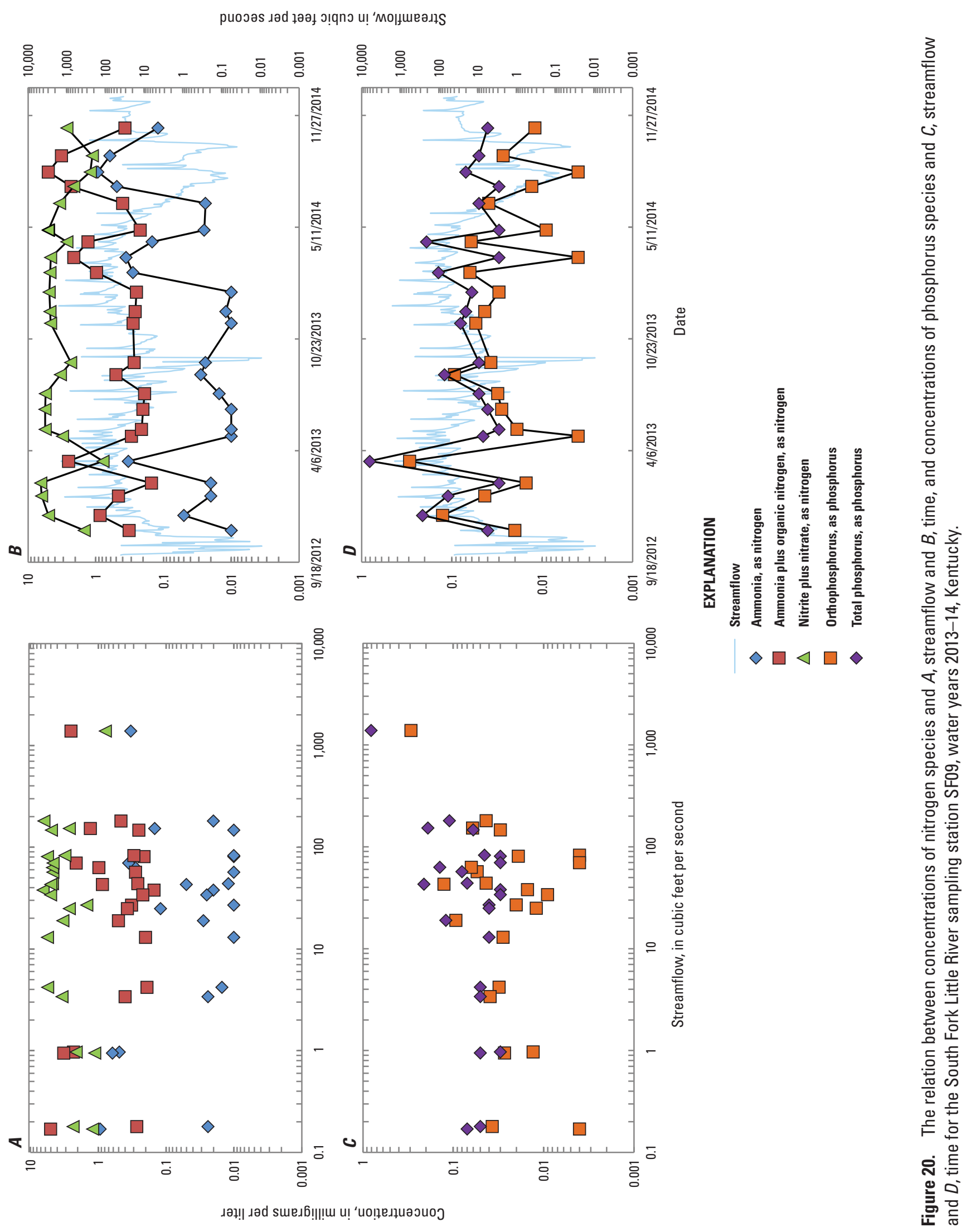




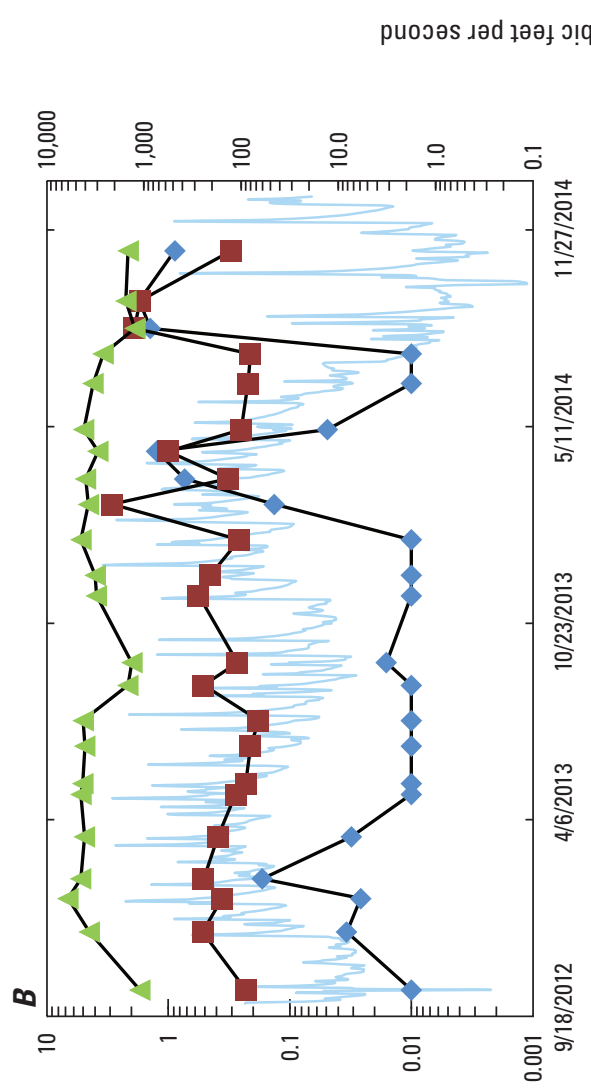

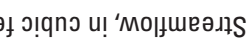

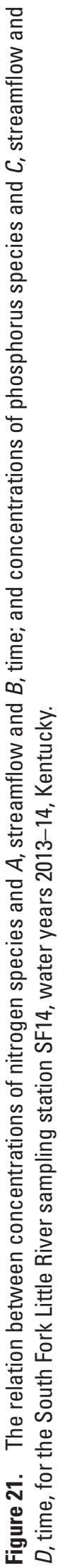


Table 13. Regression coefficients and coefficients for determination $\left(R^{2}\right)$ for load regression equations used to estimate total nitrogen, ammonia plus organic nitrogen, nitrite plus nitrate, total phosphorus, and orthophosphate at select sampling sites in the upper Little River Basin, Kentucky, 2012-14.

[a, intercept; $b$, natural logarithm of streamflow; c, natural logarithm of streamflow squared; $d$, sine; e, cosine; f, time centered in decimal years; $g$, time centered in decimal years squared]

\begin{tabular}{|c|c|c|c|c|c|c|c|c|c|}
\hline \multirow{2}{*}{$\begin{array}{c}\text { Field } \\
\text { identifier }\end{array}$} & \multirow[b]{2}{*}{ Nutrient } & \multicolumn{8}{|c|}{ Regression coefficient } \\
\hline & & a & b & c & d & $\mathbf{e}$ & $\mathbf{f}$ & g & $\begin{array}{c}R^{2} \\
\text { (percent) }\end{array}$ \\
\hline \multirow{2}{*}{ NF02 } & Ammonia plus organic nitrogen, as nitrogen & 5.60 & 0.414 & 0.259 & -0.594 & -1.670 & 0.050 & 0.015 & 84.4 \\
\hline & Nitrite plus nitrate, as nitrogen & 5.89 & 0.577 & 0.080 & 0.374 & 0.226 & -0.186 & & 97.7 \\
\hline \multirow[t]{4}{*}{ SF09 } & Total nitrogen, as nitrogen & 4.52 & 1.02 & & & & 0.068 & & 98.1 \\
\hline & Ammonia plus organic nitrogen, as nitrogen & 1.94 & 1.01 & 0.080 & & & 0.735 & & 88.5 \\
\hline & Nitrite plus nitrate, as nitrogen & 4.68 & 0.904 & -0.068 & 0.523 & 0.253 & -0.213 & & 97.8 \\
\hline & Total phosphorus, as phosphorus & -0.387 & 1.26 & 0.085 & -0.481 & -0.121 & & & 96.6 \\
\hline \multirow{3}{*}{ SF14 } & Nitrite plus nitrate, as nitrogen & 5.10 & 1.04 & -0.027 & 0.394 & 0.066 & -0.142 & & 99.0 \\
\hline & Total phosphorus, as phosphorus & 0.643 & 1.28 & 0.063 & -0.578 & -0.005 & & & 93.0 \\
\hline & Orthophosphate, as phosphorus & 0.360 & 1.17 & & -0.715 & -0.029 & -0.458 & & 91.7 \\
\hline
\end{tabular}

and 64 percent of the TP load in the Little River. Thirty-six percent of the estimated annual suspended-sediment load in the Little River was contributed by the SFLR.

The SFLR Basin contributed the largest amount of $\mathrm{TN}$ to the Little River with an estimated mean load of $1,080,000 \mathrm{lb} / \mathrm{yr}$ and yield of $16,000 \mathrm{lb} / \mathrm{yr} / \mathrm{mi}^{2}$ at site $\mathrm{SF} 14$, while the NFLR Basin contributed an estimated mean load of $730,000 \mathrm{lb} / \mathrm{yr}$ and yield of $12,600 \mathrm{lb} / \mathrm{yr} / \mathrm{mi}^{2}$ at site NF02 from November 2012 to November 2014 (table 14). Estimated mean loads of $\mathrm{NO}_{2}+\mathrm{NO}_{3}$ showed a similar pattern as TN with larger estimated mean loads and yields being contributed from the SFLR Basin $\left(840,000 \mathrm{lb} / \mathrm{yr} ; 12,500 \mathrm{lb} / \mathrm{yr} / \mathrm{mi}^{2}\right)$ than the NFLR Basin (420,000 lb/yr; 7,200 lb/yr/mi²). Crain (2006) reported similar estimated loads of $\mathrm{NO}_{2}+\mathrm{NO}_{3}$ from the SFLR and NFLR Basins as were estimated for this study (table 15). The estimated mean load of $\mathrm{NH}_{4}^{+}+$orgN contributed from the NFLR Basin $(275,000 \mathrm{lb} / \mathrm{yr})$ was 58 percent larger than the estimated mean load of $\mathrm{NH}_{4}^{+}+$orgN contributed from the SFLR Basin (174,000 lb/yr).

The NFLR Basin (site NF02) contributed the greatest amount of TP and orthoP to the Little River; the estimated mean loads of TP and orthoP were $63,000 \mathrm{lb} / \mathrm{yr}$ and 34,000 lb/yr from November 2012 to November 2014, respectively (table 14). In 2003-04, the NFLR Basin contributed 52 percent more mean loads of TP and 118 percent more mean loads of orthoP than in 2013-14 (table 15). Estimated yields of TP and orthoP from the NFLR Basin were 1,100 and $590 \mathrm{lb} / \mathrm{yr} / \mathrm{mi}^{2}$, respectively. The estimated mean loads of TP and orthoP contributed from the SFLR Basin (site SF14) were 36,500 and $8,000 \mathrm{lb} / \mathrm{yr}$, respectively (table 14). Crain (2006) reported similar estimated mean loads of TP from the SFLR Basin, but estimated mean loads of orthoP were 75 percent larger in 2003-4 than in 2013-14 (table 15). Estimated yields of TP and orthoP from the SFLR Basin were 540 and $120 \mathrm{lb} / \mathrm{yr} / \mathrm{mi}^{2}$, respectively.

\section{Results of Dual-Nitrate Isotopes}

Dual-nitrate isotopes $\left(\delta^{15} \mathrm{~N}_{\mathrm{NO} 3}\right.$ and $\left.\delta^{18} \mathrm{O}_{\mathrm{NO} 3}\right)$ are useful in differentiating inorganic sources (atmospheric and synthetic fertilizer) from organic sources (manure and septic waste). Knowledge of the primary nitrogen sources in the SFLR Basin is important for resource managers in making informed decisions regarding implementation of conservation and watershed-management activities. Dual-nitrate isotopes in combination with nitrate concentrations in surface water have been used as tracers for identifying sources of nitrate among different land uses (Cravotta, 1997; Kellman and HillaireMarcel, 2003; Kendall and others, 2007; Burns and others, 2009; Xue and others, 2009; Kaushal and others, 2011). Typical source values of $\delta^{15} \mathrm{~N}_{\mathrm{NO} 3}$ and $\delta^{18} \mathrm{O}_{\mathrm{NO} 3}$ used to interpret the dual-isotope data in this report are summarized in figure 22 . 
Table 14. Summary of select nutrient loads and yields at select sites in the upper Little River Basin, Kentucky, 2013-14.

[*, November 2012 to November 2014; lb/yr, pound per year; lb/yr/mi², pound per year per square mile]

\begin{tabular}{|c|c|c|c|c|c|}
\hline Nutrient & $\begin{array}{c}\text { Mean load } \\
2013-2014 \\
(\mathrm{lb} / \mathrm{yr})^{*}\end{array}$ & Lower* & Upper* & $\begin{array}{l}\text { Standard error } \\
\text { of prediction }\end{array}$ & $\begin{array}{c}\text { Mean yield } \\
2013-2014 \\
\left(\mathrm{lb} / \mathrm{yr} / \mathrm{mi}^{2}\right)^{*}\end{array}$ \\
\hline \multicolumn{6}{|c|}{ North Fork Little River at Gary Lane near Hopkinsville, KY (site NF02) (Drainage area = $58.1 \mathrm{mi}^{2}$ ) } \\
\hline Total nitrogen, as nitrogen & 730,000 & 622,000 & 845,000 & 56,800 & 12,600 \\
\hline Ammonia plus organic nitrogen, as nitrogen & 275,000 & 187,000 & 390,000 & 52,000 & 4,700 \\
\hline Orthophosphate, as phosphorus & 34,000 & 25,000 & 45,300 & 5,100 & 585 \\
\hline \multicolumn{6}{|c|}{ South Fork Little River at US 69-8 bypass at Hopkinsville, KY (site SF09) (Drainage area $=35.9 \mathrm{mi}^{2}$ ) } \\
\hline Total nitrogen, as nitrogen & 560,000 & 450,000 & 687,000 & 60,600 & 15,600 \\
\hline Ammonia plus organic nitrogen, as nitrogen & 129,000 & 40,500 & 312,000 & 71,900 & 3,600 \\
\hline \multicolumn{6}{|c|}{ South Fork Little River at KY 107 near Hopkinsville, KY (site SF14) (Drainage area = $67.4 \mathrm{mi}^{2}$ ) } \\
\hline Total nitrogen, as nitrogen & $1,080,000$ & 930,000 & $1,250,000$ & 80,700 & 16,000 \\
\hline Ammonia plus organic nitrogen, as nitrogen & 174,000 & 5,100 & 980,000 & 140,000 & 2,600 \\
\hline Nitrite plus nitrate, as nitrogen & 840,000 & 676,000 & $1,025,000$ & 89,000 & 12,500 \\
\hline Total phosphorus, as phosphorus & 36,500 & 3,800 & 146,000 & 42,700 & 540 \\
\hline Orthophosphate, as phosphorus & 8,000 & 3,200 & 16,400 & 3,400 & 120 \\
\hline
\end{tabular}

Table 15. Summary of select nutrient loads and yields, 2003-4 and 2013-14.

[*, November 2012 to November 2014; lb/yr, pound per year; lb/yr/mi², pound per year per square mile]

\begin{tabular}{|c|c|c|c|c|}
\hline Nutrient & $\begin{array}{c}\text { Mean annual load } \\
\text { 2003-2004 } \\
\text { (lb/yr) }\end{array}$ & $\begin{array}{c}\text { Mean load } \\
2013-2014 \\
(\mathrm{lb} / \mathrm{yr})^{*}\end{array}$ & $\begin{array}{c}\text { Mean annual yield } \\
2003-2004 \\
\left(\mathrm{lb} / \mathrm{yr} / \mathrm{mi}^{2}\right)\end{array}$ & $\begin{array}{c}\text { Mean yield } \\
2013-2014 \\
\left(\mathrm{lb} / \mathrm{yr} / \mathrm{mi}^{2}\right)^{*}\end{array}$ \\
\hline \multicolumn{5}{|c|}{ North Fork Little River at Gary Lane near Hopkinsville, KY (site NF02) (drainage area = $58.1 \mathrm{mi}^{2}$ ) } \\
\hline Nitrite plus nitrate, as nitrogen & 450,000 & 420,000 & 7,800 & 7,200 \\
\hline Total phosphorus, as phosphorus & 107,000 & 63,000 & 1,800 & 1,100 \\
\hline Orthophosphate, as phosphorus & 74,000 & 34,000 & 1,300 & 590 \\
\hline \multicolumn{5}{|c|}{ South Fork Little River at KY 107 near Hopkinsville, KY (site SF14) (drainage area = $67.4 \mathrm{mi}^{2}$ ) } \\
\hline Nitrite plus nitrate, as nitrogen & 780,000 & 840,000 & 11,600 & 12,500 \\
\hline Total phosphorus, as phosphorus & 32,000 & 36,500 & 480 & 540 \\
\hline Orthophosphate, as phosphorus & 14,000 & 8,000 & 210 & 120 \\
\hline
\end{tabular}




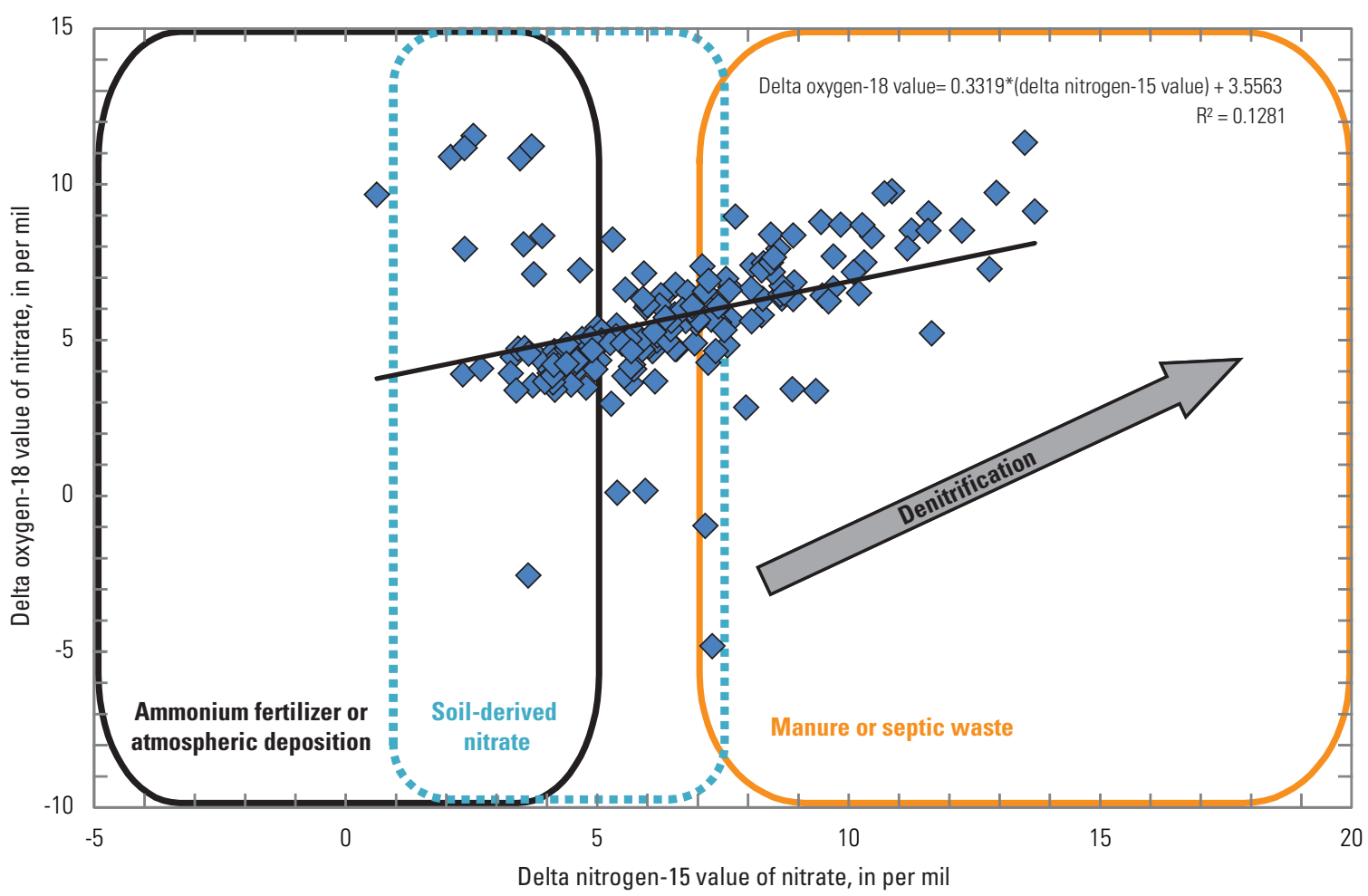

Figure 22. Relation between delta oxygen-18 and delta nitrogen-15 values with literature values of potential nitrate sources, from surface-water samples collected from the South Fork Little River Basin, Kentucky, water years 2013-14. (Modified from Kendall and others, 2007; Xue and others, 2009)

The range of source values of $\delta^{15} \mathrm{~N}_{\mathrm{NO} 3}$ and $\delta^{18} \mathrm{O}_{\mathrm{NO} 3}$ as shown in figure 22 are not absolute, because the different dual-nitrate value ranges correspond to source types that exist in scientific literature (Böhlke and others, 2003; Kendall and others, 2007; Xue and others, 2009).

The dual-nitrate isotope technique is a powerful tool in identifying sources of nitrate; however, there are limitations because of the isotopic variability and mixing of nitrate sources and the fractionation process that takes place during denitrification (the reduction of nitrate to nitrogen gas) (Panno and others, 2006; Ding and others, 2014). Additionally, it should be noted that the dual-isotope approach is not suitable for discriminating between manure and septic waste. However, for this study, MST techniques were explored to distinguish between human and animal waste in streams. These results can be found in Part 2 of this report-"Microbiological WaterQuality and Source Assessment."

Nitrogen sources indicated by dual-nitrate isotope samples collected in the SFLR and NFLR Basins are evaluated in terms of land-use and seasonal variability. Various isotope standards are used for reporting isotopic compositions; however, a positive delta $(\delta)$ value means the sample contains more of the heavy isotope than the standard, and a negative delta $(\delta)$ value means the sample contains less of the heavy isotope than the standard (Kendall,1998).

\section{South Fork Little River Basin}

A total of 175 dual-nitrate isotopes samples were collected at 11 sampling sites within the SFLR Basin (table 1). Six sampling sites (SF01, SF02, SF07, SF09, SF10, and SF14) were selected along the main stem of the SFLR (table 1). Additional sampling sites on select tributaries to the SFLR include two sites along an unnamed tributary (sites SF03 and SF05), one site on Warrens Fork (site SF06), and two sites along Rock Bridge Branch (sites SF12 and SF13). Site selection was based on land-use type, availability of historical water-quality and streamflow data, areas of expected sources, and the confluence of tributaries.

Typical ranges of $\delta^{15} \mathrm{~N}_{\mathrm{NO} 3}$ and $\delta^{18} \mathrm{O}_{\mathrm{NO} 3}$ values of nitrate sources reported in literature are shown in figure 22 (Böhlke and others, 2003; Kendall and others, 2007; Xue and others, 2009). Potential nitrate sources in the SFLR Basin include atmospheric deposition, chemical fertilizer, soil-derived nitrate, manure, and septic waste. Most chemical fertilizer applied in the basin is in the form of anhydrous ammonia and urea that can subsequently oxidize to nitrate. Widely accepted $\delta^{15} \mathrm{~N}_{\mathrm{NO} 3}$ values range between -5.00 and $+5.00 \%$ for chemical fertilizers, between +2.00 and $+7.00 \%$ for soil-derived nitrate, and between +7.00 and $+20.0 \%$ for manure and septic waste (Fogg and others, 1998; Bateman and Kelly, 2007; Xue and 
others, 2009). Many data points in this study plotted within the overlapping fields of the previously mentioned potential nitrate sources in the basin (fig. 22). Values of $\delta^{15} \mathrm{~N}_{\mathrm{NO} 3}$ in the SFLR and its tributaries ranged from +0.62 to $+13.7 \%$; the median was $+6.19 \%$ (fig. 22 ). The $\delta^{18} \mathrm{O}_{\mathrm{NO} 3}$ values in these samples ranged from -4.83 to $+11.5 \%$; the median was $+5.46 \%$ (fig. 22). A weak positive linear relation $\left(\mathrm{R}^{2}=0.12\right.$; $p$-value $<0.001$ ) was shown between values of $\delta^{15} \mathrm{~N}_{\mathrm{NO3}}$ and $\delta^{18} \mathrm{O}_{\mathrm{NO} 3}$ (slope $=0.39$ ), which may suggest partial denitrified nitrate. A slope of 0.5 between values of $\delta^{15} \mathrm{~N}_{\mathrm{NO} 3}$ and $\delta^{18} \mathrm{O}_{\mathrm{NO} 3}$ in groundwater has been reported to indicate the denitrification process (Böttcher and others, 1990; Burns and others, 2009). Overlapping fields of the different sources can make interpretation of nitrate isotopes challenging because biogeochemical processes control nitrogen dynamics (Panno and others, 2006), which can potentially mask the original nitrate source (Kendall and others, 2007). However, uncertainty can be reduced by considering the contributions of different sources, the variability of values in $\delta^{15} \mathrm{~N}_{\mathrm{NO} 3}$ and $\delta^{18} \mathrm{O}_{\mathrm{NO} 3}$, and the hydrology of the basin (Panno and others, 2006). No data plotted within the typical range of $\delta^{18} \mathrm{O}_{\mathrm{NO} 3}$ values for atmospheric nitrate (greater than $+60 \%$ ), indicating the atmosphere is not a dominant source of nitrogen in the sampled streams. The lack of a measurable atmospheric nitrate source has also been observed in other rivers (Mayer and others, 2002; Panno and others, 2006).

Land use commonly reflects the variations in nitrogen sources (Silva and others, 2002). In forested areas, typical nitrate sources are atmospheric deposition and soil-derived nitrate. The ranges of $\delta^{15} \mathrm{~N}_{\mathrm{NO} 3}$ values for both sources are similar; however, $\delta^{18} \mathrm{O}_{\mathrm{NO} 3}$ values can be used to distinguish the nitrate sources, because atmospheric deposition is highly enriched in ${ }^{18} \mathrm{O}$. Typical $\delta^{15} \mathrm{~N}_{\mathrm{NO} 3}$ values have been reported in other studies ranging from -1 to $+5.5 \%$ in predominantly forested areas near the outlets (Mayer and others, 2002; Nestler and others, 2011). The values of $\delta^{18} \mathrm{O}_{\mathrm{NO} 3}$ from forested sites ranged from -2.62 to $+11.6 \%$, median of $+5.60 \%$, and were more variable than the values of $\delta^{15} \mathrm{~N}_{\mathrm{NO} 3}$ (fig. 23A). Forested sites in the SFLR Basin are characteristic of soilderived nitrate with possible but minimal influence from the atmosphere.

Results from this study showed the predominantly forested sites had consistently low concentrations of nitrate with minimal variability (fig. $23 B$ ). The forested sites had the lowest median nitrate concentrations among the land uses. The concentrations of nitrate ranged from 0.080 to $2.92 \mathrm{mg} / \mathrm{L}$, and the median was $0.233 \mathrm{mg} / \mathrm{L}$. Values of $\delta^{15} \mathrm{~N}_{\mathrm{NO} 3}$ ranged from +0.62 to $+8.07 \%$; the median was $+4.66 \%$. An inverse relation was observed between nitrate concentrations and $\delta^{15} \mathrm{~N}_{\mathrm{NO} 3}$ values (fig. $\left.23 B\right)\left(\mathrm{R}^{2}=0.13\right.$; $p$-value $\left.=0.070\right)$, although the relation was not statistically significant.

Sites with mixed and agricultural land use had higher concentrations of nitrate and values of $\delta^{15} \mathrm{~N}_{\mathrm{NO} 3}$ than the forested areas. However, streams draining predominantly agricultural areas had the highest nitrate concentrations, showed the greatest variability in concentrations among the land uses (fig. $23 B$ ). Agricultural sites also had $\delta^{15} \mathrm{~N}_{\mathrm{NO} 3}$ values that were variable and generally lower than those of the mixed landuse sites; however, $\delta^{18} \mathrm{O}_{\mathrm{NO} 3}$ values were similar between the two land uses (fig. 23A). Concentrations of nitrate at agricultural sites ranged from 0.08 to $16.9 \mathrm{mg} / \mathrm{L}$ with a median of $7.55 \mathrm{mg} / \mathrm{L}$, values of $\delta^{15} \mathrm{~N}_{\mathrm{NO} 3}$ ranged from +2.09 to $+13.5 \%$ with a median of $+6.23 \%$, and values of $\delta^{18} \mathrm{O}_{\mathrm{NO} 3}$ ranged from -3.40 to $+11.33 \%$ with a median of $+5.61 \%$. Collectively, there was an inverse relation between nitrate concentrations and $\delta^{15} \mathrm{~N}_{\mathrm{NO} 3}$ values $\left(\mathrm{R}^{2}=0.16\right.$; $p$-value $\left.=0.001\right)$; as nitrate concentrations increased, $\delta^{15} \mathrm{~N}_{\mathrm{NO} 3}$ values decreased. Dual-isotope data from agricultural sites plotted within dual-nitrate isotopes ranges characteristic of possible mixtures of chemical fertilizer, soil-derived nitrate, and manure/septic wastes.

The mixed land-use values of $\delta^{15} \mathrm{~N}_{\mathrm{NO} 3}$ ranged from +2.54 to $+13.7 \%$ with a median of $+6.55 \%$, and values of $\delta^{18} \mathrm{O}$ ${ }_{\mathrm{NO} 3}$ ranged from -4.83 to $11.55 \%$ with a median of $+5.27 \%$. Concentrations of nitrate ranged from 0.06 to $8.92 \mathrm{mg} / \mathrm{L}$ with a median of $2.66 \mathrm{mg} / \mathrm{L}$. Mixed land-use sites showed an inverse relation between nitrate concentrations and $\delta^{15} \mathrm{~N}_{\mathrm{NO} 3}$ values $\left(\mathrm{R}^{2}=0.24 ; p\right.$-value $\left.<0.001\right)$. In general, mixed land-use sites exported less nitrate than agricultural sites, but dual-isotope data from mixed land-use sites also plotted within similar agricultural site ranges that are characteristic of possible mixtures of chemical fertilizer, soil-derived nitrate, and manure and septic wastes.

\section{North Fork Little River Basin}

A total of 18 dual-nitrate isotopes samples were collected at site NF02 within the NFLR Basin. Measured $\delta^{15} \mathrm{~N}_{\mathrm{NO} 3}$ and $\delta^{18} \mathrm{O}_{\mathrm{NO} 3}$ values in these samples ranged from +3.38 to $+16.4 \%$ and +2.76 to $+6.60 \%$, respectively (fig. $24 A$ ). A comparison of the values of $\delta^{15} \mathrm{~N}_{\mathrm{NO} 3}$ and $\delta^{18} \mathrm{O}_{\mathrm{NO} 3}$ in the NFLR Basin showed no statistically significant linear relation $\left(\mathrm{R}^{2}=0.03\right.$; $p$-value $=0.228$ ). Concentrations of nitrate ranged from 0.83 to $5.47 \mathrm{mg} / \mathrm{L}$ (fig. 24B). A positive linear relation was observed between nitrate concentrations and $\delta^{15} \mathrm{~N}_{\mathrm{NO} 3}$ values $\left(\mathrm{R}^{2}=0.56\right.$; $p$-value $<0.001)$. This relation potentially suggests the NFLR has a higher proportion of $\delta^{15} \mathrm{~N}_{\mathrm{NO}}$ enriched sources, such as manure and sewage. High nitrate concentrations typically have $\delta^{15} \mathrm{~N}_{\mathrm{NO} 3}$ values above $+7 \%$, which is commonly attributed to manure or sewage sources (Fogg and others, 1998). However, mixing of other nitrate-derived sources cannot be excluded because many values of $\delta^{15} \mathrm{~N}_{\mathrm{NO} 3}$ and concentrations of nitrate showed minimal variation and plotted within dual-nitrate isotopes ranges characteristic of fertilizer and soil-derived nitrate sources. 

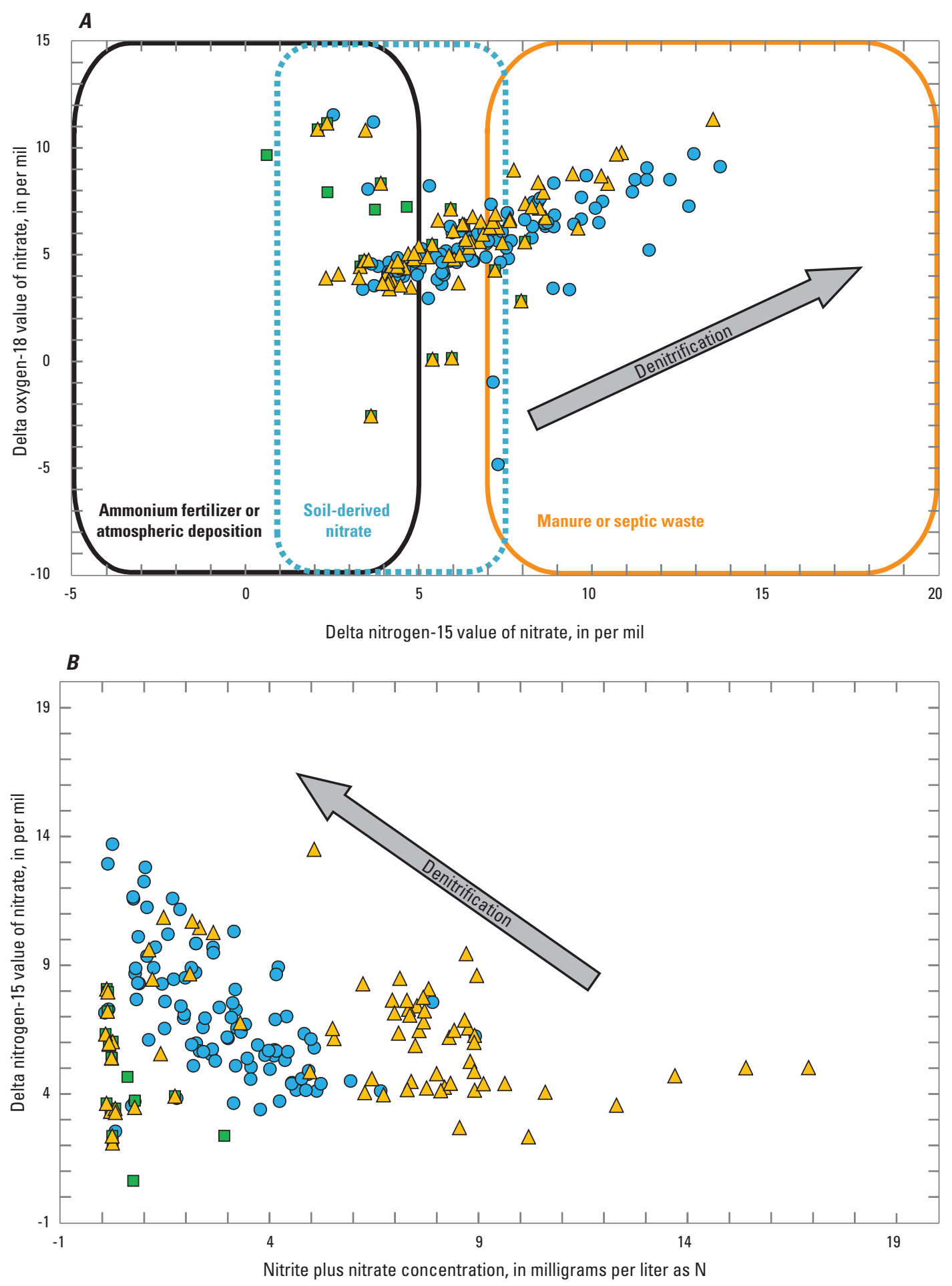

EXPLANATION

Dominant land use

$\bigcirc$ Mixed $\square$ Forest $\triangle$ Agriculture

Figure 23. Relation between $A$, delta oxygen-18 and delta nitrogen-15 values with literature values of potential nitrate sources; and $B$, delta nitrogen-15 values and nitrate concentrations, from surface-water samples collected from the South Fork Little River Basin, Kentucky, water years 2013-14. (Modified from Kendall and others, 2007; Xue and others, 2009) 

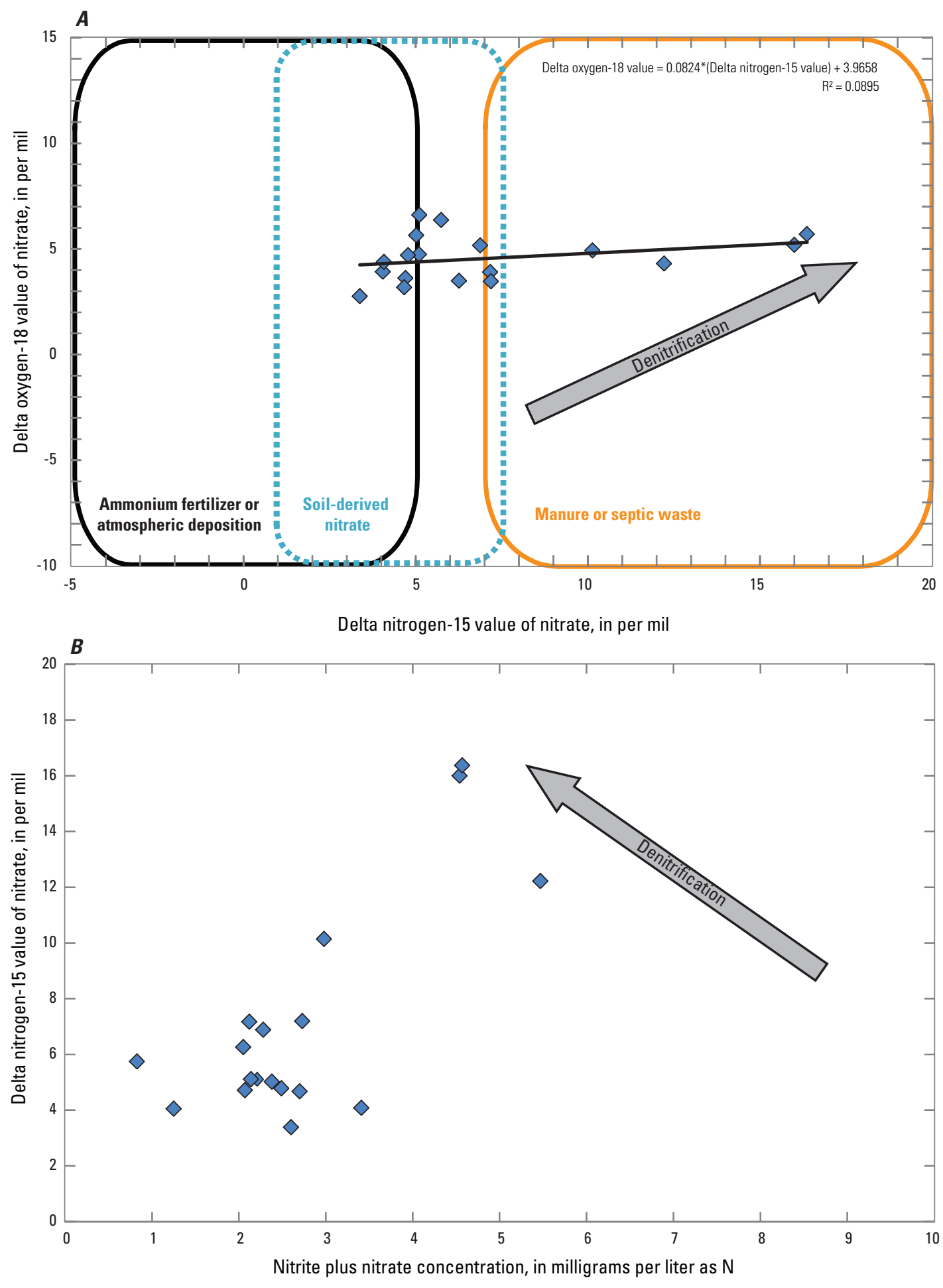

Figure 24. Relations between $A$, delta oxygen-18 and delta nitrogen-15 values with literature values of potential nitrate sources; and $B$, delta nitrogen- 15 and nitrate concentrations, from surface-water samples collected from the North Fork Little River Basin, Kentucky. (Modified from Kendall and others, 2007; Xue and others, 2009) 


\section{Part 4-Suspended-Sediment Source Assessment Using Sediment Fingerprinting}

\author{
Lead Author: Tanja N. Williamson
}

The sediment-fingerprinting approach provides a method for quantifying the proportional contribution of basin sources of fine-grained suspended sediment (Collins and others, 1997; Gellis and others, 2009; Motha and others, 2003; Walling, 2005). This approach discriminates potential sources as a function of tracers (physical/chemical properties) that uniquely characterize potential major suspended-sediment sources in the basin. Successful use of this type of sediment fingerprinting has included a variety of techniques including trace elements (Devereux and others, 2010; Gellis and Noe, 2013; Williamson and others, 2014), stable isotope ratios of carbon and nitrogen isotopes (Papanicolaou and others, 2003), and, more recently, account for the dependence of tracer concentration on particle-size distribution and organic-matter content (Gellis and Noe, 2013). Most studies have focused on sediment contributed from upland sources, including agricultural and forested lands; most studies have identified streambanks as a dominant sediment source (Mukundan and others, 2012; Nagle and others, 2007). Land recently retired from agricultural production has also been successfully discriminated in order to document how this conservation alters the sediment contribution (Williamson and others, 2014). Our objective was to quantify the relative contribution of four upland sources in the upper Little River Basin (cropland, pasture, riparian/forest, and streambank) in order to understand how land use affects suspended-sediment concentration.

\section{Collection and Laboratory Analysis of Sediment- Source and Fluvial-Target Sediment Samples}

Fifty-five (55) sediment-source samples were collected from upland-source areas and streambanks throughout the SFLR Basin in 2014. Potential upland sources in the basin were identified as cropland ( $n=13$ sites), pasture ( $n=13$ sites), and riparian/forest ( $n=15$ sites). Although rotation of fields between cropland and pasture does take place within the basin (Wayne Hunt, August 2014, oral commun.), a decision was made to keep them as separate upland source areas. Because soil types and land uses are similar to those in the SFLR Basin, samples from upland-source areas collected in the SFLR Basin were applied in the analysis for sites NF02 and LR01.

Cropland and pasture sample sites were selected on the basis of current land use in the basin and access to the site. Tillage practices at the sample sites included no-till and conventional till. To account for variability in tracer properties, a composite of 15 top-soil samples from a depth of $1 \mathrm{in}$. was collected inside a 15 -m grid at each site by using clean, nonmetal sampling equipment.

Representative streambank samples $(n=14)$ were collected from exposed streambanks by vertically scraping the bank face from top to bottom. Three to five samples were collected about every $10 \mathrm{ft}$ along the stream reach and composited into one sample. Streambanks were defined as areas adjacent to the stream in the bank-full channelized portion of the stream that contains flow.

To determine the relative contribution of suspendedsediment sources leaving the SFLR Basin, sites for potential fluvial-target sediment sampling were selected throughout the basin. Sites representative of the upland sediment sources (cropland, pasture, riparian/forest) and streambank were selected on each of two major tributaries in the SFLR Basin and three locations along the main stem including the outlet to obtain a spatially representative dataset. Fluvial-target sediment sites also were located at the NFLR outlet site and at the Little River main-stem site below the confluence of the SFLR and NFLR. Fluvial-target sediment samples were collected using a nonmetal passive sampler that was based on the design described by Phillips and others (2000). During low streamflow, each passive sampler was placed near the center of the stream channel at a depth estimated to be six tenths of the depth of observed high flow; this sampler then becomes submerged during high-flow conditions. Placement of the passive samplers in the stream channel was determined on the basis of historical streamflow data and best professional judgement. Contents of the samplers were emptied into a 3-L clean, plastic container and processed at the USGS Kentucky Sediment Laboratory. Sediment was collected at sites SF01, SF02, and SF09 after the sampling period of May 2013 to January 2014. The SF09 site had samples retrieved after the sampling period of March 2014 to October 2014. Samples were retrieved at SF14 after the sampling period of May 2013 to June 2014 and then again during the sampling period of July 2014 to October 2014. After the sampling period of May 2013 to October 2014, samples were retrieved at sites SF13, NF02, and LR01. Samples were aggregated over multiple months to ensure sufficient sediment mass was collected for analysis.

Two separate representative sample aliquots were collected from each fluvial-target sediment sample - one sample was used for the particle-size analysis and the other sample for chemical analyses. This procedure also was implemented for the upland-source and streambank samples. Polyester sieves were used to isolate the $<63 \mu \mathrm{m}$ sediment fractions for fluvial-target, upland-source, and streambank samples. This procedure is necessary because the $<63 \mu \mathrm{m}$ sediment fractions are the most chemically active fraction of sediment (Horowitz, 1991). For every sample, a total of three grams (g) of sediment was sieved and divided into two separate samples for analysis of trace elements $(2 \mathrm{~g})$ and stable carbon and nitrogen isotopes, total carbon, carbonate carbon, and organic carbon by difference $(1 \mathrm{~g})$. Differing sample amounts were based on the sample amounts requested by each laboratory. All individual constituents are listed in table 16. Particle-size analyses 
Table 16. List of constituents used as tracers to identify sources for sediment fingerprinting.

$[\delta$, delta; Elements in bold were the best sediment indicators based on the stepwise linear discriminant analysis; those in parentheses were nonconservative and not included in the stepwise linear discriminant analysis]

\begin{tabular}{|c|c|c|c|c|c|}
\hline \multirow{2}{*}{$\begin{array}{c}\begin{array}{c}\text { Stable isotopes, } \\
\text { in per mil }\end{array} \\
\delta^{13} \text { Carbon }\end{array}$} & \multirow{2}{*}{$\begin{array}{c}\begin{array}{c}\text { Carbon forms, } \\
\text { in milligrams per gram }\end{array} \\
\text { Carbonate }\end{array}$} & \multirow{2}{*}{$\begin{array}{l}\text { Macroelements, } \\
\text { in grams per kilogram } \\
\text { Carbon }\end{array}$} & \multicolumn{3}{|c|}{$\begin{array}{c}\text { Microelements, } \\
\text { in milligrams per kilogram }\end{array}$} \\
\hline & & & Arsenic & Lanthanum & Scandium \\
\hline \multirow{6}{*}{$\delta^{15}$ Nitrogen } & Carbon/nitrogen ratio & Aluminum & Beryllium & Manganese & (Strontium) \\
\hline & & Calcium & Bismuth & Molydenum & Thorium \\
\hline & & Magnesium & Cobalt & Phosphorus & Vandium \\
\hline & & Sodium & Chromium & (Lead) & Tungsten \\
\hline & & Sulfur & Copper & Rubidium & (Yttrium) \\
\hline & & Tungsten & Gallium & Antimony & (Zinc) \\
\hline
\end{tabular}

were conducted by the USGS Kentucky Sediment Laboratory using the pipette method (Guy, 1969). This analysis is used to determine the particle-size distribution of material ranging from 2 to $63 \mu \mathrm{m}$.

Sieved sediment samples were sent to the USGS RSIL in Reston, Va., for stable isotope analyses. Methods for analysis are described in a report by Révész and others (2012). Briefly, stable carbon and nitrogen isotope ratios in solid samples were measured as the gases of carbon dioxide $\left(\mathrm{CO}_{2}\right)$ and nitrogen gas $\left(\mathrm{N}_{2}\right)$ using a high-sensitivity, moderate-resolution magnetic sector mass spectrometer with an ion-bombardment gas source.

Sample analysis for 37 trace elements, stable carbon and nitrogen isotopes, and select carbon-species were conducted by the USGS Central Mineral and Environmental Resources Science Center in Denver, Colo. All samples were freeze dried before submission to the laboratory. Thirty-eight trace elements were analyzed using inductively coupled plasmaatomic emission spectrometry using a mixture of acids at low temperature (Briggs, 2002). The total carbon samples were analyzed by infrared detection using dried, acidified sediment samples. These samples were combusted in an oxygen atmosphere with any carbon present being converted to $\mathrm{CO}_{2}$ gas. The sample gas then flows into a nondispersive infrared detection cell that measures the mass of $\mathrm{CO}_{2}$ gas present (Brown and Curry, 2002). The mass is converted to percentage carbon on the basis of the dry sample weight. Carbonatecarbon sample results were determined by the coulometric titration method (Brown and others, 2002) using platinum and silver/potassium-iodide electrodes. Briefly, each sample is treated with hot perchloric acid and the evolved $\mathrm{CO}_{2}$ gas flows into a cell of monoethanolamine solution that is then colormetrically titrated. Organic carbon concentrations were obtained by the difference between total carbon and carbonatecarbon concentrations.

\section{Statistical Analyses of Sediment Fingerprinting Data}

A series of statistical procedures were used to determine which tracers best differentiated sediment sources (Sloto and others, 2012; Williamson and others, 2014). These procedures included (1) removing outliers from each source group; (2) determining if a tracer's property in each source group was significantly related to grain size and (or) organic carbon content and adjusting for these physical parameters;

(3) bracketing the fluvial-target samples by source type;

(4) identifying the best set of chemical tracers using a stepwise linear discriminant analysis (S-LDA); (5) quantifying the separation of the four sources (cropland, pasture, riparian/ forest, and streambank) using the identified chemical tracers; and (6) determining the percentage contribution of each source using a "mixing" model (table 17). Most statistical analyses used R software (R Development Core Team, 2014); the S-LDA analysis used the MASS and klaR packages of R software (Venables and Ripley, 2002; Weihs and others, 2005). The group goodness-of-fit test used the EnvStats package (Millard, 2015). The final LDA was completed in both R and S-plus (TIBCO, 2008). Details of each analysis are provided below.

The first statistical procedure was to remove outliers from each source group. Using the Shapiro-Wilk test (Shapiro and Wilk, 1965), each tracer in each source group was tested for normality separately. Those variables that were not normally distributed (95-percent confidence interval) were transformed using the inverse, the power, the square root, the inverse square root, or the natural log (Helsel and Hirsch, 2002). The best transformation for normality was selected, and the sample values were transformed. If a transformed value exceeded three times the standard deviation of the average transformed 
Table 17. Outline of field, laboratory, and statistical techniques used to determine sediment sources.

$[<$, less than; $\mu \mathrm{m}$, micrometer $]$

\begin{tabular}{ll}
\hline Field & $\begin{array}{l}\text { Upland area sediment-source sampling-10-20 samples per upland source type } \\
\text { Fluvial (target) sediment sampling using passive sampler }\end{array}$ \\
\hline Laboratory & $\begin{array}{l}\text { Upland source-sediment and fluvial (target) samples sieved to }<63 \mu \mathrm{m} \\
\text { Sediment tracers - trace element analysis using inductively coupled plasma mass spectrometry, stable isotopes, } \\
\text { carbon, nitrogen, phosphorus (table 16) }\end{array}$ \\
\hline Statistical procedures & 1. $\quad$ Outlier removal for each source type using Shapiro-Wilk test ${ }^{1}$ \\
2. & Comparison of size correction test of tracers and \\
& a. median grain size of fine sediment $\left(\mathrm{D}_{50}\right.$ ) using linear regression \\
& b. organic carbon using linear regression \\
3. $\quad$ Bracket test of fluvial (target) samples by source type \\
4. Stepwise linear discriminant analysis (S-LDA) \\
5. Mahalanobis Distance statistic ${ }^{2}$ and posterior error \\
6. Mixing model- using original laboratory data \\
7. Monte-Carlo procedures on mixing model results
\end{tabular}

${ }^{1}$ Shapiro and Wilk (1965).

${ }^{2}$ Rao (1965).

value (Wainer, 1976), the sample was considered an outlier and all tracer results were removed. No outliers were identified, and all 55 source samples were kept.

The property of a sediment tracer depends not only on the source material but also its grain size and amount of organic matter (Collins and others, 2010; Horowitz, 1991). As erosion takes place and sediment is transported through the landscape, the grain size of the material can change. Walling (2005) reported finer grain-sized material being transported out of the basin than found in source areas. Thus, a regression analysis was performed to adjust source chemical characterization to be comparable to the particle-size and organic-matter characteristics of fluvial-target samples (that is, sediment collected in the passive sampler). A linear regression was used to identify any chemical tracer concentrations that varied as a function of median particle size $\left(\mathrm{D}_{50}\right)$ and were adjusted on the basis of the mean $\mathrm{D}_{50}$ values of all fluvial-target samples. A more detailed explanation can be found in Gellis and others (2015).

Sediment fingerprinting requires chemical tracers be conservative and not change during transport from the source area to the sampling point. Consequently, the next step was to perform a bracket test to determine if fluvial-target chemicaltracer values were within the range of those from all 55 source samples. The bracket test was done after a tracer had been adjusted for grain-size and organic carbon relations. Any tracers that did not satisfy this condition within a \pm 1 standard deviation were not considered conservative and were removed from further analysis. Fifteen tracers did not meet the criteria and were removed for further analysis.

An S-LDA was used on normalized datasets to identify the optimal group of tracers. Normalization used a goodnessof-fit test that identified the most common transformation among all the source groups (Millard, 2015), which was then applied to the data. Optimal sets of discriminant tracers were obtained by running the S-LDA 10 times (both backward and forward) because results may vary among runs; the most frequent set of discriminants was used.

Critical tracers from the S-LDA were used in a LDA to confirm each source type was effectively differentiated. The Mahalanobis Distance $\left(\mathrm{D}^{2}\right)$ statistic is a measure of the distance between groups and takes into account covariance among the variables in calculating distances (Rao, 1965). It was used to measure the distance between land-cover types (table 18) and incorporated the covariance among the variables in calculating the distance (De Maesschalck and others, 2000; McLachlan, 1999). In other words, the Mahalanobis Distance statistic verifies that the set of transformed tracers determined by the S-LDA can correctly distinguish each source type (Gellis and Noe, 2013). This statistic has been used in other sediment-fingerprinting investigations (Minella and others, 2008; Gellis and Noe, 2013; Williamson and others, 2014).

A multivariate mixing model (Walling and others, 1999, 2008) was used to estimate the relative contribution of these four sediment sources to individual fluvial-target samples. The critical tracers identified from the S-LDA were used in the mixing model using untransformed tracer values that have been adjusted for $\mathrm{D}_{50}$ and total organic carbon. A weighting factor was calculated for each of the three tracers using methods from Walling and others (2008). A Monte Carlo analysis using 1,000 simulations was used to quantify the uncertainty associated with each allocation of sediment source in order to allow for different parameter combinations that could produce the same goodness-of-fit (Gellis and others, 2015). 
Table 18. Probability that the tracers from the stepwise discriminant function analysis can distinguish between individual source types using the Mahalanobis Distance statistic, ${ }^{1}$ Little River Basin, Kentucky, water years 2013-14.

[Values less than 0.05 indicate that the composite tracers can be used to distinguish between the source types]

\begin{tabular}{lcccc}
\hline & Crop & Pasture & $\begin{array}{c}\text { Riparian/ } \\
\text { Forest }\end{array}$ & Streambank \\
\hline Crop & 1 & $3.32 \times 10^{-13}$ & $9.06 \times 10^{-10}$ & $3.13 \times 10^{-19}$ \\
Pasture & & 1 & $1.23 \times 10^{-17}$ & $1.92 \times 10^{-18}$ \\
Riparian/Forest & & & 1 & $7.19 \times 10^{-10}$ \\
Streambank & & & & 1 \\
\hline \multicolumn{1}{l}{${ }^{1}$ Rao (1965). } & & & &
\end{tabular}

\section{Source Inputs of Suspended Sediment}

Sediment-source samples were collected from 14 streambanks, 26 agricultural areas (13 cropland and 13 pasture), and 15 riparian/forest sites. Each sediment-source sample was analyzed for 45 tracers (table 16). Comparison of $\mathrm{D}_{50}$ to tracer concentrations yielded significant relations for 11 tracers in cropland samples, 19 tracers in pasture samples, 1 tracer in riparian/forest samples, and 3 tracers in streambank samples. Comparisons of total organic carbon to tracer concentration adjusted for grain size indicated significant relations for 4 tracers in cropland samples, 9 tracers in pasture samples, 14 tracers in riparian/forest samples, and 5 tracers in streambank samples. Adjustment factors were applied for those tracers for which concentrations were identified as correlating to grain size and total organic carbon.

Results of the bracket test indicated target samples were not bracketed by 15 tracers that were subsequently removed from further analysis. Three potential tracers to identify sources $\left(\mathrm{d}^{13}\right.$ carbon, calcium, and carbon) were identified by the S-LDA; $\mathrm{d}^{13}$ carbon isotope ratios and calcium were selected in all 10 of the runs and the total carbon concentration in 3 of the runs resulted in a differentiation of the sources between 92.8 and 95.1 percent. Carbon isotope ratios $\left(\delta^{13} \mathrm{C}\right)$, together with calcium and carbon concentrations, were the best indicators of sediment source, with an error $<11$ percent (table 19). The S-LDA results of the Mahalanobis Distance statistical test indicated the set of three normalized tracers was able to discriminate between the source types (cropland, pasture, riparian/forest, streambank) ( $p$-value $<0.05$ ) (table 18). Pasture was the source material most effectively differentiated and the cropland and streambank sources were the most difficult to differentiate. Overall, the S-LDA successfully classified 52 of 55 of the source samples in their source-area category using 3 tracers and misclassified 3 samples.

The mixing model was applied to differentiate the relative contribution of suspended sediment from each of four source types to the fine-grained sediment $(<63 \mathrm{~mm})$ collected in the passive sediment samplers. The contribution of individual sources ranged from 0 to 84 percent; the maximum standard deviation was 3.8 percent.

The dominant sources contributing to fine-grained sediment varied among the sites. Fine-sediment source proportions from the four individual land-cover types are shown in table 20. Within the SFLR Basin at site SF01 (headwater site), cropland was the primary contributor of fine sediment followed by pasture and riparian/forest during the sampling period May 2013 to January 2014 (table 20; fig. 25). Between 2011 and 2013, land use in close proximity upstream from site SF01 was converted to cropland from forest. The model results of source proportions from site SF02, which is downstream from site SF01 on the main stem, showed streambanks and riparian/forest source areas to be important fine-sediment contributors (fig. 25; table 20). Sampling periods were the same at sites SF01 and SF02; however, each site showed noticeably different source proportions (table 20). At site SF09, fine-sediment sources were collected during the sampling periods May 2013 to January 2014 and March 2014 to October 2014. In 2014, the passive sampler at site SF09 was reinstalled in March before site SF14 (only other site in 2014) because site SF14 was not easily accessible until July. The largest proportion of fine sediment at site SF09 during the May 2013 to January 2014 sampling period was from cropland (fig. 25; table 20). Results from the March 2014 to October 2014 sampling period at site SF09 showed streambank as the most important contributor (fig. 25; table 20), possibly because higher streamflow in March and April contributed to increased streambank contributions. The variability of fine-sediment contributions between the sampling periods potentially reflects the timing of sample collection, the type of tillage practices, the frequency and magnitude of high streamflow events, and the importance of contributions from

Table 19. Average elemental source concentration plus standard error for the normalized sediment fingerprinting properties included in the mixing model for the four upland-source types.

$[n=$ sample number $]$

\begin{tabular}{ccccr}
\hline $\begin{array}{c}\text { Elemental fingerprinting } \\
\text { property }\end{array}$ & $\begin{array}{c}\text { Cropland } \\
(\boldsymbol{n}=\mathbf{1 3})\end{array}$ & $\begin{array}{c}\text { Pasture } \\
(\boldsymbol{n}=\mathbf{1 3})\end{array}$ & $\begin{array}{c}\text { Riparian } \\
(\boldsymbol{n}=\mathbf{1 5})\end{array}$ & $\begin{array}{c}\text { Streambanks } \\
(\boldsymbol{n}=\mathbf{1 4})\end{array}$ \\
\hline${ }^{13}$ Carbon & $-22.52 \pm 0.338$ & $-18.6 \pm 0.505$ & $-26.8 \pm 0.280$ & $-24.6 \pm 0.225$ \\
Carbon & $0.917 \pm 0.043$ & $1.56 \pm 0.156$ & $2.65 \pm 0.184$ & $1.27 \pm 0.080$ \\
Calcium & $0.279 \pm 0.010$ & $0.03 \pm 0.085$ & $0.326 \pm 0.022$ & $0.590 \pm 0.032$ \\
\hline
\end{tabular}




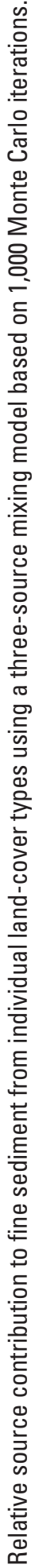

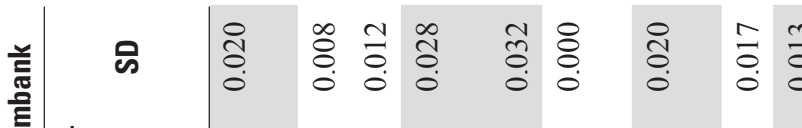

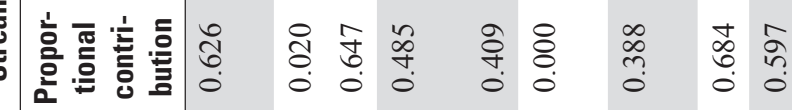

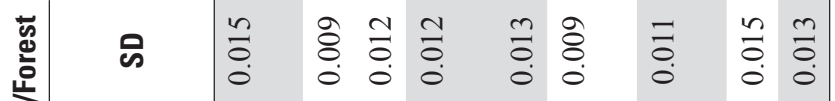

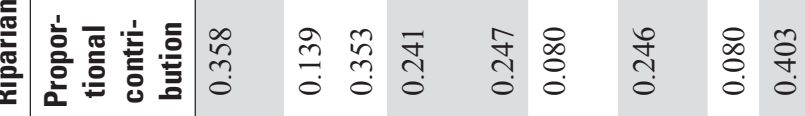

म $\quad \begin{array}{lllllllll}\overline{0} & 8 & 8 & 0 & 0 & \hat{8} & 8 & \infty & 8 \\ 0 & 8 & 8 & 8 & 0 & 0 & 0 & 0 & 8 \\ 0 & 0 & 0 & 0 & 0 & 0 & 0 & 0 & 0\end{array}$

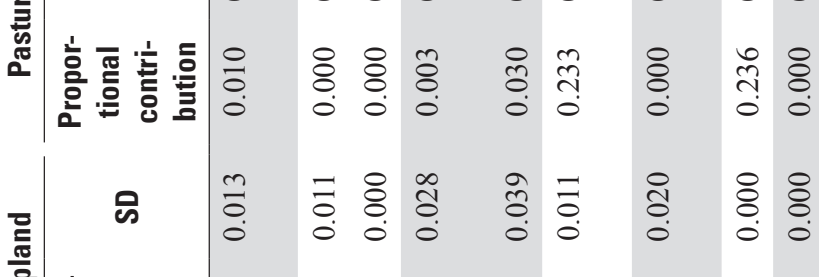

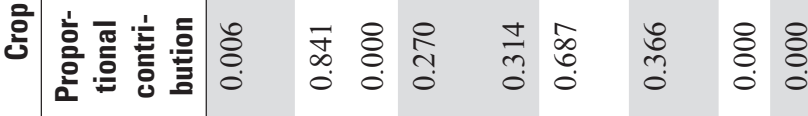

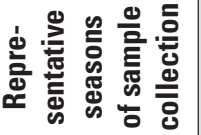

离离离 离

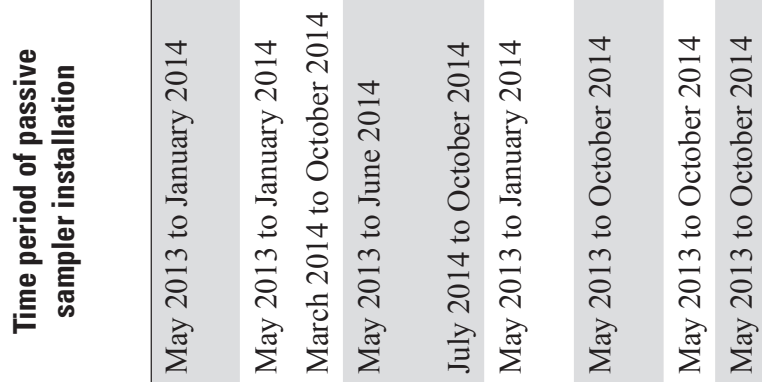

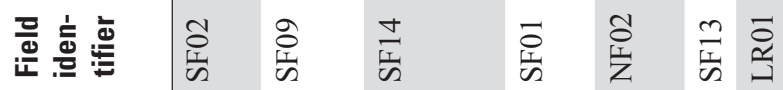

岌

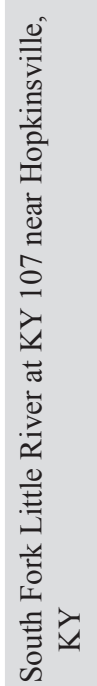

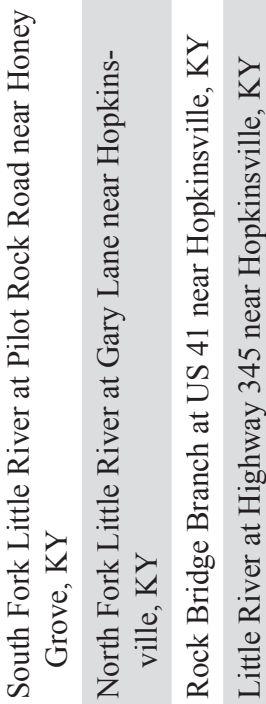




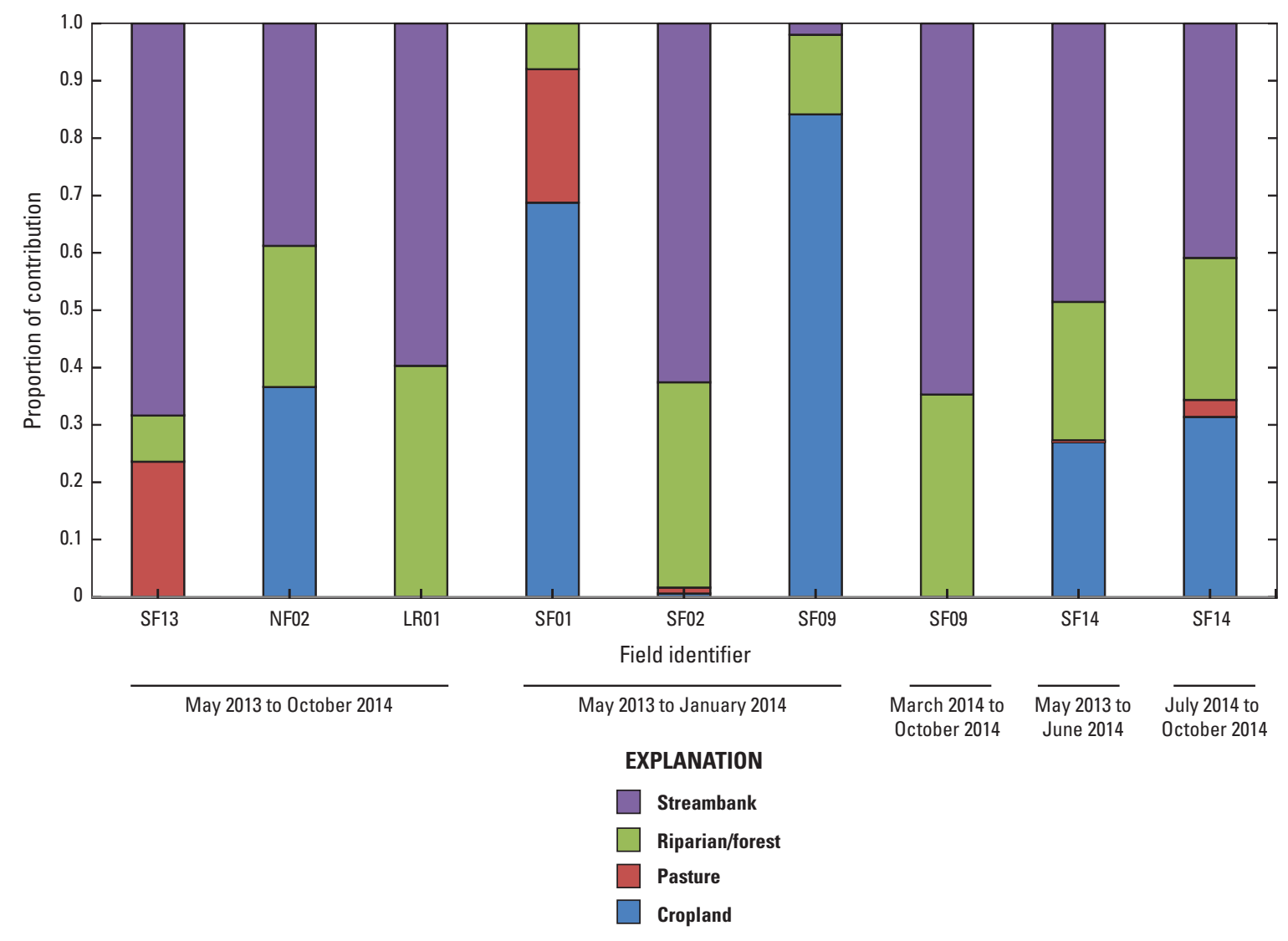

Figure 25. Sediment-source contributions based on a four-source mixing model in the North Fork Little River, South Fork Little River, and Little River Basins, Kentucky, water years 2013-14.

streambank erosion as compared to the transport of sediment through different areas of the basin. Similarly, fine-sediment samples collected during the sampling period May 2013 to October 2014 at site SF13 indicated streambanks (68 percent) as the major source with pasture the next largest contributor (24 percent). Riparian/forest source areas had minor contributions of 8 percent. Fluvial samples were collected at site SF14 (basin outlet) during the sampling periods May 2013 to June 2014 and July 2014 to October 2014. Samples from each sampling period indicated streambanks as the largest source of the fine sediment to the stream followed by cropland and riparian/forest-source areas, respectively; pasture was a minor, but identifiable, contributing source.

Sampling activities were limited to one sampling period (May 2013 to October 2014) across three seasons at the outlet of the NFLR (site NF02) and on the Little River main stem (site LR01) just below the confluence of the NFLR and the SFLR. However, caution should be applied in interpreting the proportional breakdown of the fine-sediment sources at these sites, because the source material used for differentiation of sources was collected in the SFLR Basin.

The result of the fine-sediment sample collected at site NF02 (basin outlet) indicated two essentially equal contributors of fine sediment to the stream were streambanks and cropland at about 37 percent each, with the remainder identified as riparian/forest. At site LR01, sampling revealed streambanks were the dominant sediment source (60 percent); the remainder was contributed from riparian/forest areas. Because site LR01 is downstream from the confluence of sites NF02 and SF14, it was initially thought the relative fine-sediment contributions would be similar to those from the upstream basins. Although high proportions of streambank and riparian/ forest source areas were identified as major contributors at all three sites; cropland was not identified as a fine-sediment contributing source at site LR01 as it was in the upstream basins. Discrepancies can possibly be explained by fine-sediment contributions at site NF02 reflecting the riparian/forest land use within the immediate proximity of the sample collection site and (or) the amount of sediment eroded from cropland-source areas in the upstream basins was being delivered to site LR01 but going into storage.

Sediment-source tracking studies in other locations have indicated that streambank is most frequently the largest proportional contributor to suspended sediment during sampled events. However, in the Little River basin, there is a site where cropland is identified as the source of greater than 80 percent of the suspended sediment (for example, SF09). Notably, the cropland proportion is largest for those samples that included 
winter collection, when the soil-surface is most likely to be exposed. Agricultural land, combining both cropland and pasture, contributes a similar proportion of sediment at the more downstream sites (for example, NF02 and SF14) as is contributed by the streambank. Finally, pasture, the most clearly differentiated source, contributes greater than 20 percent of suspended sediment in the winter at SF01 (a headwater tributary) and in the fall at SF13 (near the confluence with NFLR).

\section{Limitations Using Sediment Fingerprinting}

Although the results of sediment fingerprinting can provide resource managers with information on the most important sources, the approach does have limitations. The principal limitation in using the sediment-fingerprinting approach is the ability to sufficiently identify, sample, and statistically differentiate the chemical signature of the upland-sediment source areas and fluvial sediment samples with conservative tracers (Gellis and others, 2015). As sediment moves through the landscape, biological, chemical, and physical processes take place that can potentially change the properties of the tracers; the methods used in this study worked to account for this potential with a combination of grain-size and organic-carbon adjustments combined with elimination of chemical tracers that are not conservative. Another limitation is the statistical procedure(s) used to determine which tracers are the most important in defining the upland-sediment sources. Although the most statistically significant combination of indicators was selected, other combinations of indicators may alter the interpretation, especially when additional land-uses, like roads, landfills, and multiple types of livestock operations, are also contributing sediment to the stream channel. However, use of the Monte Carlo procedure in determining contributions of individual upland-sediment sources has decreased this uncertainty - a weaker differentiation among sources would give larger standard deviations for each source resulting in ranges that overlap. Finally, caution should be used when interpreting the results because understanding the biological, chemical, and physical processes, combined with spatial variability in land management is complex and may not account for temporal variability (Gellis and others, 2015). As in this study, limited fluvial sediment samples and different sampling periods also may not account for temporal variability.

\section{Part 5-Summary and Conclusions}

Because the South Fork Little River (SFLR) and North Fork Little River (NFLR) Basins are listed on the 303(d) List of Waters for Kentucky Report to Congress for pathogen, nutrient, and sediment impairments, the Little River WaterQuality Consortium (LRWQC) required additional waterquality information to begin preparing a Watershed Plan for focusing effective best-management practices in targeted areas of the basins. In cooperation with the LRWQC, the
U.S. Geological Survey (USGS) conducted a 3-year study (2-years of data collection) from water years 2013-14 in the SFLR and NFLR Basins to aid in understanding the occurrence and distribution of pathogens, nutrients, and sediment and their potential sources. The main focus of the study was in the SFLR Basin, which has a higher percentage of cropland and increasing numbers of small dairy operations.

Discrete water-quality, suspended sediment, stable isotope, fecal-indicator bacteria (FIB), and sediment fingerprinting samples were collected at a combination of some or all of 19 sites on a monthly basis following standard USGS methods. However, FIB in water and fluvial sediments, microbialsource tracking, and host-source samples were only collected during the recreation season (May to October) each year. Site selection was based on land-use type, areas of known or expected sources, and the confluence of tributaries.

Samples collected for FIB in water and fluvial sediment could not be evaluated by Kentucky current recreation waterquality criteria, because Kentucky recreational water-quality FIB criteria are based on multiple samples collected within 30 days. Instead, a statistical threshold value (STV) issued by the U.S. Environmental Protection Agency (EPA) was used, which is based on a percentage of samples exceeding a statistical percentile. Bacteroidales-based 16S ribosomal ribonucleic acid genetic markers were used as a tool to provide information on whether FIB sources likely originated from human or nonhuman sources. Surface-water samples were collected and analyzed for Bacteroidales genetic markers (General AllBac, Human HF183, Ruminant BoBac, Canid BacCan, and Waterfowl) to identify potential sources of fecal contamination from humans, ruminants, canids, and waterfowl. The human-associated marker (HF183) was found above the detection limit in 26 percent of samples $(n=120$ samples); a higher proportion of positive samples was found at the NFLR Basin outlet site than at SFLR Basin sites. The ruminant-associated marker (BoBac) was found above the detection limit in 65 percent of samples: the majority of positive results were in the headwaters of the SFLR Basin. The waterfowl marker was not detected in any sample.

Prior to load estimation, nutrient concentrations were evaluated and compared among sites in the SFLR and NFLR Basins. The majority of TN and TP concentrations were above the EPA recommended criteria of $0.69 \mathrm{mg} / \mathrm{L}$ as nitrogen and $0.037 \mathrm{mg} / \mathrm{L}$ as phosphorus for the nutrient ecoregion IX, respectively. Concentrations of TN exceeded the recommended criteria in about 90 percent of the samples collected in the SFLR Basin and all samples in the NFLR Basin. Concentrations of nitrate comprised 76 percent of the median TN concentration for all sites. Elevated ammonia $\left(\mathrm{NH}_{4}^{+}\right)$concentrations in streams may increase concentrations of un-ionized ammonia $\left(\mathrm{NH}_{3}\right)$, which can kill fish and other aquatic life. However, only concentrations of total ammonia $\left(\mathrm{NH}_{3}+\mathrm{NH}_{4}{ }^{+}\right)$ are reported in this report. Concentrations of TP exceeded the recommended criteria in 67 percent of all samples in the SFLR Basin and 98 percent of all samples in the NFLR Basin. 
Concentrations of orthoP comprised 47 percent of the median

$\mathrm{TP}$ concentration for all sites.

Nutrient loads and yields differed between the SFLR and NFLR Basins, even though the basins have similar drainage areas. The SFLR Basin $\left(67.4 \mathrm{mi}^{2}\right)$ had an estimated TN mean annual load of 1,080,000 lb/yr, and the NFLR Basin $\left(58.1 \mathrm{mi}^{2}\right)$ had an estimated mean annual load of 730,000 lb/yr. The SFLR Basin produced the largest estimated mean yields of $\mathrm{TN}\left(16,000 \mathrm{lb} / \mathrm{yr} / \mathrm{mi}^{2}\right)$ and $\mathrm{NO}_{2}+\mathrm{NO}_{3}\left(12,500 \mathrm{lb} / \mathrm{yr} / \mathrm{mi}^{2}\right)$. The NFLR Basin produced the largest estimated mean yields of $\mathrm{NH}_{4}^{+}+\operatorname{orgN}\left(4,700 \mathrm{lb} / \mathrm{yr} / \mathrm{mi}^{2}\right), \mathrm{TP}\left(1,100 \mathrm{lb} / \mathrm{yr} / \mathrm{mi}^{2}\right)$, and orthoP $\left(590 \mathrm{lb} / \mathrm{yr} / \mathrm{mi}^{2}\right)$.

Nitrate sources in surface water were assessed in both basins using dual-nitrate isotopes (nitrogen and oxygen) ratios. Data from the different land uses in the SFLR Basin showed differences in nitrate concentrations and overlapping but moderately distinct isotopic signatures. Predominantly forested sites consistently had low concentrations of nitrate with minimal variability, and agricultural sites had the highest nitrate concentrations with the greatest variability. Dual-isotope data from forested sites plotted within ranges characteristic of soilderived nitrate with possible, but minimal, influence from the atmosphere. Ranges of dual-isotope data from agricultural and mixed-land-use sites were characteristic of possible mixtures of chemical fertilizer, soil-derived nitrate, and manure and septic wastes. In the NFLR Basin, a positive linear relation was observed between nitrate concentrations and $\delta^{15} \mathrm{~N}_{\mathrm{NO} 3}$ values that potentially suggest the NFLR has a higher proportion of $\delta^{15} \mathrm{~N}_{\mathrm{NO} 3}$ enriched sources, such as manure and sewage. However, mixing of other nitrate-derived sources cannot be excluded because many values of $\delta^{15} \mathrm{~N}_{\mathrm{NO} 3}$ and concentrations of nitrate showed minimal variation and plotted within dualnitrate isotopes ranges characteristic of fertilizer and soilderived nitrate sources.

A sediment-fingerprinting approach was used to quantify the relative contribution of four upland sources in the SFLR Basin (cropland, pasture, riparian/forest, and streambank) in order to understand how land management affects suspendedsediment concentration. Out of 45 potential tracers that were considered, carbon isotope ratio $\left(\delta^{13} \mathrm{C}\right)$, calcium concentrations, and carbon concentrations were the best indicators of sediment source. Fine-sediment samples collected at the SFLR outlet indicated streambanks as the largest source of the fine sediment to the stream followed by cropland and riparian/ forest source areas, respectively; pasture was only a minor contributing source. Streambanks and cropland were essentially equal contributors of fine sediment at the NFLR outlet. Caution should be applied in interpreting the proportional breakdown of the fine-sediment sources because timing of the sample collection may affect the sources identified. Additionally, upland source samples were all collected in the SFLR.

This study was intended to provide information to the LRWQC about potential sources of FIB, nutrients, and sediment to impaired streams in the SFLR and NFLR Basins through application of multiple-source tracking approaches for the development of a Watershed Plan. This type of plan aids in the implementation of effective management activities in working toward an environmentally and economically healthy watershed.

\section{References Cited}

ASTM, 2006, D 3977-97, Standard test methods for determining sediment concentration in water samples: Water and Environmental Technology, v. 11.02, 7 p.

Bateman, A.S., and Kelly, S.D., 2007, Fertilizer nitrogen isotope signatures: Isotopes in Environmental and Health Studies, v. 43, no. 3, p. 237-247, accessed August 2016 at https://doi.org/10.1080/10256010701550732.

Böhlke, J.K., Mroczkowski, S.J., and Coplen, T.B., 2003, Oxygen isotopes in nitrate- -New reference materials for 18O:17O:16O measurements and observations on nitratewater equilibration: Rapid Communications in Mass Spectrometry, v. 17, no. 16, p. 1835-1846, accessed August 2016 at https://doi.org/10.1002/rcm.1123.

Böttcher, J., Strebel, O., Vorkelius, Susanne, and Schmidt, H.L., 1990, Using isotope fractionation of nitratenitrogen and nitrate-oxygen for evaluation of microbial denitrification in a sandy aquifer: Journal of Hydrology, v. 114, no. 3-4, p. 413-424, accessed August 2016 at http://dx.doi.org/10.1016/0022-1694(90)90068-9.

Briggs, P.H., 2002, The determination of forty-four elements in geological and botanical samples by inductively coupled-plasma-atomic emission spectrometry, in Taggart, J.E., Jr., ed., Analytical methods for the chemical analysis of geologic and other materials: U.S. Geological Survey Open-File Report 02-0223, chap. G, 18 p., accessed July 2015, at http://pubs.usgs.gov/of/2002/ofr-02-0223/ OFR-02-0223.pdf.

Brown, Z.A., and Curry, K.J., 2002, Total carbon by combustion, chap. R of Taggart, J.E., Jr., ed., Analytical methods for the chemical analysis of geologic and other materials: U.S. Geological Survey Open-File Report 02-0223, 4 p., accessed July 2015 at http://pubs.usgs.gov/of/2002/ ofr-02-0223/OFR-02-0223.pdf.

Brown, Z.A., Papp, Clara, Brandt, Elaine, and Aruscavage, Phillip, 2002, Carbonate carbon by coulometric titration, chap. S of Taggart, J.E., Jr., ed., Analytical methods for the chemical analysis of geologic and other materials: U.S. Geological Survey Open-File Report 02-0223, 6 p., accessed July 2015 at http://pubs.usgs.gov/of/2002/ ofr-02-0223/OFR-02-0223.pdf. 
Burns, D.A., Boyer, E.W., Elliott, E.M., and Kendall, Carol, 2009, Sources and transformations of nitrate from streams draining varying land uses_-Evidence from dual isotope analysis: Journal of Environmental Quality, v. 38, p. 11491159, accessed August 2016 at https://doi.org/10.2134/ jeq2008.0371.

Casciotti, K.L., Sigman, D.M., Hastings, M.G., Böhlke, J.K., and Hilkert, A., 2002, Measurement of the oxygen isotopic composition of nitrate in seawater and freshwater using the denitrifier method: Analytical Chemistry, v. 74, no. 19, p. 4905-4912.

Cinotto, P.J., 2005, Occurrence of fecal-indicator bacteria and protocols for identification of fecal-contamination sources in selected reaches of the West Branch Brandywine Creek, Chester County, Pennsylvania: U.S. Geological Survey Scientific Investigations Report 2005-5039, 91 p. [Also available at https://pubs.usgs.gov/sir/2005/5039/.]

Collins, A.L., Walling, D.E., and Leeks, G.J.L., 1997, Sediment sources in the upper Severn catchment-A fingerprinting approach: Hydrology and Earth System Sciences, v. 1 no. 3, p. 509-521, accessed August 2016 at https://doi.org/10.5194/hess-1-509-1997.

Collins, A.L., Walling, D.E., Webb, L., and King, P., 2010, Apportioning catchment scale sediment sources using a modified composite fingerprinting technique incorporating property weightings and prior information: Geoderma, v. 155 , p. $249-261$.

Coplen, T.B., Qi, Haiping, Révész, Kinga, Casciotti, Karen, and Hannon, J.E., 2012, Determination of the $\delta 15 \mathrm{~N}$ and $\delta 180$ of nitrate in water; RSIL lab code 2900 , chap. 17 of Stable isotope-ratio methods, sec. C of Révész, Kinga, and Coplen, T.B. eds., Methods of the Reston Stable Isotope Laboratory: U.S. Geological Survey Techniques and Methods, book 10, 35 p, available only at http://pubs.usgs.gov/ $\mathrm{tm} / 2006 / \mathrm{tm} 10 \mathrm{c} 17 /$.

Craig, N.J., and Kuenzler, E.J., 1983, Land use, nutrient yield, and eutrophication in the Chowen River Basin: Raleigh, N.C., Water Resources Research Institute of the University of North Carolina, Report No. 205.

Crain, A.S., 2001, Estimated loads and yields of suspended soils and water-quality constituents in Kentucky streams: U.S. Geological Survey Water-Resources Investigations Report 2001-4075, 125 p. [Also available at http://pubs.er.usgs.gov/publication/wri014075/.]

Crain, A.S., 2006, Concentrations, and estimated loads and yields of nutrients and suspended sediment in the Little River Basin, Kentucky, 2003-04: U.S. Geological Survey Scientific Investigations Report 2006-5204, 31 p.
Crain, A.S., Cherry, M.A., Williamson, T.N., and Bunch, A.R., 2017, Sources of pathogens, nutrients, and sediment in the Upper Little River Basin, Kentucky (2012-14): U.S. Geological Survey data release, accessed April 2017 at https://doi.org/10.5066/F7ZS2TPW.

Cravotta, C.A., III, 1997, Use of stable isotopes of carbon, nitrogen, and sulfur to identify sources of nitrogen in surface waters in the lower Susquehanna River Basin, Pennsylvania: U.S. Geological Survey Water-Supply Paper 2497, 99 p. [Also available at https://pubs.usgs.gov/wsp/wsp2497/ pdf/wsp2497.pdf.]

De Maesschalck, R., Jouan-Rimbaud, D., and Massart, D.L., 2000, The Mahalanobis distance: Chemometrics and Intelligent Laboratory Systems, v. 50, no. 1, p. 1-18, accessed July 2015 at http://dx.doi.org/10.1016/ S0169-7439(99)00047-7.

Devereux, O.H., Prestegaard, K.L., Needelman, B.A., and Gellis, A.C., 2010, Suspended-sediment sources in an urban watershed, Northeast Branch Anacostia River, Maryland: Hydrological Processes, v. 24, no. 11, p. 1391-1403, accessed July 2015 at https://doi.org/10.1002/hyp.7604.

Dick, L.K, and Field, K.G., 2004, Rapid estimation of numbers of fecal Bacteroidetes by use of a quantitative PCR assay for 16S rRNA genes: Applied and Environmental Microbiology, v. 70, no. 8, p. 5695-5697, accessed October 2015 at https://doi.org/10.1128/AEM.70.9.5695-5697.2004.

Ding, Jingtao, Xi, Beidou, Gao, Rutai, He, Liansheng, Liu, Hongliang, Dai, Xuanli, and Yu, Yijun., 2014, Identifying diffused nitrate sources in a stream in an agricultural field using a dual isotopic approach: Science of the Total Environment. v. 484, p. 10-18, accessed August 2016 at http://dx.doi.org/10.1016/j.scitotenv.2014.03.018.

Fishman, M.J., ed., 1993, Methods of analysis by the U.S. Geological Survey National Water Quality LaboratoryDetermination of inorganic and organic constituents in water and fluvial sediments: U.S. Geological Survey OpenFile Report 93-125, 217 p.

Fogg, G.E., Rolston, D.E., Decker, D.L., Louie, D.T., and Grismer, M.E., 1998, Spatial variation in nitrogen isotope values beneath nitrate contamination sources: Groundwater, v. 36, no. 3, p. 418-426, accessed August 2016 at https://doi.org/10.1111/j.1745-6584.1998.tb02812.x.

Francy, D.S., and Darner, R.A., 1998, Factors affecting Escherichia coli concentrations at Lake Erie public bathing beaches: U.S. Geological Survey Water Resources Investigations Report 98-4241, 41 p.

Frazier, W.J., and Schwimmer, D.R., 1987, Regional stratigraphy of North America: New York, Plenum Press, 744 p. 
Fry, J., Xian, G., Jin, S., Dewitz, J., Homer, C., Yang, L., Barnes, C., Herold, N., and Wickham, J., 2011, Completion of the 2006 national land cover database for the conterminous United States: PE\&RS, v. 77, no. 9, p. 858-864.

Gellis, A.C., Hupp, C.R., Pavich, M.J., Landwehr, J.M., Banks, W.S.L., Hubbard, B.E., Langland, M.J., Ritchie, J.C., and Reuter, J.M., 2009, Sources, transport, and storage of sediment at selected sites in the Chesapeake Bay watershed: U.S. Geological Survey Scientific Investigations Report 2008-5186, 95 p.

Gellis, A.C., and Noe, G.B., 2013, Sediment source analysis in the Linganore Creek watershed, Maryland, USA, using the sediment fingerprinting approach-2008 to 2010: Journal of Soils and Sediments, v. 13, no. 10, p. 1735-1753, accessed July 2016 at https://doi.org/10.1007/s11368-013-0771-6.

Gellis, A.C., Noe, G.B., Clune, J.W., Myers, M.K., Hupp, C.R., Schenk, E.R., and Schwarz, G.E., 2015, Sources of fine-grained sediment in the Linganore Creek watershed, Frederick and Carroll Counties, Maryland, 2008-10: U.S. Geological Survey Scientific Investigations Report 2014-5147, 56 p., https://doi.org/10.3133/sir20145147.

Green, H.C., Dick, L.K., Gilpin, Brent, Samadpour, Mansour, and Field, K.G., 2012, Genetic markers for rapid PCR-based identification of gull, Canada goose, duck, and chicken fecal contamination in water: Applied and Environmental Microbiology, v. 78, no. 2, p. 503-510, accessed October 2015 at https://doi.org/10.1128/AEM.05734-11.

Guy, H.P., 1969, Laboratory theory and methods for sediment analysis: U.S. Geological Survey Techniques of WaterResources Investigations, book 5, chap. C1, 58 p. [Also available at http://pubs.er.usgs.gov/publication/twri05C1/.]

Hanchar, D.W., 1991, Effects of septic-tank effluent on ground-water quality in Northern Williamson County and Southern Davidson County, Tennessee: U.S. Geological Survey Water-Resources Investigations Report 1991-4011, $15 \mathrm{p}$.

Harrington, D.P., and Fleming, T.R., 1982, A class of rank test procedures for censored survival data: Biometrika, v. 69, no. 3, p. 553-566, accessed August 2015 at https://doi.org/10.1093/biomet/69.3.553.

Helsel, D.R., 2012, Statistics for censored environmental data using Minitab and R ( $2 \mathrm{~d}$ ed.): New York, John Wiley \& Sons, Inc., 324 p.

Helsel, D.R., and Cohn, T.A., 1988, Estimation of descriptive statistics for multiply censored water quality data: Water Resources Research, v. 24, no. 12, p. 1997-2004.

Helsel, D.R., and Hirsch, R.M., 2002, Statistical methods in water resources: U.S. Geological Survey Techniques of Water Resources Investigations, book 4, chap. A3, 522 p.
Hoos, A.B., Robinson, J.A., Aycock, R.A., Knight, R.R., and Woodside, M.D., 1999, Sources, instream transport, and trends in nitrogen, phosphorus, and sediment in the Lower Tennessee River Basin, 1980-96: U.S. Geological Survey Water-Resources Investigation Report 99-4139, 96 p.

Horowitz, A.J., 1991, A primer on sediment trace element chemistry ( $2 \mathrm{~d}$ ed.): U.S. Geological Survey Open-File Report 91-76, $136 \mathrm{p}$.

IDEXX Laboratories, 2009, Quanti-Tray procedure: Westbrook, Maine, accessed June 2014 at http://www.idexx.com/ pubwebresources/pdf/en_us/water/0602030.pdf.

J.R. Wauford and Company Consulting Engineers, Inc., and JV Engineering, Inc., 2015, Regional facility plan update related to the expansion of the Hammond Wood wastewater treatment plant: Nashville, Tenn., accessed August 2016 at http://water.ky.gov/Documents/PublicHearing/HWEA\%20 FP\%20020515\%20Pt\%201.pdf.

Kaushal, S.S., Groffman, P.M., Band, L.E., Elliott, E.M., Shields, C.A., and Kendall, Carol, 2011, Tracking nonpoint source nitrogen pollution in human-impacted watersheds: Environmental. Science and Technology, v. 45, no. 19, p. $8225-8232$.

Kellman, L.M., and Hillaire-Marcel, C., 2003, Evaluation of nitrogen isotopes as indicators of nitrate contamination sources in an agricultural watershed: Agriculture, Ecosystems, \& Environment, v. 95, no. 1, p. 87-102.

Kelly, V.J., Hooper, R.P., Aulenbach, B.T., and Janet, Mary, 2001, Concentrations and annual fluxes for selected water-quality constituents from the USGS National Stream Quality Accounting Network (NASQAN), 1996-2000: U.S. Geological Survey Water-Resources Investigations Report 2001-4255, accessed January 2016 at http://pubs.usgs.gov/ wri/wri014255/toc.htm.

Kendall, Carol, 1998, Tracing nitrogen sources and cycles in catchments, in chap. 16 of Kendall, Carol, and McDonnell, J.J., eds., Isotope tracers in catchment hydrology: Amsterdam, The Netherlands, Elsevier, p. 519-576.

Kendall, Carol, Elliott, E.M., and Wankel, S.D., 2007, Tracing anthropogenic inputs of nitrogen to ecosystems, in Michener, R.H., and Lajtha, Kate, eds., Stable isotopes in ecology and environmental science (2d ed.): Oxford, U.K., Wiley-Blackwell Publishing, accessed January 2016 at https://doi.org/10.1002/9780470691854.ch12.

Kennedy, E.J., 1983, Computation of continuous records of streamflow: U.S. Geological Survey Techniques of WaterResources Investigations, book 3, chap. A13, 53 p. [Also available at https://pubs.usgs.gov/twri/twri3-a13/.] 
Kentucky Administrative Regulations (KAR), 2008, Title 401, chapter 10, regulation 031-Surface water standards: Kentucky Legislature web page, accessed June 5, 2017, at http://lrc.ky.gov/kar/title401.htm.

Kentucky Division of Geographic Information, 2007, Kentucky 2005 land cover-Anderson level II: Commonwealth of Kentucky, Frankfort, Ky., accessed July 9, 2016, at ftp.kymartian.ky.gov/kls/KY_LC2005.zip.

Kentucky Energy and Environment Cabinet, 2009, Little River Watershed, Lower Cumberland Basin report: Commonwealth of Kentucky, Frankfort, Ky., accessed July 26, 2015, at http://water.ky.gov/waterquality/Pages/ApprovedTMDLs. aspx?Paged $=$ TRUE\&p_Title=TMDL $\% 20$ Craborchard $\% 20$ Creek\%20of\%20Drakes\%20Creek\&p_ID=16\&PageFi rstRow $=21 \& \&$ View $=\{212539 \mathrm{DB}-1 \mathrm{AE} 8-4 \mathrm{~F} 1 \mathrm{D}-\mathrm{A} 55 \mathrm{~B}-$ F2F01642517D.

Kildare, B.J., Leutenegger, C.M., McSwain, B.S., Bambic, D.G., Rajal, V.B., and Wuertz, Stefan, 2007, 16S rRNAbased assays for quantitative detection of universal, human-, cow-, and dog-specific fecal BacteroidalesA Bayesian approach: Water Research, v. 41, no. 16, p. 3701-3715, accessed October 2015 at http://dx.doi. org/10.1016/j.watres.2007.06.037.

Kruskal, W.H., and Wallis, W.A., 1952, Use of ranks in onecriterion variance analysis: Journal of the American Statistical Association, v. 47, no. 260, p. 583-621, accessed April 2017 at http://dx.doi.org/10.2307/2280779.

Layton, Alice, McKay, Larry, Williams, Dan, Garrett, Victoria, Gentry, Randall, and Sayler, Gary, 2006, Development of Bacteroides 16S rRNA gene TaqMan-based real-time PCR assays for estimation of total, human, and bovine fecal pollution in water: Applied and Environmental Microbiology, v. 72 , no. 6 , p. $4214-4224$.

Lorenz, D.L., 2015, smwrBase-An R package for managing hydrologic data, version 1.1.1: U.S. Geological Survey Open-File Report 2015-1202, 7 p., http://dx.doi.org/10.3133/ofr20151202.

Mahon, G.L., 2011, Assessment of groundwater pathways and contaminant transport in Florida and Georgia using multiple chemical and microbiological indicators: U.S. Geological Survey Fact Sheet 2011-3070, http://pubs.usgs.gov/ fs/2011/3070/. (Available online only).

Mayer, Bernhard, Boyer, E.W., Goodale, Christine, Jaworski, N.A., Van Breeman, Nico, Howarth, R.W., Seitzinger, Sybil, Billen, Gilles, Lajtha, Kate, Nadelhoffer, Knute, Van Dam, Douwe, Hetling, L.J., Nosal, Miloslav, and Paustian, Keith, 2002, Sources of nitrate in rivers draining sixteen watersheds in the northeastern U.S.- Isotopic constraints: Biogeochemistry, v. 57-58, p. 171-197.
Mayer, Bernhard, and Wassenaar, L.I., 2012, Isotopic characterization of nitrate sources and transformations in Lake Winnipeg and its contributing rivers, Manitoba, Canada: Journal of Great Lakes Research, v. 38, p. 135-146, http://dx.doi.org/10.1016/j.jglr.2012.02.004.

McDowell, R.C., ed., 1986, The geology of Kentucky; a text to accompany the geologic map of Kentucky: U.S. Geological Survey Professional Paper 1151-H, 76 p., accessed October 2016 at https://pubs.usgs.gov/prof/p1151h/.

McLachlan, G.J., 1999, Mahalanobis distance: Resonance Journal of Science Education, v. 4, p. 20-26.

Millard, S.P., 2015, EnvStats—Package for environmental statistics, including US EPA guidance: R package, http://www.probstatinfo.com.

Miller, L.D., and Ortiz, R.F., 2007, Ground-water quality and potential effects of individual sewage disposal system effluent on ground-water quality in Park County, Colorado, 2001-2004: U.S. Geological Survey Scientific Investigations Report 2007-5220, 48 p. [Also available at https://pubs.usgs.gov/sir/2007/5220/index.html.]

Minella, J.P.G., Walling, D.E., and Mertin, G.H., 2008, Combining sediment source tracing techniques with traditional monitoring to assess the impact of improved land management on catchment sediment yields: Journal of Hydrology, v. 348, no. 3-4, p. 546-563, accessed August 2015 http://dx.doi.org/10.1016/j.jhydrol.2007.10.026.

Motha, J.A., Wallbrink, P.J., Hairsine, P.B., and Grayson, R.B., 2003, Determining the sources of suspended sediment in a forested catchment in southeastern Australia: Water Resources Research, v. 39, no. 3, p. 1056.

Mueller, D.K., and Helsel, D.R., 1996, Nutrients in the Nation's waters-Too much of a good thing?: U.S. Geological Survey Circular 1136, 24 p. [Also available at http://pubs.usgs.gov/circ/circ1136/.]

Mukundan, Rajith, Walling, D.E., Gellis, A.C., Slattery, M.C., and Radcliffe, D.E., 2012, Sediment source fingerprinting-Transforming from a research tool to a management tool: Journal of American Water Resources Association, v. 48 , no. 6, p. 1241-1257, accessed, August 2015, at https://doi.org/10.1111/j.1752-1688.2012.00685.x.

Myers, D.N., Stoeckel, D.M., Bushon, R.N., Francy, D.S., and Brady, A.M.G., 2007, Fecal indicator bacteria (ver. 2.0): U.S. Geological Survey Techniques of Water-Resources Investigations, book 9, chap. A7, section 7.1, accessed December 2014 at http://pubs.water.usgs.gov/twri9A7/. 
Nagle, G.N., Fahey, T.J., Ritchie, J.C., and Woodbury, P.B., 2007, Variations in sediment sources and yields in the Finger Lakes and Catskills regions of New York: Hydrological Processes, v. 21, no. 6, p. 828-838, http://onlinelibrary.wiley.com/doi/10.1002/hyp.6611/pdf.

National Atmospheric Deposition Program, 2015, NTN data retrieval options: Champaign, Ill., National Atmospheric Deposition Program Office, Illinois State Water Survey, accessed June 19, 2015, at http://nadp.isws.illinois.edu/ NTN/ntnData.aspx.

Nestler, Angelika, Berglund, Michael, Accoe, Frederik, Duta, Steluta, Xue, Dongmei, Boeckx, Pascal, and Taylor, Philip, 2011, Isotopes for improved management of nitrate pollution in aqueous resources-Review of surface water field studies: Environmental Science and Pollution Research, v. 18 , no. 4, p. 519-533, https://doi.org/10.1007/s11356010-0422-z.

Pachepsky, Y.A., Guber, A.K., Shelton, D.R., and Hill, R.L., 2009, E. coli resuspension during an artificial high-flow event in a small first-order creek: Geophysical Research Abstracts, no. 11, EGU2009-9880.

Pachepsky, Y.A., and Shelton, D.R., 2011, Escherichia coli and fecal coliforms in freshwater and estuarine sediments: Critical Reviews in Environmental Science and Technology, v. 41, no. 12, p. 1067-1110, http://dx.doi.org/10.1080/10643380903392718.

Panno, S.V., Hackley, K.C., Kelly, W.R., and Hwang, H.H., 2006, Isotopic evidence of nitrate sources and denitrification in the Mississippi River, Illinois: Journal of Environmental Quality, v. 35, no. 2, p. 495-504, accessed August 2016 at https://doi.org/10.2134/jeq2005.0012.

Papanicolaou, A.N., Fox, J.F., and Marshall, John, 2003, Soil fingerprinting in the Palouse Basin, USA, using stable carbon and nitrogen isotopes: International Journal of Sediment Research, v. 18, no. 2, p. 278-284.

Patton, C.J., and Kryskalla, J.R., 2011, Colorimetric determination of nitrate plus nitrite in water by enzymatic reduction, automated discrete analyzer methods: U.S. Geological Survey Techniques and Methods, book 5, chap. B8, 34 p.

Patton, C.J., and Truitt, E.P., 1992, Methods of analysis by the U.S. Geological Survey National Water Quality Laboratory-Determination of the total phosphorus by a Kjeldahl digestion method and an automated colorimetric finish that includes dialysis: U.S. Geological Survey Open-File Report 92-146, 39 p. (Method ID: I-4610-91) [Also available at https://pubs.er.usgs.gov/publication/ofr92146.]
Patton, C.J., and Truitt, E.P., 2000, Methods of analysis by the U.S. Geological Survey National Water Quality Laboratory-Determination of ammonium plus organic nitrogen by a Kjeldahl digestion method and an automated photometric finish that includes digest cleanup by gas diffusion: U.S. Geological Survey Open-File Report 00-170, 31 p.

Phillips, J.M., Russell, M.A., and Walling, D.E., 2000, Time-integrated sampling of fluvial suspended sedimentA simple methodology for small catchments: Hydrological Processes, v. 14, no. 14, p. 2589-2602, https://doi. org/10.1002/1099-1085(20001015)14:14<2589::AIDHYP94>3.0.CO;2-D.

R Development Core Team, 2014, R-A language and environment for statistical computing, R Foundation for Statistical Computing, Vienna, Austria. [Also available at http://www.R-project.org.]

Rantz, S.E., and others, 1982, Measurement and computation of streamflow-vol. 2 - Computation and discharge: U.S. Geological Survey Water-Supply Paper 2175, v. 2, 631 p. [Also available at https://pubs.usgs.gov/wsp/wsp2175/pdf/ chapter10_vol2.pdf.]

Rao, C.R., 1965, Linear statistical inference and its applications: New York, John Wiley \& Sons, Inc., 522 p.

Révész, Kinga, Qi, Haiping, and Coplen, T.B., 2012, Determination of the $\delta^{15} \mathrm{~N}$ and $\delta^{13} \mathrm{C}$ of total nitrogen and carbon in solids; RSIL lab code 1832, chap. 5 of Stable isotope-ratio methods, sec. C of Révész, Kinga, and Coplen, T.B., eds., Methods of the Reston Stable Isotope Laboratory (slightly revised from version 1.1 released in 2007): U.S. Geological Survey Techniques and Methods, book 10, 31 p., available only online at http://pubs.usgs.gov/tm/2006/tm10c5/. (Supersedes versions 1.0 and 1.1 released in 2006 and 2007, respectively.)

Risley, John, Stonewall, Adam, and Haluska, Tana, 2008, Estimating flow-duration and low-flow frequency statistics for unregulated streams in Oregon: U.S. Geological Survey Scientific Investigations Report 2008-5126, 22 p.

Ruddy, B.C., Lorenz, D.L., and Mueller, D.K., 2006, Countylevel estimates of nutrient inputs to the land surface of the conterminous United States, 1982-2001: U.S. Geological Survey Scientific Investigations Report 2006-5012, 17 p.

Runkel, R.L., Crawford, C.G., and Cohn, T.A., 2004, Load estimator (LOADEST) - A FORTRAN program for estimating constituent loads in streams and rivers: U.S. Geological Survey Techniques and Methods, book 4, chap. A5, $69 \mathrm{p}$. 
Rus, D.L., Patton, C.J., Mueller, D.K., and Crawford, C.G., 2012, Assessing total nitrogen in surface-water samplesPrecision and bias of analytical and computational methods: U.S. Geological Survey Scientific Investigations Report 2012-5281, 38 p.

Russell, M.A., Walling, D.E., and Hodgkinson, R.A., 2000, Appraisal of a simple sampling device for collecting timeintegrated fluvial suspended sediment samples, in Proceedings of a symposium held at Waterloo, Canada, July 2000, The role of erosion and sediment transport in nutrient and contaminant transfer: International Asssociation of Hydrological Sciences, no. 263, p. 119-127.

Rutledge, A.T., 1998, Computer programs for describing the recession of ground-water discharge and for estimating mean ground-water recharge and discharge from streamflow records-Update: U.S. Geological Survey Water-Resources Investigations Report 98-4148, 43 p.

Sauer, V.B., 2002, Standards for the analysis and processing of surface-water data and information using electronic methods: U.S. Geological Survey Water-Resources Investigations Report 01-4044, 91 p.

Seurinck, Sylvie, Defoirdt, Tom, Verstraete, Willy, and Siciliano, S.D., 2005, Detection and quantification of the human-specific HF183 Bacteroides 16S rRNA genetic marker with real-time PCR for assessment of human fecal pollution in freshwater: Environmental Microbiology, v. 7, no. 2, p. 249-259, https://doi.org/10.1111/j.1462-2920.2004.00702.x.

Shapiro, S.S., and Wilk, M.B., 1965, An analysis of variance test for normality: Biometrika, v. 52, no. 3/4, p. 591-611.

Sigman, D.M., Casciotti, K.L., Andreani, M., Barford, C., Galanter, M., and Böhlke, J.K., 2001, A bacterial methods for the nitrogen isotopic analysis of nitrate in seawater and freshwater: Analytical Chemistry, v. 73, p. 4145-4153.

Silva, S.R., Ging, P.B., Lee, R.W., Ebbert, J.C., Tesoriero, A.J., and Inkpen, E.L., 2002, Forensic applications of nitrogen and oxygen isotopes in tracing nitrate sources in urban environments: Environmental Forensics, v. 3, no. 2, p. 125-130, http://doi.org/10.1006/enfo.2002.0086.

Sloto, R.A., Gellis, A.C., and Galeone, D.G., 2012, Total nitrogen and suspended-sediment loads and identification of suspended-sediment sources in the Laurel Hill Creek watershed, Somerset County, Pennsylvania, water years 2010-11: U.S. Geological Survey Scientific Investigations Report 2012-5250, 44 p., accessed July 2016 at http://pubs.usgs.gov/sir/2012/5250.

TIBCO, 2008, Spotfire S+ 8.1 for Windows: Somerville, Mass., TIBCO software release.
Turnipseed, D.P., and Sauer, V.B., 2010, Discharge measurements at gaging stations: U.S. Geological Survey Techniques and Methods, book 3, chap. A8, 87 p. [Also available at http://pubs.usgs.gov/tm/tm3-a 8/.]

University of Kentucky, 2012, Distribution of fertilizer sales in Kentucky-Annual report fertilizer year 2012: Lexington, Ky., University of Kentucky, College of Agriculture, accessed June 11, 2015, at http://www.rs.uky.edu/regulatory/fertilizer/tonnage/tonnage_reports/FY2012/2012Distrib utionYearlyReport.pdf.

U.S. Department of Agriculture, 1980, Soil survey of Christian County, Kentucky: U.S. Department of Agriculture, Soil Conservation Service, accessed June 11, 2015, at https://www.nrcs.usda.gov/Internet/FSE_MANUSCRIPTS/ kentucky/christianKY1980/crstKY1980.pdf.

U.S. Department of Agriculture, 1981, Land resource regions and major land resource areas of the United States, the Caribbean, and the Pacific Basin: U.S. Department of Agriculture Agricultural Handbook No. 296, accessed on June 11, 2015, at http://www.nrcs.usda.gov/wps/portal/nrcs/ detail/soils/survey/?cid=nrcs142p2_053624.

U.S. Department of Agriculture, 2012, County level data: National Agricultural Statistics Service, accessed April 7, 2017, at https://www.agcensus.usda.gov/Publications/2012/ Full_Report/Volume_1,_Chapter_2_County_Level/ Kentucky/.

U.S. Department of Agriculture, 2013, County estimates: National Agricultural Statistics Service, accessed July 26, 2015, at http://www.nass.usda.gov/Statistics_by_State/ Kentucky/Publications/County_Estimates/.

U.S. Environmental Protection Agency, 1986, Ambient water quality criteria for bacteria: Washington, D.C., U.S. Environmental Protection Agency, EPA 440/5-84-002, 60 p.

U.S. Environmental Protection Agency, 1999, Draft guidance for water quality-based decisions-The TMDL process: Washington, D.C., U.S. Environmental Protection Agency, EPA 841-D-99-001, 107 p.

U.S. Environmental Protection Agency, 2000, Ambient water quality criteria recommendations-Rivers and streams in nutrient ecoregion IX: Washington, D.C., U.S. Environmental Protection Agency, EPA 822-B-00-019, 33 p.

U.S. Environmental Protection Agency, 2003, Guidelines establishing test procedures for the analysis of pollutants; Analytical methods for biological pollutants in ambient water; Final rule, Part 136: U.S. Code of Federal Regulations, Title 40, vol. 68, no. 139, revised July 21, 2003, p. 43272-43283. 
U.S. Environmental Protection Agency, 2010, Method B-

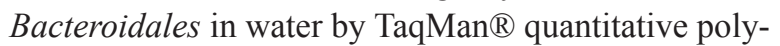
merase chain reaction (qPCR) assay: Washington, D.C., Office of Water, EPA-822-R-10-003.

U.S. Environmental Protection Agency, 2012, Discharge monitoring report (DMR) pollutant loading tool: Washington, D.C., accessed January 17, 2015, at https://cfpub.epa.gov/dmr/compare_dmr_tri_multiyr.cfm.

U.S. Environmental Protection Agency, 2015, National summary of impaired waters and TMDL information: Washington, D.C., accessed July 26, 2015, at https://iaspub.epa.gov/ waters10/attains_nation_cy.control?p_report_type $=\mathrm{T}$.

U.S. Geological Survey, variously dated, National field manual for the collection of water-quality data: U.S. Geological Survey Techniques of Water- Resources Investigations, book 9, chaps. A1-A4, https://pubs.water.usgs.gov/twri9A.

Van Metre, P.C., Frey, J.W., Musgrove, M., Nakagaki, N., Qi, S., Mahler, B.J., Wieczorek, M.E., and Button, D.T., 2016, High nitrate concentrations in some Midwest United States streams in 2013 after the 2012 drought: Journal of Environmental Quality, v. 45, no. 5., p. 1696-1704, accessed June 6, 2017, at https://www.ncbi.nlm.nih.gov/pubmed/27695770.

Venables, W.N., and Ripley, B.D., 2002, Modern applied statistics with S (4th ed.): New York, Springer, 495 p.

Wainer, Howard, 1976, Robust statistics-A survey and some prescriptions: Journal of Educational Statistics, v. 1, no. 4, p. 285-312.

Walling, D.E., 2005, Tracing suspended sediment sources in catchments and river systems: Science of the Total Environment, v. 344, no. 1-3, p. 159-184, http://dx.doi.org/10.1016/j.scitotenv.2005.02.011.

Walling, D.E., Collins, A.L., and Stroud, R.W., 2008, Tracing suspended sediment and particulate phosphorus sources in catchments: Journal of Hydrology, v. 350, no. 3-4, p. 274-289, http://dx.doi.org/10.1016/j.jhydrol.2007.10.047.

Walling, D.E., Owens, P.N., and Leeks, G.J.L., 1999, Fingerprinting suspended sediment sources in the catchment of the River Ouse, Yorkshire, U.K.: Hydrological Processes, v. 13, no. 7, p. 955-975.
Walling, D.E., Woodward, J.C., and Nicholas, A.P., 1993, A multi-parameter approach to fingerprinting suspendedsediment sources, in Peter, N.E., Hoehn, W., Leibundgut, Ch., Tase, N., and Walling, D.E., eds., Tracers in hydrology: International Association of Hydrological Sciences, no. 25, p. 329-338.

Weihs, C., Ligges, U., Luebke, K., and Raabe, N., 2005, Analyzing German business cycles, in Baier, D., and others, eds., Data analysis and decision support: Berlin, Springer, p. 335-343.

Western Kentucky University, 2015, Kentucky Mesonet: Bowling Green, Ky., accessed June 9, 2015, at http://kymesonet.org/.

Wilkinson, Jeremy, Kay, David, Wyer, Mark, and Jenkins, Alan, 2006, Processes driving the episodic flux of faecal indicator organisms in streams impacting on recreational and shellfish harvesting waters: Water Research, v. 40, no. 1, p. 153-161, http://dx.doi.org/10.1016/j.watres.2005.11.001.

Williamson, T.N., Christensen, V.G., Richardson, W.B., Frey, J.W., Gellis, A.C., Kieta, K.A., and Fitzpatrick, F.A., 2014, Stream sediment sources in Midwest agricultural basins with land retirement along channel: Journal of Environmental Quality, v. 43, no. 5, p. 1624-1634, https://doi.org/10.2134/jeq2013.12.0521.

Woods, A.J., Omernik, J.M., Martin, W.H., Pond, G.J., Andrews, W.M., Call, S.M., Comstock, J.A., and Taylor, D.D., 2002, Ecoregions of Kentucky (color poster with map, descriptive text, summary tables, and photographs): U.S. Geological Survey poster, scale 1:1,000,000.

Xue, Dongmei, Botte, Jorin, De Baets, Bernard, Accoe, Frederik, Nestler, Angelika, Taylor, Philip, Van Cleemput, Oswald, Berglund, Michael, and Boeckx, Pascal, 2009, Present limitations and future prospects of stable isotope methods for nitrate source identification in surface- and groundwater: Water Research, v. 43, no. 5, p. 1159-1170, http://dx.doi.org/10.1016/j.watres.2008.12.048.

Yue, F.J., Li, S.L., Liu, C.Q., Lang, Y.C., and Ding, Hu, 2015, Sources and transport of nitrate constrained by the isotopic technique in a karst catchment-An example from Southwest China: Hydrological Processes, v. 29, no. 8, p. 18831893, https://doi.org/10.1002/hyp.10302. 
For more information about this report, contact: Director, Indiana-Kentucky Water Science Center U.S. Geological Survey

9818 Bluegrass Parkway

Louisville, KY 40299

dc_ky@usgs.gov

or visit our website at

https://ky.water.usgs.gov/

Publishing support provided by the

Madison and Pembroke Publishing Service Centers 


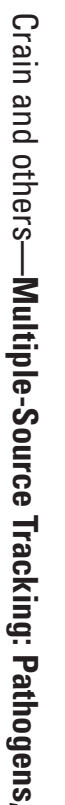

䆣.

言

弯

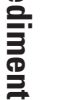

듷

$\overline{\bar{F}}$

गج.

.

产

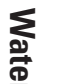

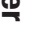

赵

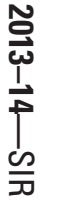

$\widetilde{\widetilde{N}}$

蛒 